\title{
LESSONS LEARNED FROM 20 NON-RESIDENTIAL BUILDING RENOVATIONS
}

IEA SHC Report: T.47.A.1

Date 05.02.2015
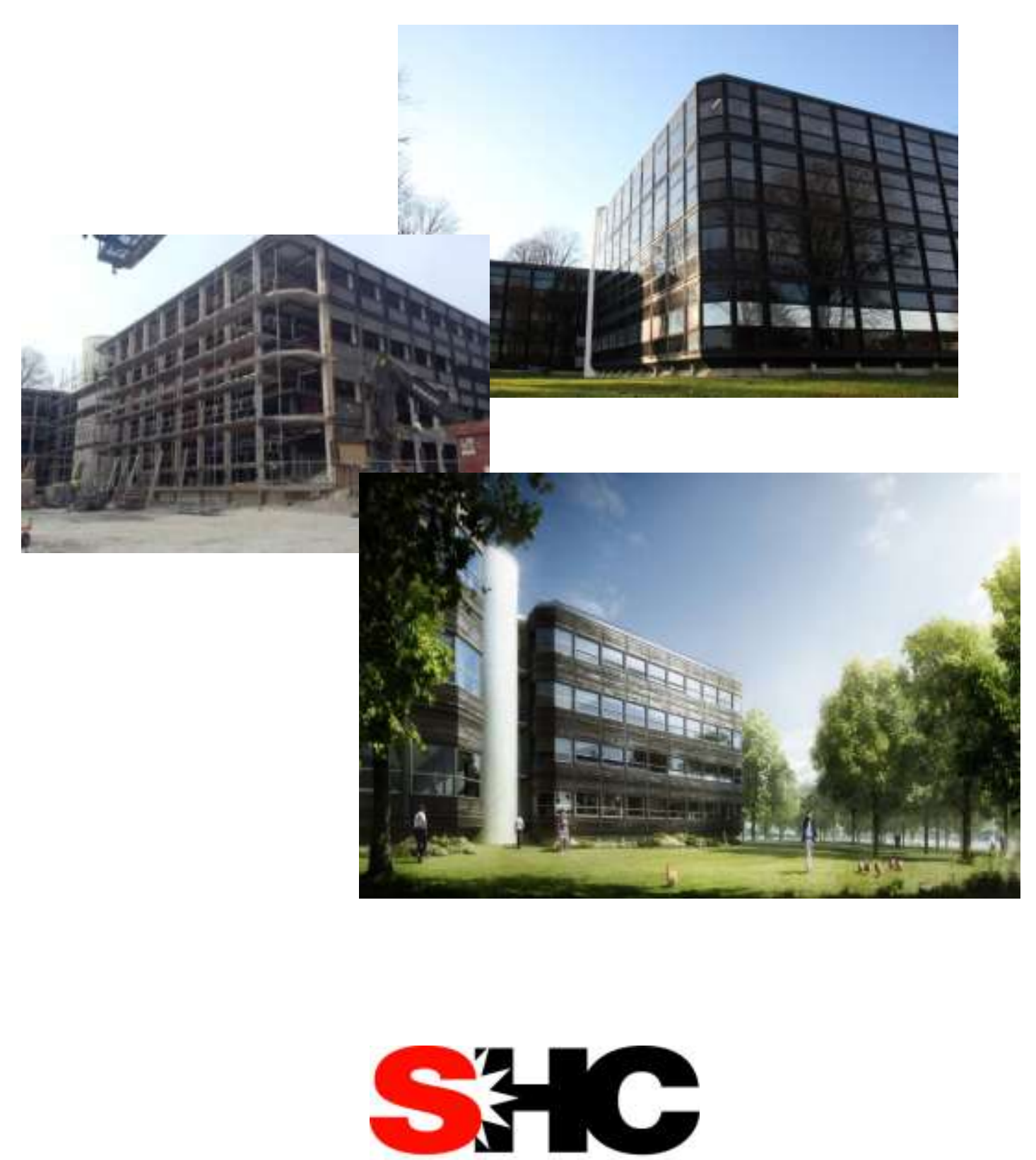

SOLAR HEATING \& COOLING PROGRAMME INTERNATIONAL ENERGY AGENCY 
Picture front page: Powerhouse Kjørbo, Norway

\section{IEA SHC Report: T.47.A.1}

\section{Authors:}

Fritjof Salvesen and Mari Lyseid Authen, Asplan Viak AS, Norway

\section{Co-authors:}

\begin{tabular}{|c|c|}
\hline Claudia Dankl & Austrian Society for Environment and Technology, Austria \\
\hline Thomas Mach & Graz University of Technology Austria \\
\hline Sophie Grünewald & Graz University of Technology, Austria \\
\hline Sophie Trachte & Architecture et Climat - University of Louvain La Neuve, Belgium \\
\hline Doreen Kalz & Fraunhofer - Inst. Solar Energy Systems, Germany \\
\hline Kirsten Engelund Thomsen & Danish Building Research Institute, Aalborg University Copenhagen, Denmark \\
\hline Jørgen Rose & Danish Building Research Institute, Aalborg University Copenhagen, Denmark \\
\hline Ezilda Constanzo & ENEA, Italy \\
\hline Giorgio Pansa & Politecnico di Milano - ABC Department, Italy \\
\hline Arne Førland Larsen & Asplan Viak AS, Norway \\
\hline Anna Svensson & SINTEF Building and Infrastructure, Norway \\
\hline Mads Mysen & SINTEF Building and Infrastructure, Norway \\
\hline Michael Klinski & SINTEF Building and Infrastructure, Norway \\
\hline
\end{tabular}

Notice:

The Solar Heating and Cooling Programme, also known as the Programme to Develop and Test Solar Heating and Cooling Systems, functions within a framework created by the International Energy (IEA). Views, findings and publications of the Solar Heating and Cooling Programme do not necessarily represent the views of the IEA Secretariat or of all its individual member countries. 


\section{Content}

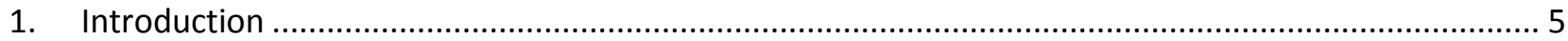

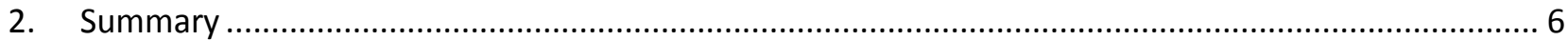

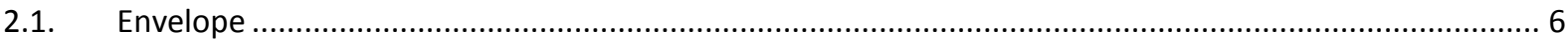

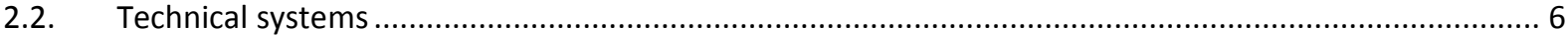

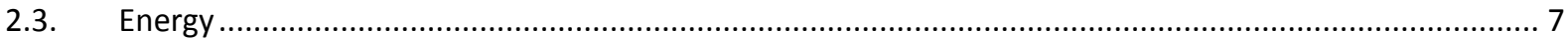

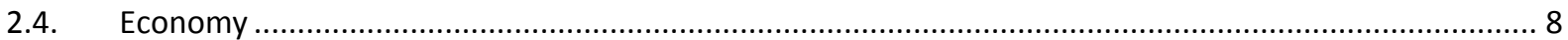

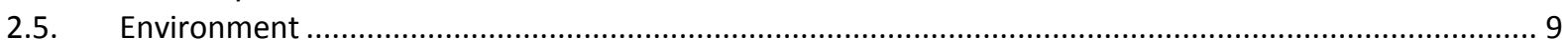

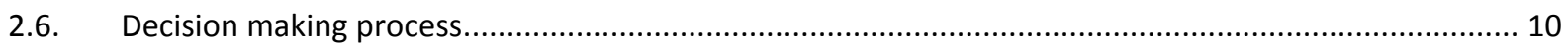

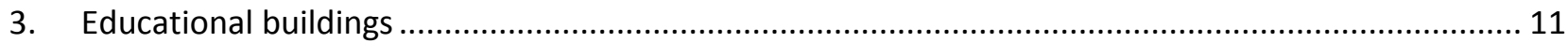

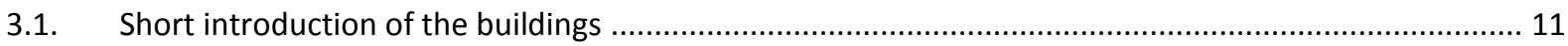

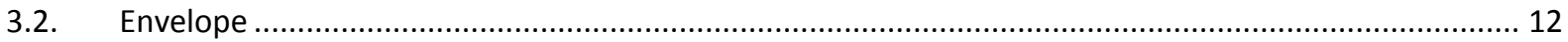

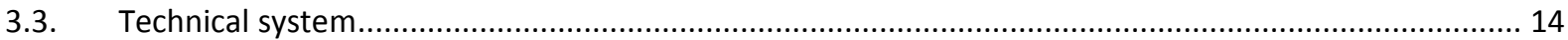

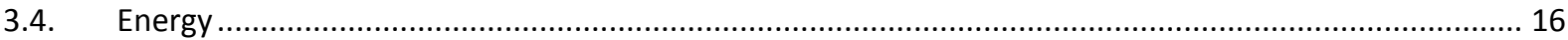

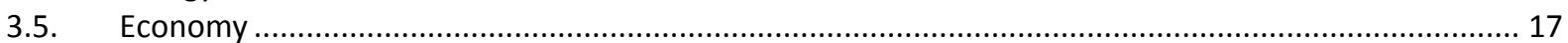

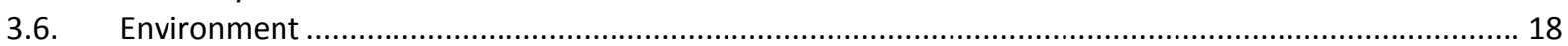

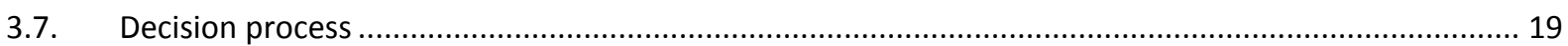

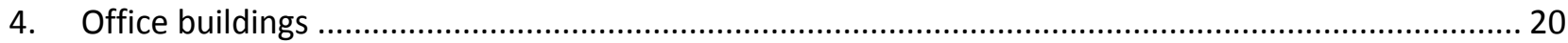

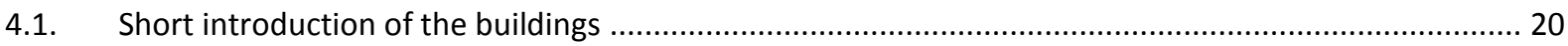

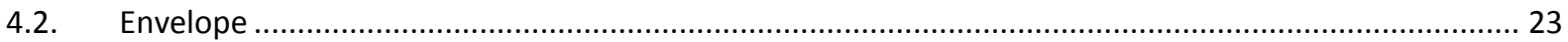

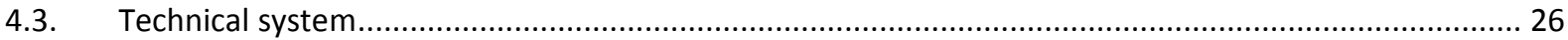

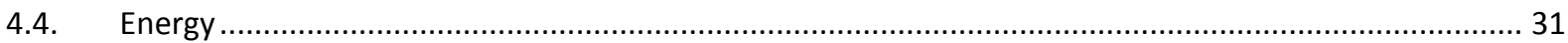

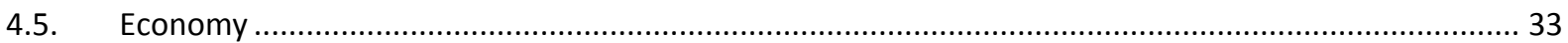

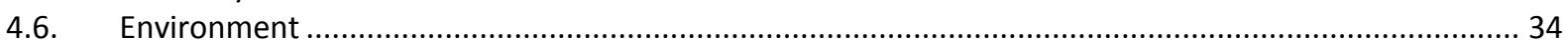

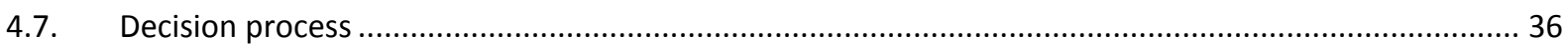

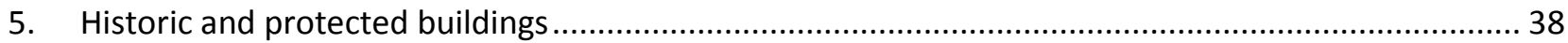

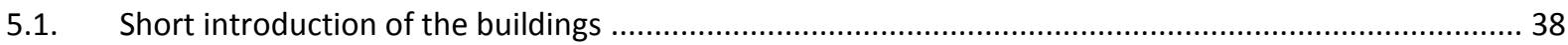

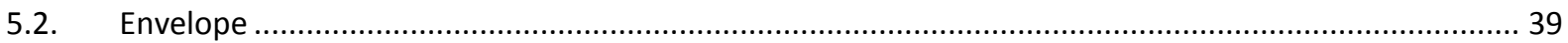

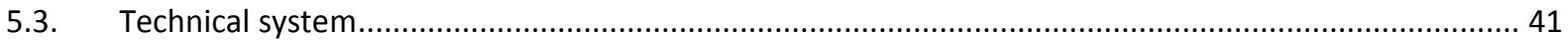

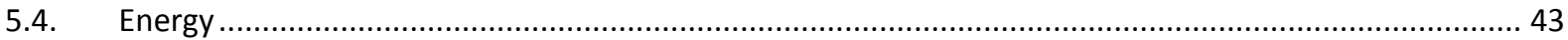

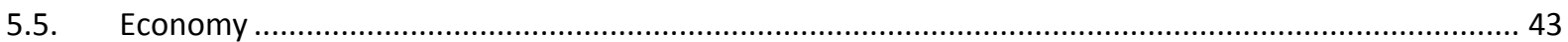

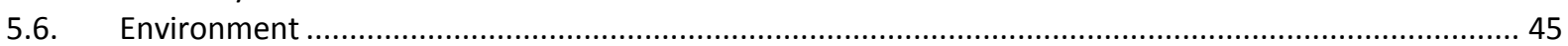

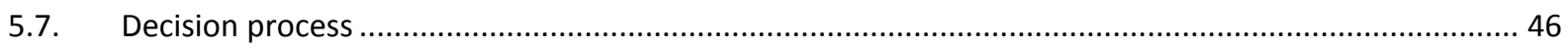

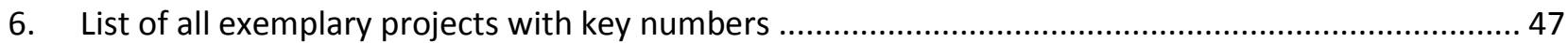

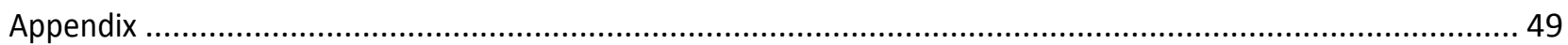

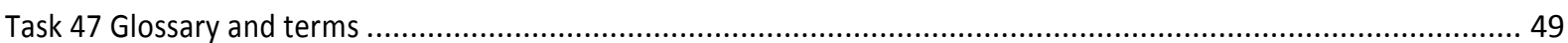




\section{IEA Solar Heating and Cooling Programme}

The Solar Heating and Cooling Programme was founded in 1977 as one of the first multilateral technology initiatives ("Implementing Agreements") of the International Energy Agency. Its mission is "to enhance collective knowledge and application of solar heating and cooling through international collaboration to reach the goal set in the vision of solar thermal energy meeting $50 \%$ of low temperature heating and cooling demand by 2050.

The member countries of the Programme collaborate on projects (referred to as "Tasks") in the field of research, development, demonstration (RD\&D), and test methods for solar thermal energy and solar buildings.

A total of 53 such projects have been initiated to-date, 39 of which have been completed. Research topics include:

A Solar Space Heating and Water Heating (Tasks 14, 19, 26, 44)

A Solar Cooling (Tasks 25, 38, 48, 53)

A Solar Heat or Industrial or Agricultural Processes (Tasks 29, 33, 49)

A Solar District Heating (Tasks 7, 45)

A Solar Buildings/Architecture/Urban Planning (Tasks 8, 11, 12, 13, 20, 22, 23, 28, 37, 40, 41, 47, 51, 52)

A Solar Thermal \& PV (Tasks 16, 35)

A Daylighting/Lighting (Tasks 21, 31, 50)

A Materials/Components for Solar Heating and Cooling (Tasks 2, 3, 6, 10, 18, 27, 39)

A Standards, Certification, and Test Methods (Tasks 14, 24, 34, 43)

A Resource Assessment (Tasks 1, 4, 5, 9, 17, 36, 46)

A Storage of Solar Heat (Tasks 7, 32, 42)

In addition to the project work, there are special activities:

$>$ SHC International Conference on Solar Heating and Cooling for Buildings and Industry

$>$ Solar Heat Worldwide - annual statistics publication

> Memorandum of Understanding with solar thermal trade organizations

$>$ Workshops and conferences

\section{Country Members}

$\begin{array}{lll}\text { Australia } & \text { Germany } & \text { Singapore } \\ \text { Austria } & \text { Finland } & \text { South Africa } \\ \text { Belgium } & \text { France } & \text { Spain } \\ \text { China } & \text { Italy } & \text { Sweden } \\ \text { Canada } & \text { Mexico } & \text { Switzerland } \\ \text { Denmark } & \text { Netherlands } & \text { Turkey } \\ \text { European Commission } & \text { Norway } & \text { United Kingdom } \\ & \text { Portugal } & \text { United States }\end{array}$

Sponsor Members

European Copper Institute Gulf Organization for Research and Development

ECREEE

RCREE

\section{Further information:}

For up to date information on the IEA SHC work, including many free publications, please visit www.ieashc.org. 


\section{Introduction}

Buildings are responsible for up to $35 \%$ of the total energy consumption in many of the IEA participating countries. The EU Parliament approved in April 2009 a recommendation that member states have to set intermediate goals for existing buildings to fix a minimum percentage of buildings to be net zero energy by 2015 and 2020 .

A few exemplary non-residential renovation projects have demonstrated that total primary energy consumption can be drastically reduced together with improvements of the indoor climate. Because most property owners are not even aware that such savings are possible, they set too conservative energy targets. Buildings renovated to mediocre performance can be a lost opportunity for decades.

The objectives of this Task are to develop a solid knowledge base on how to renovate non-residential buildings towards the NZEB standards (Net-Zero Energy Buildings) in a sustainable and cost-efficient way and to identify the most important market and policy issues as well as marketing strategies for such renovations.

The Task 47 is divided into four subtasks:

- Subtask A: Advanced Exemplary Projects - Information Collection \& Brief Analysis

- Subtask B: Market and Policy issues and Marketing Strategies

- Subtask C: Assessment of Technical Solutions and Operational Management

- Subtask D: Environmental and Health Impact Assessment

More Task 47 information can be found at http://task47.iea-shc.org/

Task 47 started in January 2011 by analyzing highly successful renovations as a basis for the development of innovative concepts for the most important market segments. This report summarizes the findings from these 20 exemplary renovation projects. All projects are described in eight-page brochures, which are available for download from http://task47.iea-shc.org/publications

The buildings are split into three categories:

- Educational buildings

- Office buildings

- Historic and protected buildings

The Task 47 experts also developed a list of relevant terms and definitions. The list is based on international and national definitions and is shown in the Appendix.

\begin{tabular}{|c|l|}
\hline \multicolumn{2}{|l|}{ Exemplary buildings in this report } \\
\hline AT & School in Schwanenstadt \\
\hline AT & ASO 4 Karlhofschule Linz \\
\hline AT & Administration Building Bruck/Mur \\
\hline AT & Kaiserstrasse 7, Vienna \\
\hline AT & Franciscan Monastery \\
\hline BE & Riva Bella School \\
\hline DE & Office and Workshop Fraunhofer ISE \\
\hline DE & Printing workshop and office building \\
\hline DE & TU Vienna Plus Energy \\
\hline DK & Kindergarten Vejtoften \\
\hline DK & Office Building Roskilde \\
\hline DK & Rockwool office building \\
\hline DK & Osram Culture Centre \\
\hline IT & School of Cesena \\
\hline IT & Schüco Headquarter \\
\hline NO & Tax Directorate Office Building \\
\hline NO & Powerhouse Kjørbo \\
\hline NO & Solbråveien office Centre \\
\hline NO & NVE office building \\
\hline NO & Kampen School \\
\hline
\end{tabular}




\section{Summary}

This chapter summarizes the findings from 20 exemplary renovation projects. The buildings are divided into three categories; educational buildings, office buildings and historic \& protected buildings. In this summary chapter, the key findings from all the buildings are described. More detailed information for each building category,is presented under the respective chapters. Each building is described in the brochures which can be downloaded from http://task47.iea-shc.org/publications

\subsection{Envelope}

Figure 1 shows the reduction of the insulation levels in building envelopes.

The figure shows the average $\mathrm{U}$-values $\left(\mathrm{W} / \mathrm{m}^{2} \mathrm{~K}\right)$ for the buildings before and after the renovation. The black lines show the variation in $\mathrm{U}$-values.

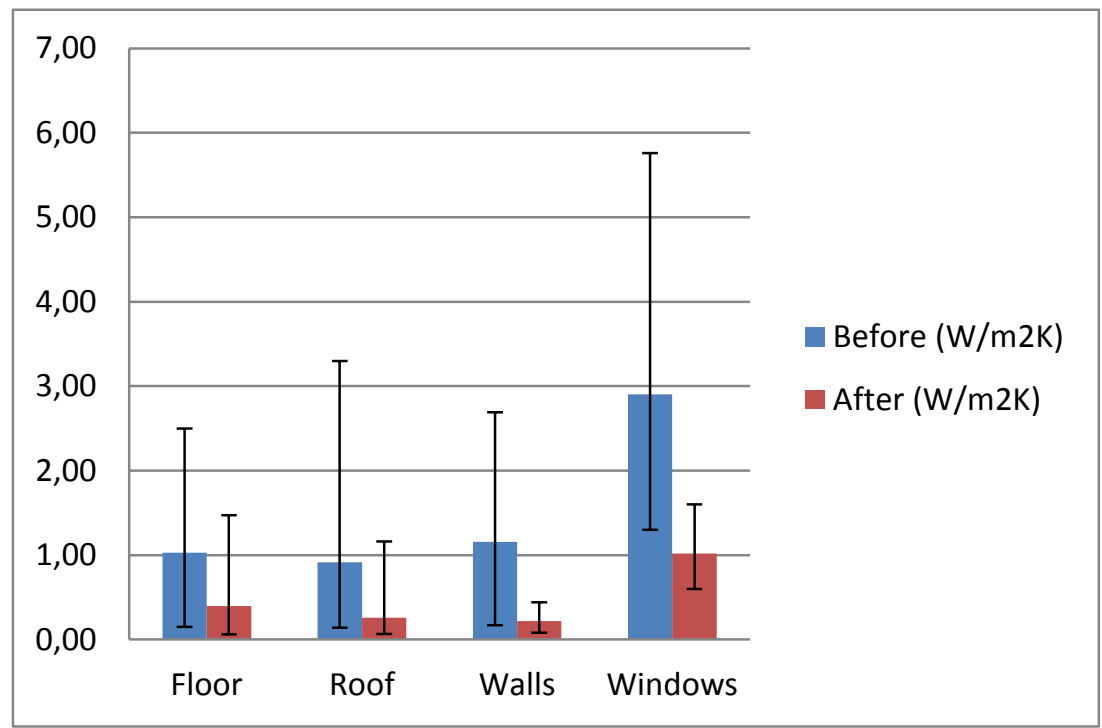

Figure 1 Average and $\min$ and max $\mathrm{U}$-values $(\mathrm{W} / \mathrm{m} 2 \mathrm{~K})$ for all buildings
The smallest absolute and relative improvements are in the floors, with a reduction in $\mathrm{U}$ values of $58 \%$. This is partly because of the historic buildings with no changes in the $U$-values of the floors. Also for the office buildings, the lowest absolute improvement was in the floors. This is the most difficult building component to improve, due to restriction in floor height. In one case, vacuum insulation was used.

The best absolute value improvements are in the windows. This indicates that most of the buildings had old single- or doublelayer windows, and these were replaced by triple glazing, with high quality window frames. All projects except for one have upgraded all or parts of the windows.

The walls and the roof have the greatest relative change in U-value. To reduce the infiltration is also a focus area in the renovation process, and airtightness of $0.2 \mathrm{~h}^{-1}$ has been achieved in projects. This value refers to a Blowerdoor test with $50 \mathrm{~Pa}$ over-/under pressure.

\subsection{Technical systems}

New technical systems were a major part of most of the renovations. Eleven out of twenty projects included solar energy as a part of their upgraded energy systems. PV (photovoltaic) systems have been installed in nine projects, total of $1,374 \mathrm{~kW}_{\mathrm{p}}$. Five of the projects have solar heating systems installed with a total area of $456 \mathrm{~m}^{2}$. 
Figure 2 shows that PV is the most common renewable energy source installed in these buildings. Six

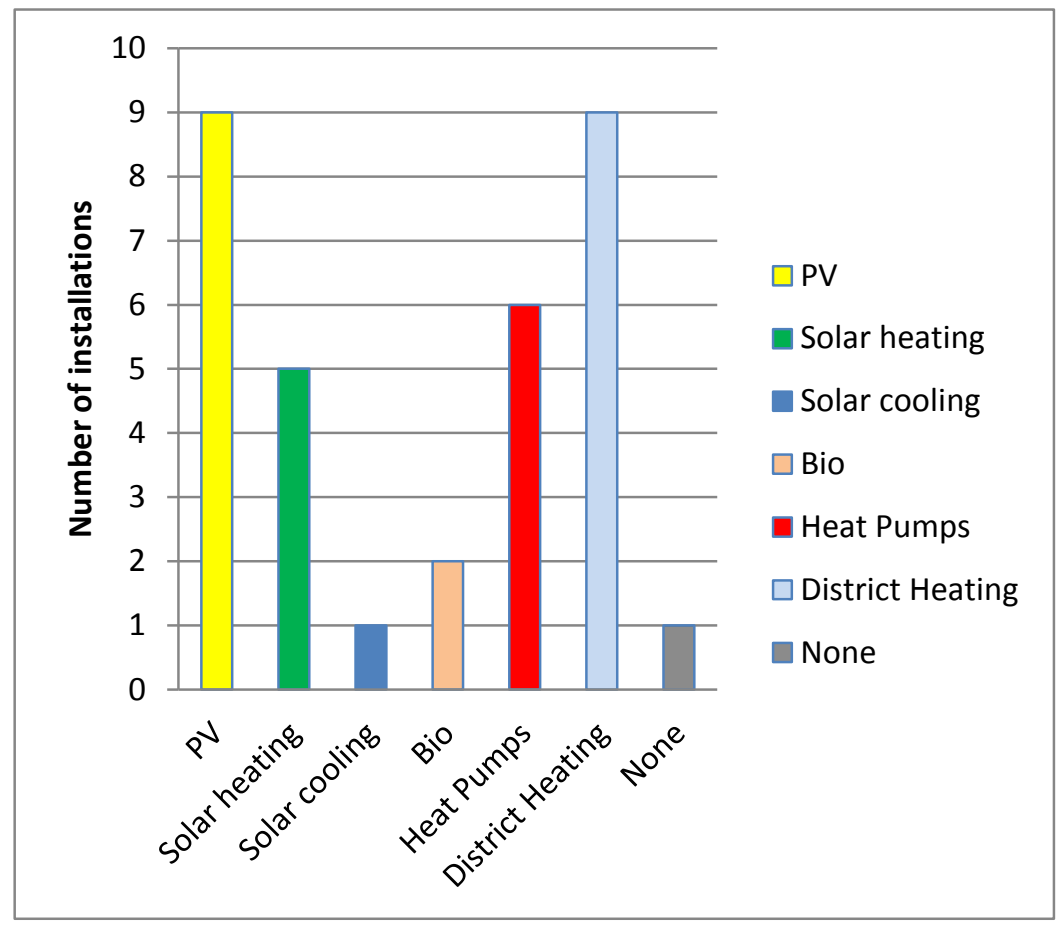

Figure 2 Renewable energy systems buildings include heat pumps and solar heating has been installed in five buildings. The remaining heat demand is covered by different energy sources such as bioenergy, condensing boiler and district heating. One of the listed buildings does not use any renewable energy.

For the presented buildings, PV seems to be more interesting for the building owner than solar thermal installations. One obvious reason is that most buildings are offices with limited domestic hot water use and low heat demand. One exception is a Monastery, which includes a system with $360 \mathrm{~m}^{2}$ of building-integrated solar collectors covering $20 \%$ of the space and water heating demand.

All the buildings have an improved ventilation system. In two of the buildings, the existing ducts have been reused, but modified. Several buildings have demand-controlled ventilation, often in combination with natural ventilation during the time of the year when this is possible. It is documented that the pupils in one of the school buildings showed significant improvement in the concentration test scores, and health and well-being questionnaires, after an upgrade of the ventilation system.

Limited mechanical cooling is needed, cooling demand is mostly covered by nighttime ventilation or free cooling from wells designed for ground coupled heat pumps. At least one of the buildings has a very good experience using the wells for cooling. Even during a very warm summer, the free cooling from the wells was enough to maintain a good indoor temperature.

Almost all buildings are focusing on better lighting system. Some have improved the utilization of daylight; some have installed energy efficient lights and/or installed movement sensors to save energy.

\subsection{Energy}

Four of the buildings lack information about the energy use before the renovation and these buildings are not included in the energy statistics. The remaining 16 projects have saved on average $67 \%$ of energy. Two of the office buildings have saved $90 \%$ of energy through energy efficiency measures. The educational buildings have an average energy saving of $71 \%$ and the office buildings - $77 \%$ savings. The historic buildings have saved $48 \%$ of energy. This may be due to restrictions concerning changes of the building facades. 
Figure 3 summarizes the energy demand after renovation. The dotted red line shows the target value for

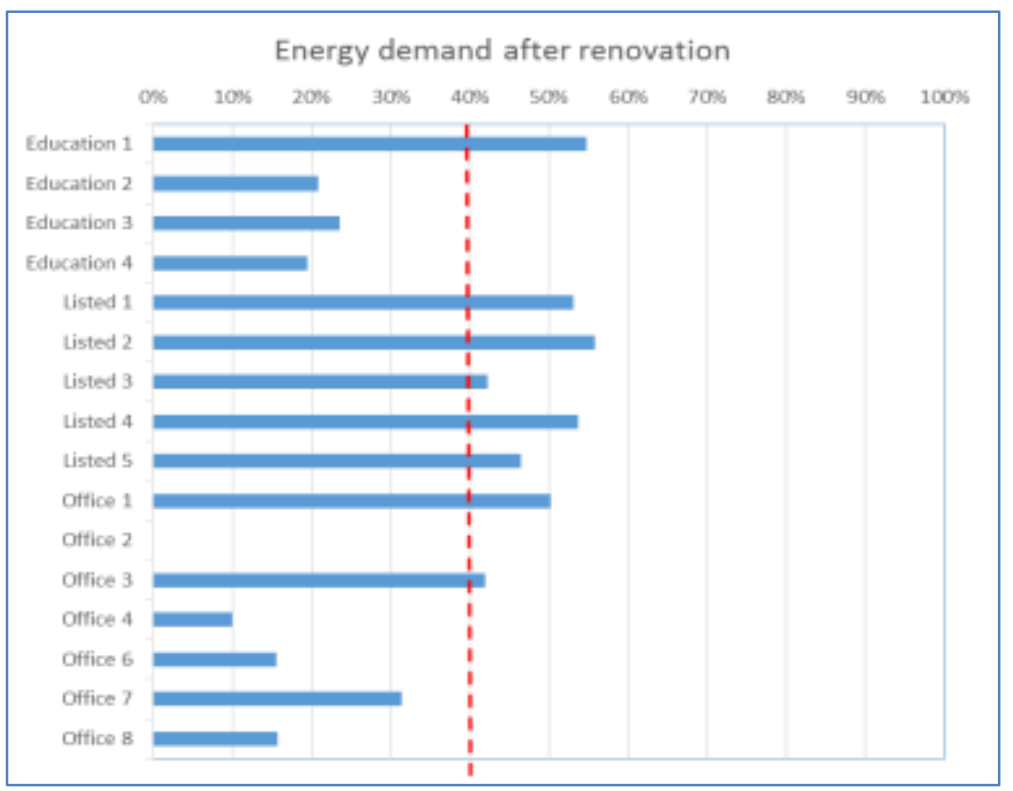

Figure 3 Percentage of energy demand after renovation
Task 47 projects. It should be noted that the energy numbers are not directly comparable due to different standards for calculations and reporting among the participating countries. Therefore, the savings are given as a percentage instead of actual energy numbers.

The Office 2 building is a plus-energy building, and the need for purchased energy after renovation is zero.

One of the educational buildings has a higher demand than the target value, however this building was nevertheless included as it showed a very low cost of renovation. It can also be seen that

it is difficult to reach the $60 \%$ reduction level for historic/listed buildings. In many cases it is not possible to change façade and/or windows, which significantly limits the energy saving potential.

One main conclusion is that in all building types, large energy savings are possible.

\subsection{Economy}

It is difficult to judge the renovation costs based on the 20 exemplary projects. Some projects do not have available cost data at all. If costs are available, they are often not comparable for the different projects; some include all the costs for the renovation and others are limited to the extra costs for energy efficiency

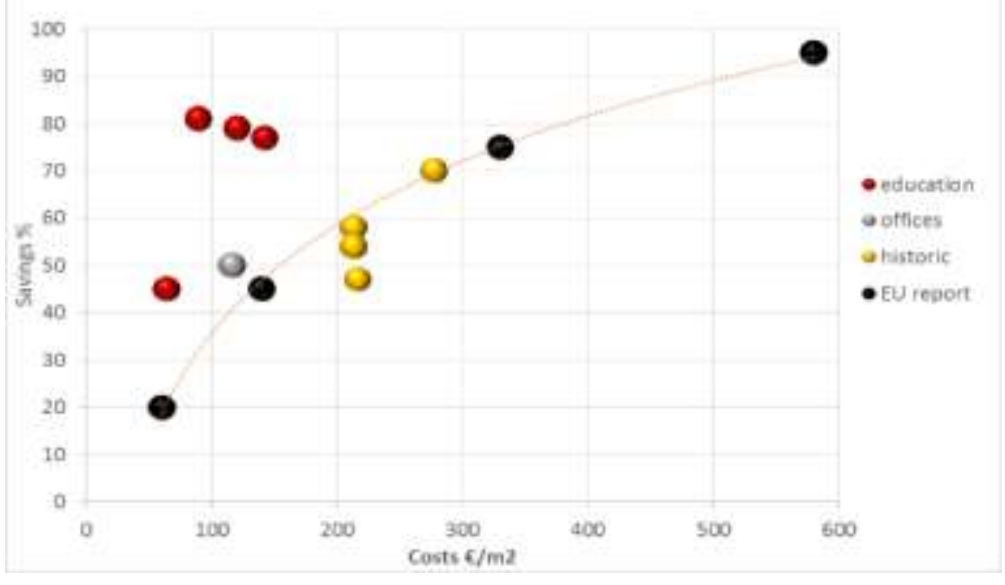

Figure 4 Savings and costs of energy efficiency measures. EU-report: "The energy efficiency investment potential for the buildings Environment; ECORYS/ECN Nov.2012" measures. Others again are a mix of these.

Figures 4 and 5 show savings versus costs. In the first diagram, the costs are limited to the energy efficiency measures and the second diagram shows the total renovation cost.

To compare the costs, the figure also includes values given in the EU-report "The Energy Efficiency Investment Potential for the Buildings Environment; CIRYS/ECN 7.Nov. 2012". 


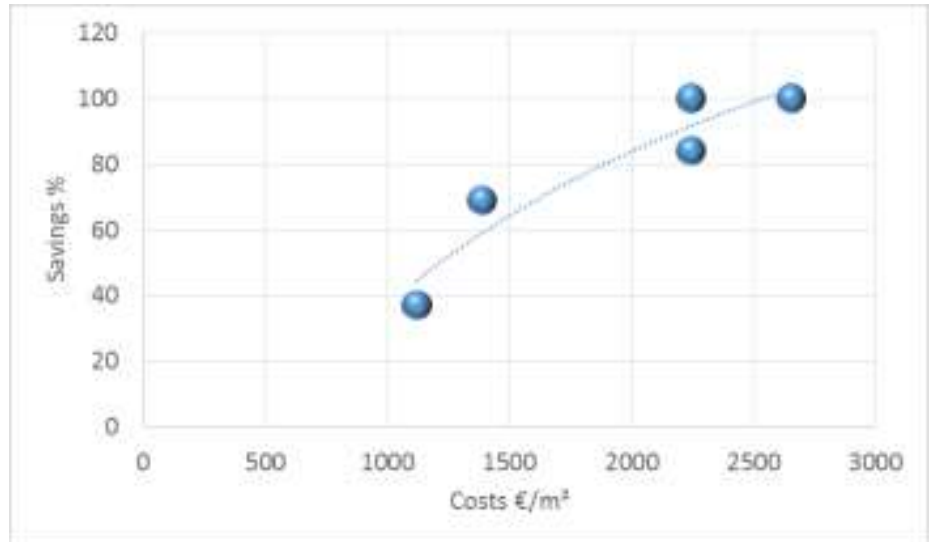

Figure 5 Savings vs total renovation costs for office buildings
Figure 5 shows savings versus the total cost of renovation for office buildings. The correlation to a logarithmic trend line is better than the previous figure. However, the number of renovation projects is too limited to have a significant statement.

Based on the 20 renovation projects, it does not seems possible to draw a significant relation between energy savings and renovation costs.

For most of the projects with cost information available, costs for energy saving measures are in the range of 70 to $210 € / \mathrm{m}^{2}$ with the corresponding energy savings of $45-60 \%$ of energy consumption.

\subsection{Environment}

Most of the renovation projects have focused on other environmental qualities than energy, as improved indoor climate, environmental friendly material use and some buildings have been evaluated by environmental classification systems.

Six of the buildings have been environmentally classified; three of the buildings have had a focus on environmentally friendly materials. Several of the buildings have accounted for an improvement in the indoor environment. Only one building have complains about the indoor temperature after the renovation.

Some of the buildings are classified according to national classification systems:

- BREEAM-NOR (UK/Norway): one listed building has obtained Very Good, and another office building reached the highest possible: Outstanding. This is the first renovated office building in the world reaching this classification level.

- EEC-ECO-Life certificate (Denmark).

- Total-Quality-Building (TQB) (Austria), three buildings have received the TQB-certificate.

- One office building has achieved the climate protection certificate "klima:aktiv Gold" (Austria).

- Indoor climate classification system (Germany); class A achieved for one office building.

Several projects report on a high degree of reuse of building materials and recycling of construction waste. In one project, more than $90 \%$ of the construction waste is reused or recycled. Other measures with regard to materials:

- Special focus on low emission materials;

- Materials with the lowest possible embodied energy;

- Extended use of ecological materials, performed LCA analysis ; 
Minimum $30 \%$ recycled aluminum and 50\%-recycled steel was used. Other environmental measurers:

- Water saving sanitary equipment;

- Several measures to improve the acoustic indoor climate;

- The lighting quality is improved with increased use of daylight and LED;

- Automatic control systems for the electric lighting based on daylight levels in the building;

- The indoor climate has improved, and a more stable and better indoor environment is achieved due to better temperature control, $\mathrm{CO}_{2}$-levels and lighting quality;

- Environmentally certified products have been used in interior and furniture.

\subsection{Decision making process}

The demonstration projects show that the typical timeframe from the initial idea of the renovation to a completed renovation will be $2-4$ years. However, there are examples showing that this period can vary significantly.

For many of the projects, the main incentives for the renovation were to reduce energy consumption and improve indoor climate. During the early phase of the planning process, the ambitions towards more energy efficient buildings have changed due to several reasons:

- A government call for sustainable renovation demonstration projects.

- Through a process with building owner and users, the ambition was increased to energy label A / Passive house standard.

- The owner of the building wanted to renew the expression of the building to better suit the company's green profile.

- The possibility to serve as an exemplary case project and to use it as an example and inspiration in the local community became more important during the process.

Sometimes there is some skepticism expressed to new solutions. In one school renovation project, many of the parents had prejudices against mechanical ventilation. This was solved by excursions to other schools as well as one year testing in one prototype classroom at the school. Skepticism towards Passive House Standards has been expressed in some cases.

Some renovations have had very high ambitions from the early start. In these projects, the focus during the design process has been on energy targets, and a multidisciplinary team of experts from research, consultancy, architects, contractor, tenants and owner was established and carried out a true "Integrated Design Process".

For a municipality who also owns 26 other kindergartens, it was decided that instead of making minor energy renovations in all 27 institutions, it was more cost efficient to make more energy ambitious renovations in a few buildings at a time.

In at least one of the office buildings, the tenants have accepted a new rent, which also includes the reduced costs for the expected energy savings. In this way, the building owner can share the renovation costs with the tenant. 


\section{Educational buildings}

Six of the projects are in the category educational buildings. One of these buildings are also categorized as a "Historic and protected building".

\subsection{Short introduction of the buildings}

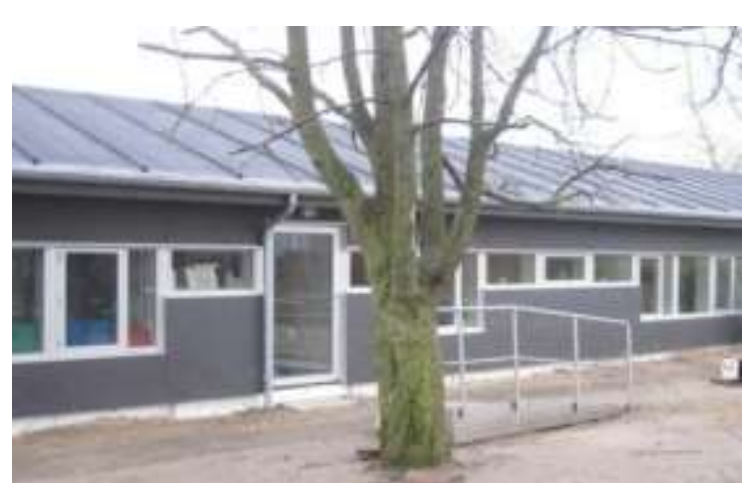

\section{Kindergarten Vejtoften in Høje Taastrup (DK)}

The kindergarten was built in 1971 and the energy renovation was finished in 2010. The building had no previous energy renovations. This is one out of 27 kindergartens in the municipality, which will undergo an extensive energy renovation. The total floor area is $350 \mathrm{~m}^{2}$ with 50 children located in three different rooms. Special features of the renovation: insulation of thermal envelope; new windows with three layers of glass; new ventilation system with higher efficiency and heat recovery.

\section{School in Cesena (IT)}

The primary school is from 1960's with a floor area of $6,420 \mathrm{~m}^{2}$. The objective of the renovation is to reduce heating and total energy consumption as well as improve indoor comfort. The energy renovation was carried out ensuring the continuity of school activities. Implemented measures addressed the following components/systems: the building envelope, heating system, PV plant, controlled mechanical ventilation in classrooms, remote Building Energy Management Systems (BEMS), external shading for thermal and daylighting control. Special focus on limited additional costs.
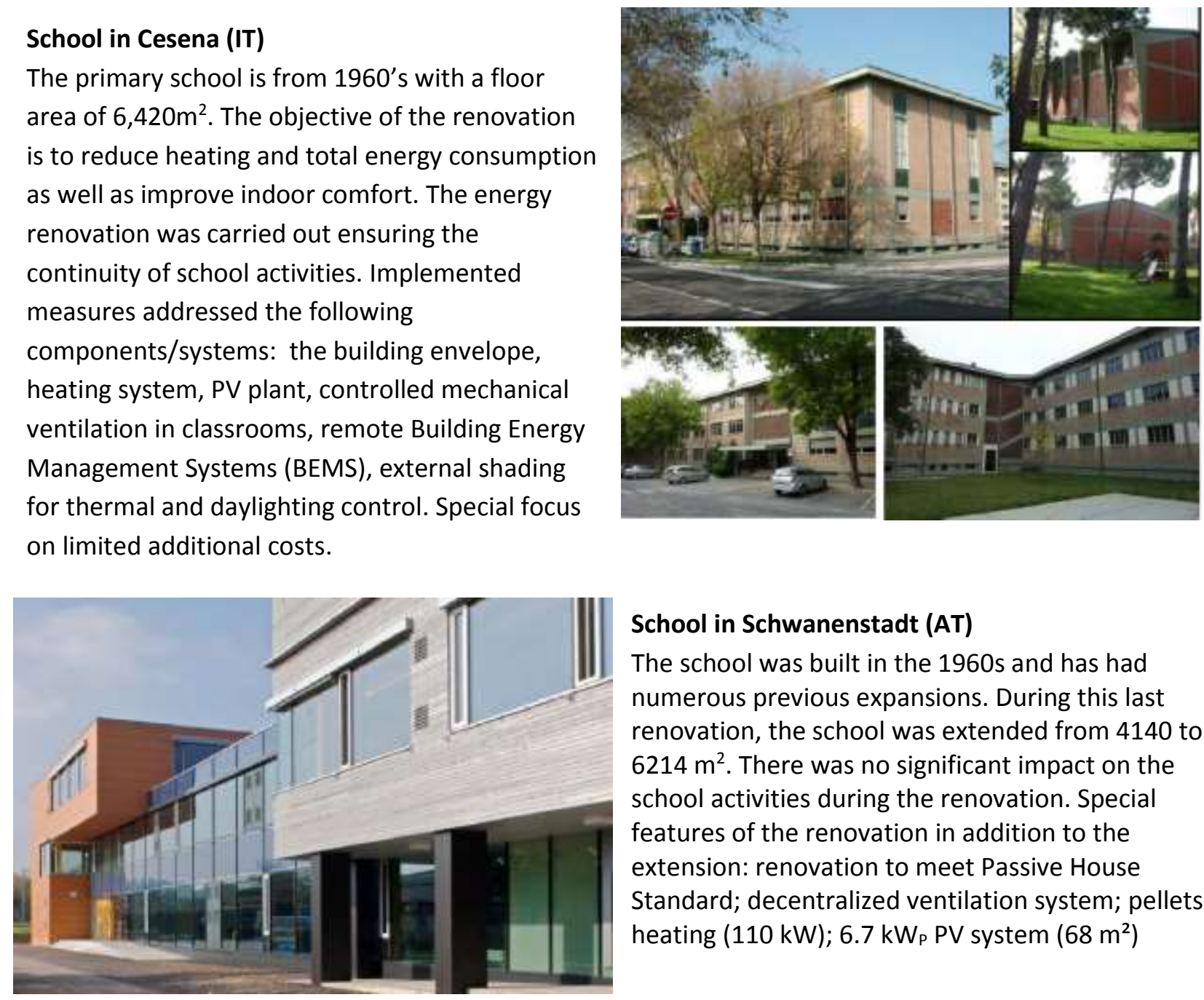

\section{School in Schwanenstadt (AT)}

The school was built in the 1960s and has had numerous previous expansions. During this last renovation, the school was extended from 4140 to $6214 \mathrm{~m}^{2}$. There was no significant impact on the school activities during the renovation. Special features of the renovation in addition to the extension: renovation to meet Passive House Standard; decentralized ventilation system; pellets heating (110 kW); $6.7 \mathrm{~kW}$ P PV system (68 $\left.\mathrm{m}^{2}\right)$ 


\section{The Riva Bella School (BE)}

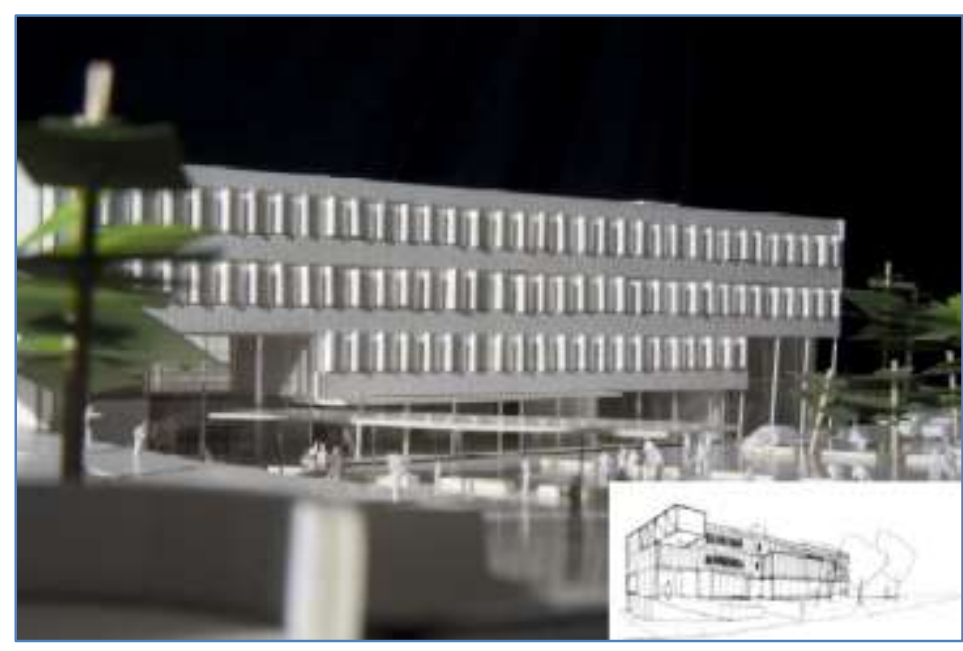

transforming; low energy renovation; extremely low budget.
The Royal Atheneum Riva Bella (BraineI'Alleud) forms a campus of various buildings. The renovated building "BSP" is a semi-prefabricated building, east-west oriented. The building has been unoccupied for the last 15 years due to incompliance with fire safety regulations and presence of asbestos. The building, $4500 \mathrm{~m}^{2}$, was renovated on an extremely low budget. Special features of the renovation: major refurbishment with conservation of the metallic structure; specific goal: renew -make new by

\section{ASO4 Karlhofschule (AT)}

The fifty-year-old school building was adapted and expanded to comply with the state-of-the-art educational requirements such as supervision in the afternoon or progressive education. Timber floors were added to the building because of bad statics in the existing structure, the existing floors were restructured and the access to the building has been considerably improved. The building was renovated to passive house standard and has a useable floor area of $2,000 \mathrm{~m}^{2}$. A solar thermal system integrated into the building envelope helps to provide hot water for the building. Natural nighttime ventilation during the summer period. The project has been awarded the Austrian State Prize for Architecture and Sustainability 2012.

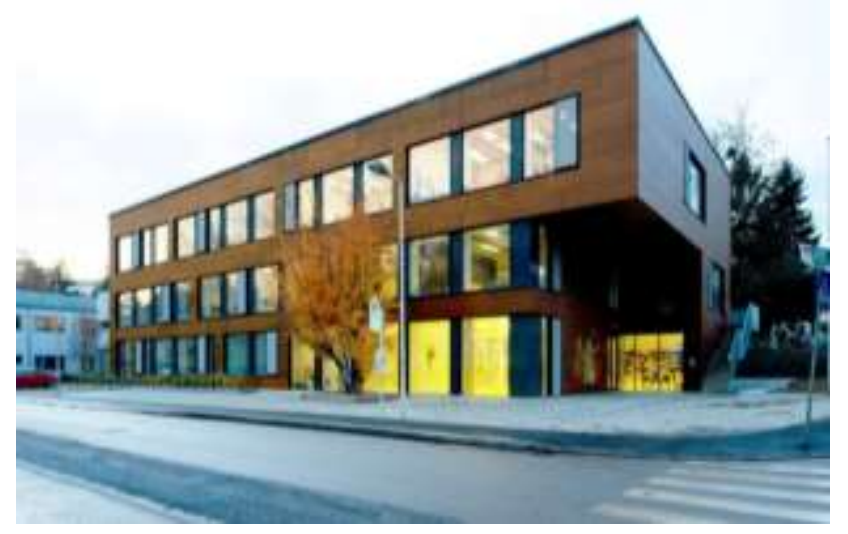

\section{Kampen School}

The school is also a listed historic building. More information about the school can be found in the chapter "Historic and protected buildings".

\subsection{Envelope}

Figure 6 shows the average $U$ - values for the buildings before and after the renovations. The lines show the variation in $\mathrm{U}$ - values.

One of the buildings, ASO4 Karlhofschule, has no measures for the building envelope. This building is not included in the figure. 


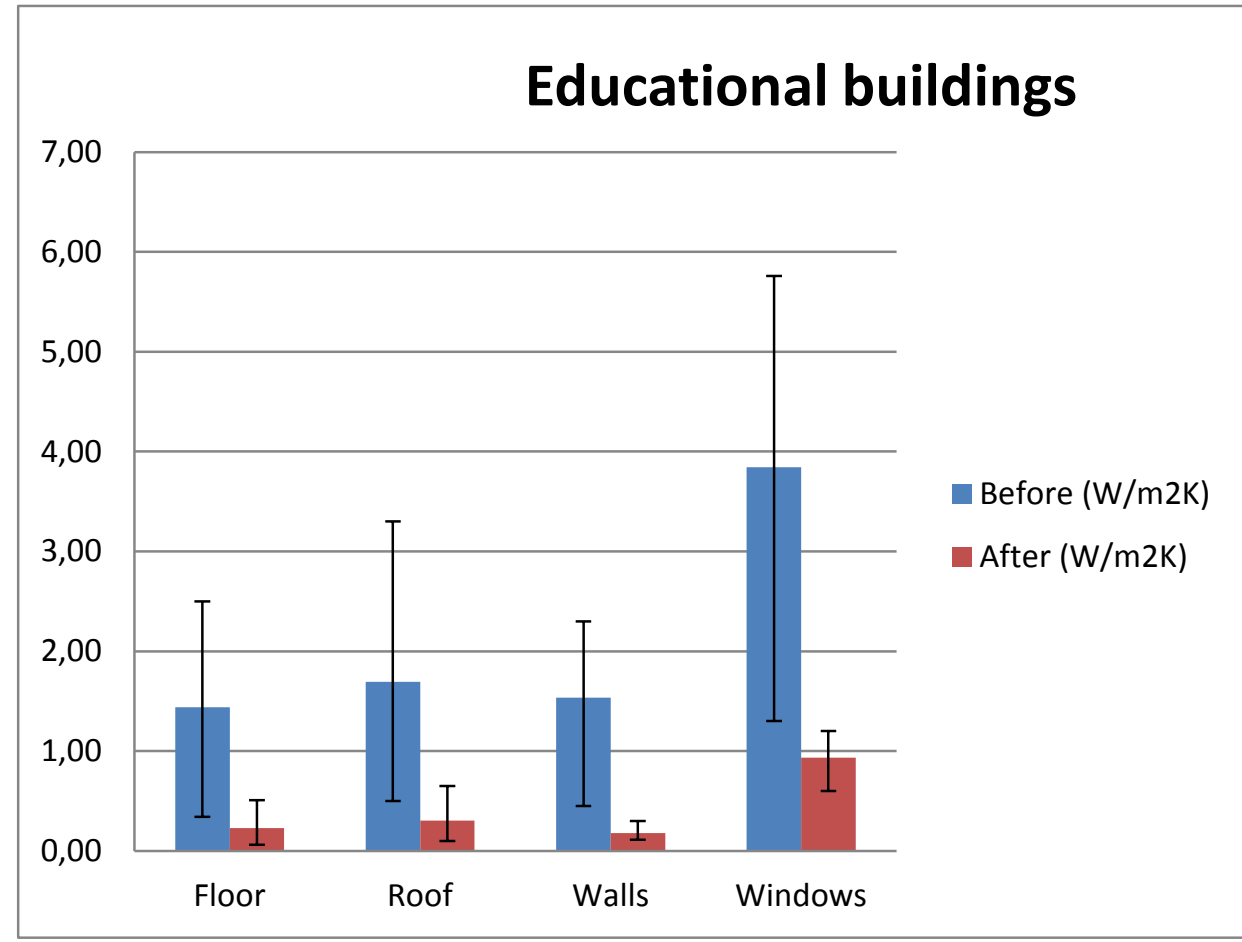

Figure 6 Average and $\min$ and $\max U$-values $(\mathrm{W} / \mathrm{m} 2 \mathrm{~K})$ for educational buildings
The figure shows that the windows have the greatest absolute change in U-value, and the walls have the greatest relative change. The walls were supplied with $120-240 \mathrm{~mm}$ of extra insulation. Two of the schools have been renovated to passive house standard according to national standards.

The kindergarten in Høje-Taastrup, the school in Cesena and the Riva Bella School have also focused on thermal bridge avoidance.

In the kindergarten Vejtoften in Høje-Taastrup, the thermal bridges in the floors/slabs were reduced significantly by insulating the foundation with $200 \mathrm{~mm}$ insulation on the outside to a depth of $400 \mathrm{~mm}$. The thermal bridges in the walls were also reduced significantly.

The building envelope was insulated with $290 \mathrm{~mm}$ insulation with a new cladding of fibre-cement. Existing traditional double glazed windows were replaced by larger triple-glazed.

On the roof, $390 \mathrm{~mm}$ insulation was added to the existing $145 \mathrm{~mm}$.

The school in Cesena had brick walls and internal plastering insulated on the outside with $120 \mathrm{~mm}$ glass wool panels, floor and roof insulated with 100 $\mathrm{mm}$ polystyrene. The old windows were replaced by new double glazed windows with PVC frames. The part of the floor covering non-heated spaces was insulated. The rest of the floor on ground was

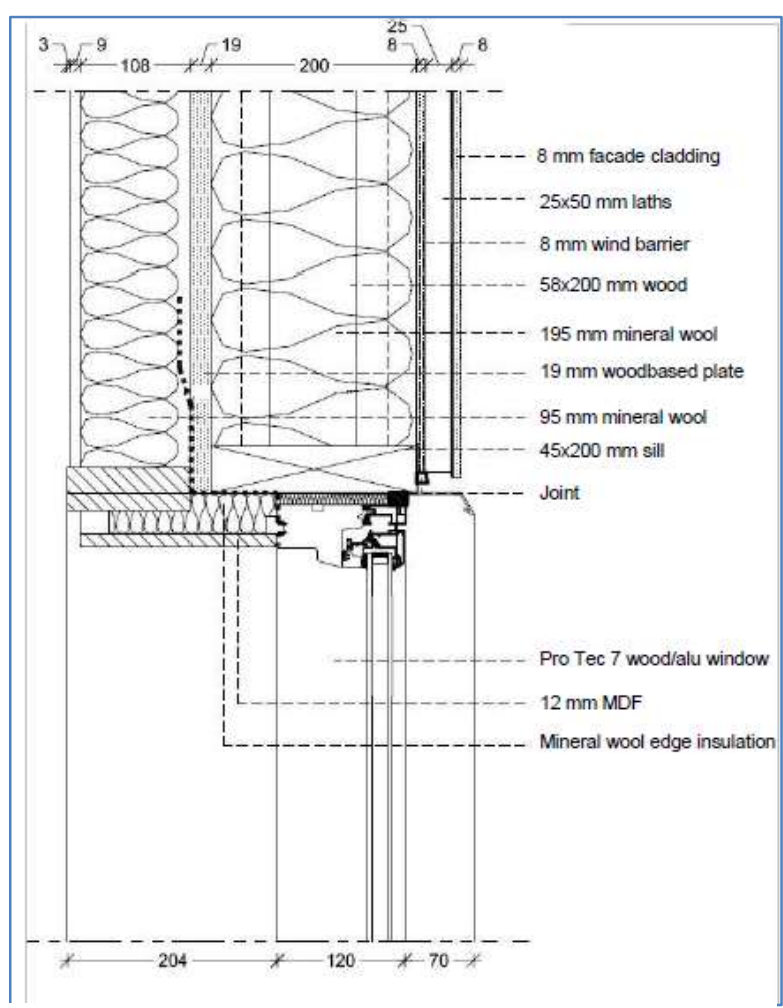

Figure 7 Kindergarten Vejtoften: Cross section of window/wall joint not insulated due to high costs. 
In the school in Schwanenstadt, the building was renovated to meet the passive house standard and prefabricated façade elements were used. The picture shows the façade elements being installed. The wall construction includes $150 \mathrm{~mm}$ concrete, reinforced concrete and solid wood construction with cellulose insulation, an extra layer
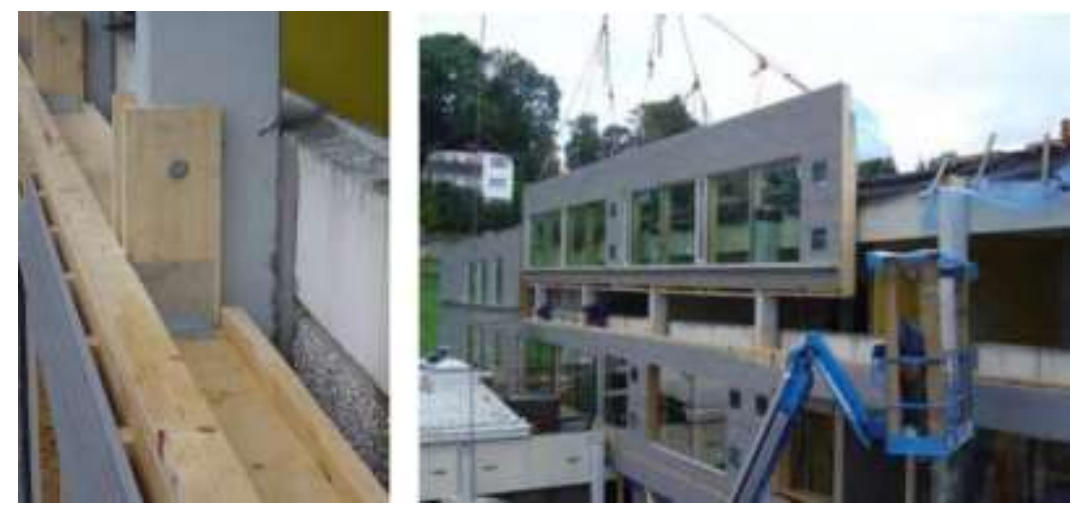

Figure 8 School in Schwanenstadt: installation of facade elements of cellulose insulation (150 mm), breathable wooden panels, battening and the wooden façade.

In the Riva Bella School the overall design strategy was a low-energy retrofitting with structural mesh conservation and reuse of different existing components and materials. Roof, walls, floors/slabs were insulated and windows were replaced. Thermal bridges were eliminated by a clear dissociation between the façade and the rest of the structure and a continuing insulation.

ASO4 is a non-frame construction that meets passive-house standard. One extra floor was added to the building despite the weak existing bearing structure. This was solved by using lightweight timber structure. More than $420 \mathrm{~mm}$ insulation (extruded polystyrene) was added to the roof.

\subsection{Technical system}

Table 1 shows the renewable and heating installations in the schools. Total installation of PV is $71.4 \mathrm{~kW}_{\mathrm{p}}$. Two of the schools have no renewable installations, and one of these schools has heating supplied by the district heating system.

Table 1 Renewable/heating installations in educational buildings

\begin{tabular}{|l|c|c|c|c|}
\hline & Solar & $\begin{array}{c}\text { Solar (PV): } \\
\mathbf{W}_{\mathbf{p}} / \mathbf{m}^{2}\end{array}$ & Other renewables & Other heat source \\
\hline Kindergarten Vejtoften (DK) & & & & District heating \\
\hline School of Cesena (IT) & $64.7 \mathrm{~kW}_{\mathrm{p}} \mathrm{PV}$ & 10.1 & & Gas condensing boilers \\
\hline School in Schwanenstadt (AT) & $6.7 \mathrm{~kW}_{\mathrm{p}} \mathrm{PV}\left(68 \mathrm{~m}^{2}\right)$ & 1.1 & $110 \mathrm{~kW}$ pellets & Gas condensing boilers \\
\hline Riva Bella School (BE) & $\begin{array}{r}\text { DHW solar system } \\
\left(23.4 \mathrm{~m}^{2}\right)\end{array}$ & & & District heating \\
\hline ASO 4 Karlhofschule Linz (AT) & & & & \\
\hline
\end{tabular}

Table 2 shows the lighting and ventilation measures implemented in the educational buildings. None of the schools has mechanical cooling, but three of them have nighttime cooling via ventilation or free cooling. All buildings except for the kindergarten implemented measures for improved lighting (enhanced use of daylight and/or energy efficient lighting). 
Most of the schools were upgraded with a mechanical ventilation system with an efficient heat recovery system.

Table 2 Technical building installations in educational buildings

\begin{tabular}{|l|l|l|l|}
\hline & \multicolumn{1}{|c|}{ Lighting } & \multicolumn{1}{|c|}{ Cooling } & \multicolumn{1}{|c|}{ Ventilation system } \\
\hline Kindergarten Vejtoften (DK) & Installed earlier. & No cooling. & $\begin{array}{l}\text { New vent system with increased } \\
\text { efficiency, heat recovery (72\%). }\end{array}$ \\
\hline School of Cesena (IT) & Daylight controlled. & $\begin{array}{l}\text { No cooling, external shading to } \\
\text { avoid overheating. }\end{array}$ & $\begin{array}{l}\text { Mechanical ventilation with heat } \\
\text { recovery. }\end{array}$ \\
\hline School in Schwanenstadt (AT) & $\begin{array}{l}\text { Enhanced use of } \\
\text { daylight. }\end{array}$ & $\begin{array}{l}\text { Nighttime ventilation and solar } \\
\text { shading. }\end{array}$ & Decentralized. \\
\hline Riva Bella School (BE) & Daylight controlled & Free and night cooling. & Heat recovery 85 \%. \\
\hline ASO 4 Karlhofschule (AT) & $\begin{array}{l}\text { Daylight concept in } \\
\text { shading elements. }\end{array}$ & $\begin{array}{l}\text { Nighttime ventilation in } \\
\text { summer }\end{array}$ & $\begin{array}{l}\text { Classrooms with demand controlled } \\
\text { ventilation system }\end{array}$ \\
\hline
\end{tabular}

The Kindergarten Vejtoften replaced the old ventilation system with a more energy efficient system and achieved a $31 \%$ decrease in demand for electricity. There is no cooling installed, and there were no changes to the heating system, which is connected to the district heating.

In the school in Cesena, two natural gas boilers ( $2 \times 285 \mathrm{~kW})$ were replaced by condensing and modulating boilers. There is no cooling system installed. The previous working temperature for the heating system was reduced and thermostatic valves were installed on radiators to improve IAQ. The existing natural ventilation system was replaced partly with demand-controlled ventilation and a more efficient control system for the natural ventilation. A new daylight controlled lighting system was installed. $100 \%$ of the electricity demand is now covered by a $65 \mathrm{~kW}$ PV system.

The school in Schwanenstadt has a decentralized ventilation system with heat recovery. There is no mechanical cooling installed, but passive cooling is used through the nighttime ventilation. The school installed a $110 \mathrm{~kW}$ pellets boiler and a $6.7 \mathrm{~kW}$ PV system $\left(68 \mathrm{~m}^{2}\right)$. The renovation also enhanced the use of daylight.

The Riva Bella School increased glazing in the façade to improve the daylight availability; solar shading was installed in the east and west façade, and daylight sensors were installed in every classroom. The old fuel-based heating was replaced by two condensing gas boilers. There is no mechanical cooling installed, but the free- and night cooling. A thermal solar system for cooking and hairdressing classrooms was planned for, but implementation of this installation was postponed due to financial reasons.

The ASO4 Karlhofschule has been renovated to passive house standard, classrooms were equipped with ventilation; the airflow can now be adjusted. A sophisticated setup for nighttime ventilation during the summer was installed. The building now includes a $23.4 \mathrm{~m}^{2}$ solar thermal system for domestic hot water supply. 


\subsection{Energy}

Table 3 below shows the reduction in reported energy use for the different educational buildings. It is not possible to compare the energy result for the different schools and kindergartens due to a variety in reported energy numbers and calculation methods.

All of the schools show a significant reduction in energy consumption. There are no available numbers for the ASO4 from before the renovation.

Table 3 Energy use education buildings [kWh/m2]

\begin{tabular}{|l|c|c|c|l|}
\hline & \multicolumn{2}{|c|}{$\begin{array}{c}\text { Specific annual energy } \\
\mathbf{k W h} / \mathbf{m}^{2}\end{array}$} & & \\
\hline Building & Before & After & Reduction & Description \\
\hline Kindergarten Vejtoften (DK) & 158 & 87 & $45 \%$ & Heat, DHW and electricity. Calculated consumption. \\
\hline School of Cesena (IT) & 154 & 32 & $79 \%$ & $\begin{array}{l}\text { Global EP - index (not incl. IT and lighting). 100\% } \\
\text { electricity by PV is included. Calculated. }\end{array}$ \\
\hline School in Schwanenstadt (AT) & 143 & 34 & $77 \%$ & $\begin{array}{l}\text { Delivered energy. Calculated. } \\
\text { Primary energy demand 59,3 kWh/m2/y }\end{array}$ \\
\hline Riva Bella School (BE) & 180 & 35 & $81 \%$ & Heating demand. Calculated. \\
\hline ASO 4 Karlhofschule Linz (AU) & n.a & 3 & - & $\begin{array}{l}\text { Heating demand (energy certificate), primary energy } \\
\text { demand 148 kWh/m² }\end{array}$ \\
\hline
\end{tabular}

In the kindergarten Vejtoften, measurements of the consumption for heating and hot water were carried out before and after the renovation. The measurements show that the heat consumption has dropped by $54 \%$. Calculations show an expected reduction of the total energy demand by $45 \%$.

The school in Cesena covers up to $100 \%$ of their electric energy demand (of all electricity devices, lighting, computers, etc.) with the PV system. The heating demand is reduced from $137 \mathrm{kWh} / \mathrm{m}^{2}$ to 32 $\mathrm{kWh} / \mathrm{m}^{2}(77 \%)$ according to the EP index.

The school in Schwanenstadt has now an annual heating demand of $14.1 \mathrm{kWh} / \mathrm{m}^{2}$, which is a reduction of $85.5 \%$ compared to the old building. The end energy demand is reduced by $76.5 \%$ to $33.6 \mathrm{kWh} / \mathrm{m}^{2}$.

The Riva Bella School has been unoccupied for the last 15 years. It is therefore difficult to obtain data about its energy performance before the renovation. However, it is estimated to be $180 \mathrm{kWh} / \mathrm{m}^{2}$. The heat demand after renovation is calculated to be $35 \mathrm{kWh} / \mathrm{m}^{2}$.

ASO4 Karlhofschule has no available numbers from before the renovation. 


\subsection{Economy}

Table 4 shows the extra cost for renovating to a higher energy standard. The extra cost lies between 64 and $142 € / \mathrm{m}^{2}$, and is on average $104 € / \mathrm{m}^{2}$.

Table 4 Renovation costs for the educational buildings

\begin{tabular}{|c|c|c|c|}
\hline & $€ / \mathrm{m}^{2}$ & Comment & Public funding \\
\hline Kindergarten Vejtoften (DK) & 64 & $\begin{array}{l}\text { Extra cost of renovating the building envelope to low } \\
\text { energy standard. Total cost } 575 € / \mathrm{m}^{2} \text {. }\end{array}$ & \\
\hline School of Cesena (IT) & 120 & & $\begin{array}{l}\text { FP7 contribution and funding } \\
\text { from municipality. }\end{array}$ \\
\hline School in Schwanenstadt (AT) & 142 & $\begin{array}{l}\text { Additional costs to } \mathrm{PH} \text {-standards ( } 9.1 \% \text { add.costs) and } \\
\text { other energy related equipment ( } 2.4 \% \text { add.costs) . } \\
\text { Including renovation + expansion. }\end{array}$ & $\begin{array}{l}\text { Funding for energy-related } \\
\text { costs. }\end{array}$ \\
\hline Riva Bella School (BE) & 89 & Extra investment for energy savings & $\begin{array}{l}\text { Funded by French Speaking } \\
\text { Community (SPABS). The costs } \\
\text { include subsidies. }\end{array}$ \\
\hline ASO 4 Karlhofschule Linz (AT) & n.a. & & \\
\hline
\end{tabular}

For the kindergarten Vejtoften, the total cost of renovation was $€ 200,000$ or $575 € / \mathrm{m}^{2}$ and was financed by the municipality without any external funding. The extra cost of renovating the building envelope to a higher energy standard was approximately $22,250 €$ or $64 € / \mathrm{m}^{2}$ to invest in better windows (3-layers of glass) and better insulation. Extra investment in low energy is profitable, because the energy savings throughout the building envelope life (set to 40 years) become even greater. The total net savings will be approximately $€ 32,000$ for a typical institution.

School of Cesena and the Riva Bella School were the only projects that received subsidies. The renovation of school of Cesena was funded with European funds. The rest of the project was funded through the Municipal funding program for energy refurbishment of the school building stock. The renovation of the Riva Bella School was also subsidized. The school in Schwanenstadt has the highest investment cost, this may be because these costs are related to passive house standard and include other energy-related equipment not only for the renovation, but also the expansion (new built).

The School in Cesena- project was funded partly from the Municipal funding program for energy refurbishment of the school building stock. European funds were also used (7th FWP, about $603 \mathrm{k} €$, funded at $75 \%)$. The renovation costs are low $\left(120 € / \mathrm{m}^{2}\right)$ due to the effective initial planning.

The cost for renovation and expansion in the school in Schwanenstadt was 7,700,000 € including $700,000 €$ for $\mathrm{PH}$-technology and $185,000 €$ for other energy related equipment.

The renovation of the Riva Bella school had an extremly low budget, and the total cost of the renovation was $3,800,000 €$, or $845 € / \mathrm{m}^{2}$, including subsidies. The extra investment for the energy saving measures was around $400,000 €$. Expected payback time is approximately 15 years.

There are no available costs for ASO4 Karlhofschule. 


\subsection{Environment}

All of the educational buildings have experienced a better indoor climate and an increased quality of life. Two of the schools have been environmentally classified.

Table 5 Environmental indicators in educational buildings

\begin{tabular}{|c|c|c|c|c|c|c|}
\hline & $\begin{array}{l}\text { Improved } \\
\text { lighting } \\
\text { quality }\end{array}$ & $\begin{array}{c}\text { Improved } \\
\text { indoor thermal } \\
\text { climate }\end{array}$ & $\begin{array}{l}\text { Improved } \\
\text { air quality }\end{array}$ & $\begin{array}{c}\text { Better } \\
\text { acoustics }\end{array}$ & $\begin{array}{c}\text { Enviroment. } \\
\text { classified }\end{array}$ & Materials \\
\hline Kindergarden Vejtoften (DK) & & $x$ & $x$ & & & $\begin{array}{l}\text { New facade requires } \\
\text { little maintenance }\end{array}$ \\
\hline School of Cesena (IT) & $\mathrm{X}$ & $\mathrm{x}$ & $x$ & $x$ & & Ecological materials \\
\hline School in Schwanenstadt (AT) & $x$ & $\mathrm{x}$ & $\mathrm{x}$ & & $\begin{array}{l}\text { Total Quality } \\
\text { Building } \\
\text { Certif. (TQB) }\end{array}$ & Ecological materials \\
\hline Riva Bella School (BE) & $x$ & $x$ & & & & Reuse of materials \\
\hline ASO 4 Karlhofschule (AT) & $x$ & $x$ & $x$ & & Klima:aktiv & Ecological materials \\
\hline
\end{tabular}

The kindergarten Vejtoften experiences a better indoor climate after the renovation. The measures for the building envelope reduced the draught and generally improved the thermal comfort. The indoor air quality improved due to the new ventilation system.

The School in Cesena have not done any analysis or had particular attention to the environmental issues, but there is registered a better indoor climate, increased quality of life and better indoor air quality.

The school in Schwanenstadt is certified by the Total Quality Building Certificate (TQB). This includes resource conservation, harmful impacts on humans and the environment, user comfort, durability, safety and security, planning quality, infrastructure and equipment and overall assessment. The results are shown in the figure below. The best possible TQB-value is five.

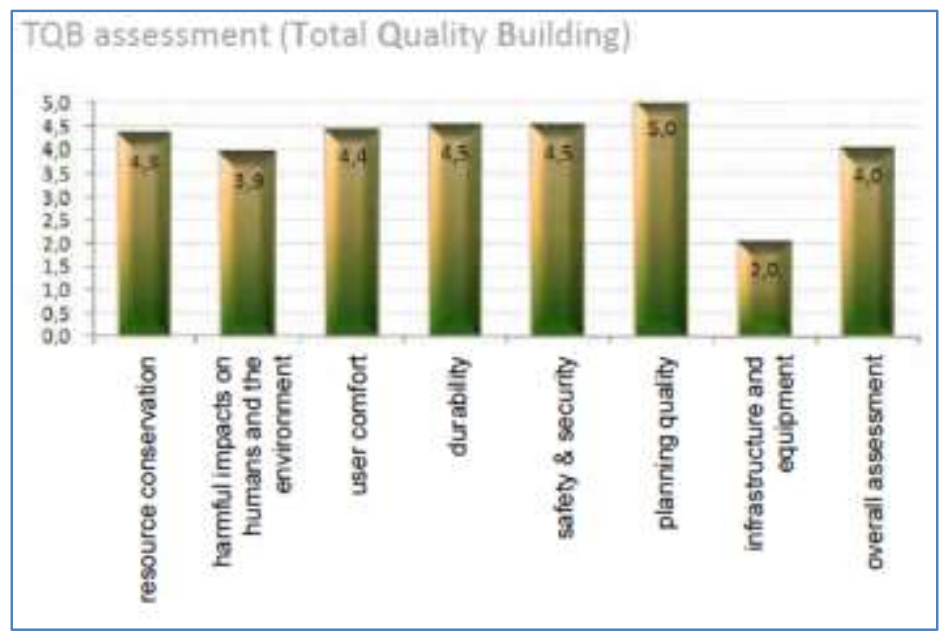

Figure 9 Total Quality Building Certificate for Schwanenstadt 
Other environmental results for the school in Schwanenstadt are: use of ecological materials, increased quality of life, use of renewable energy sources, fast renovation and use of prefabricated components, improved lighting quality and enhanced use of daylight.

The Riva Bella School has also experienced an increased quality of life. Water management is implemented including a $200 \mathrm{~m}^{3}$ tank for rainwater. In the renovation phase, the focus was on the reuse of existing components and materials.

The ASO4 Karlhofschule has experienced after the renovation a better indoor climate with regards to lighting, thermal climate and air quality.

\subsection{Decision process}

The main incentives for the renovation of the kindergarten Vejtoften was to reduce energy consumption and improve indoor climate. The kindergarten is owned by the municipality of Høje-Taastrup which also owns 26 other kindergartens. It was decided that instead of making minor energy renovations in all 27 institutions, it was more cost-efficient to make more energy ambitious renovations in a few buildings at the time.

The idea of renovating the School in Cesena was born in the beginning of 2011, detailed project description was completed in December 2011, the contractor was signed in spring 2012, the renovation started in summer 2012 and was completed in the beginning of 2014, reaching (and surpassing) energy saving expectations.

A conventional renovation project for the school in Schwanenstadt was due and plans for it were ready. A call for sustainable renovation demonstration projects within the Austrian Research Program was launched and a study to reach PH-standards for the school was funded as a research project. After the study, the demonstration project was submitted. Prejudices against mechanical ventilations were solved by excursions to other Austrians schools as well as a one-year testing in a prototype classroom at the school. The renovation was completed in October 2007, and a monitoring program ended in May 2009.

The Riva Bella School was built in 1970. It has not been in use since 1995 for reasons relating to firesafety and presence of asbestos. In 2008, the Ministry of the French Community and the Société publique d'administration des bâtiments scolaires (SPABS) decided to renovate the building while maintaining the existing structure. The competition was organized in 2008, the contract was signed in 2010 and the renovation was completed in 2012. 


\section{Office buildings}

\subsection{Short introduction of the buildings}

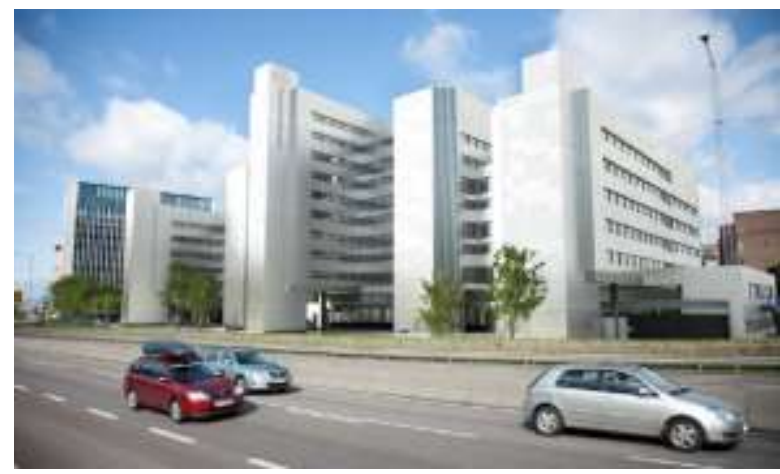

\section{Norwegian Tax Authority Oslo (NO)}

The building from 1982 is situated in the center of Oslo, and had no previous renovations. The entire building had an area of $29000 \mathrm{~m}^{2}$ (internal area without outer walls) and it was designed for approximately 1300 persons. Approximately $6000 \mathrm{~m}^{2}$ of area was added during the renovation. The overall goal is energy label $\mathrm{A}$ and $\mathrm{PH}$-level (no Norwegian $\mathrm{PH}$ standards at that time). Energy label A was achieved, and the building was built according to the passive house level.

\section{Powerhouse Kjørbo (NO)}

The renovation includes two blocks located about $15 \mathrm{~km}$ west of Oslo, no past renovations. The buildings have a total area of $5180 \mathrm{~m}^{2}$ (internal area without outer walls), and it is designed for approximately 240 persons. The idea was born in 2011 and the renovation was completed by March 2014. The buildings are renovated to plus-energy standard.
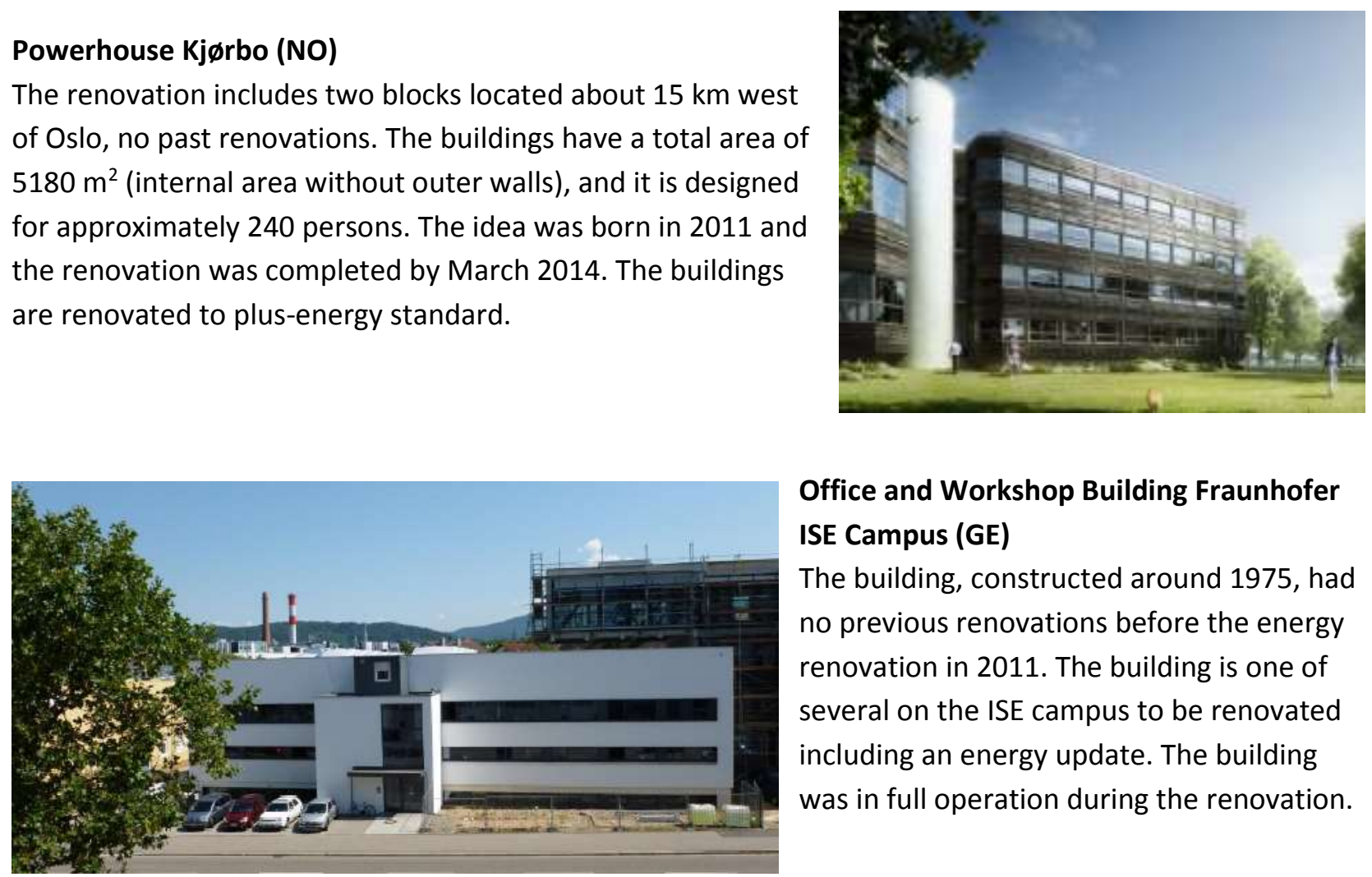

Office and Workshop Building Fraunhofer ISE Campus (GE)

The building, constructed around 1975, had no previous renovations before the energy renovation in 2011. The building is one of several on the ISE campus to be renovated including an energy update. The building was in full operation during the renovation.

\section{Printing Workshop and Office building (DE)}

The building was constructed around 1978. The renovation phase was implemented in two steps, with phase one in 2005 and phase two in 2011. The objective of the renovation was to reduce the high energy demand. The building area was enlarged with a $2^{\text {nd }}$ floor of $1100 \mathrm{~m}^{2}$.

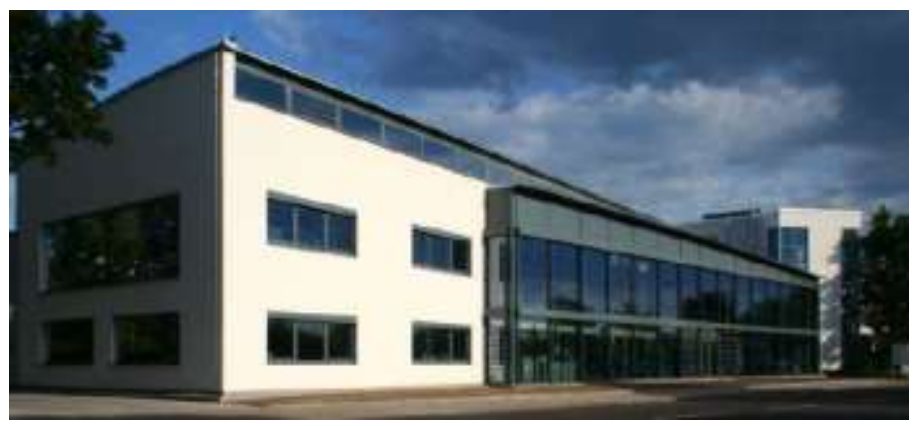




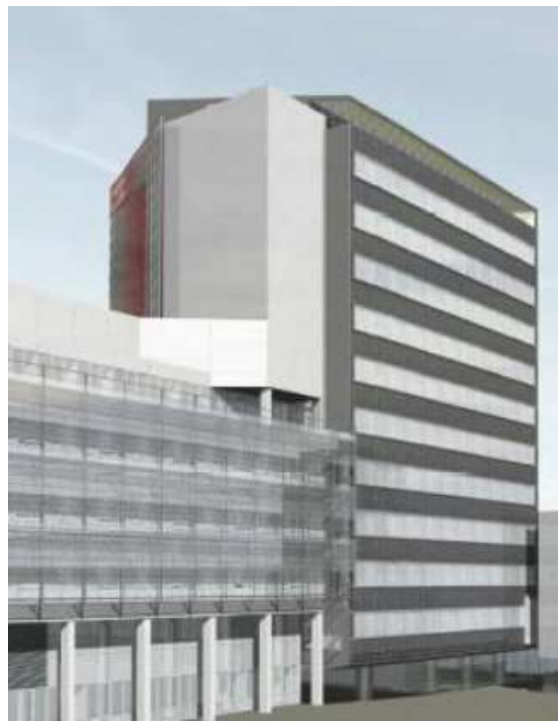

\section{Office Building, Roskilde (DK)}

The building was built in 1968, and was a typical precast concrete building with limited level of insulation. In 1991, the building envelope was renovated and insulation was added to the wall $(175 \mathrm{~mm})$ and the windows were replaced with double-glazed windows. The main objective of the 2010 renovation was to improve the energy performance of the building, while also improving the indoor climate. A new penthouse was added to the top of the building.

\section{TU Vienna Plus Energy (AT)}

The building is from the 1970s, and the project was part of larger renovation activities of the TU Vienna. After renovation, the building has become the largest plus- energy building in Austria, with the biggest façade-integrated photovoltaic system.

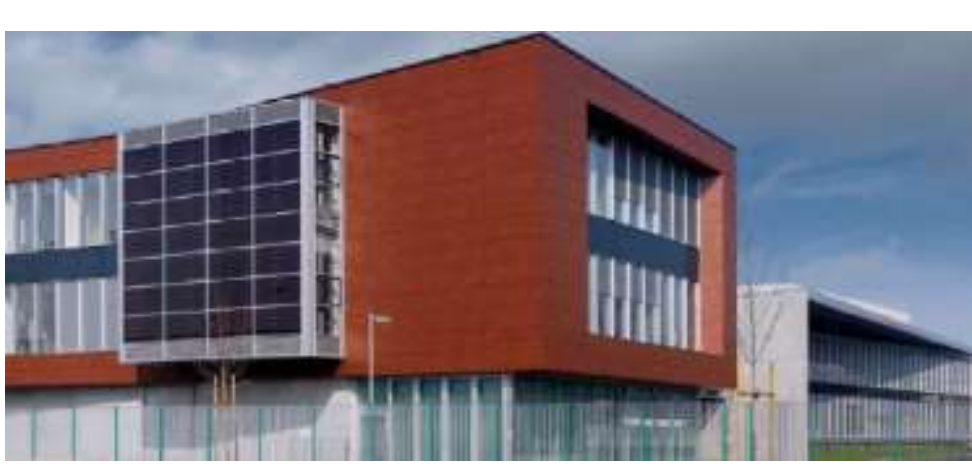

\section{Schüco Italian Headquarters (IT)}

Schüco is a developer of windows, doors, façades and solar solutions. The objective of the project was to increase the office area, create a showroom and a restaurant area. The original building was constructed in 1990, and there were no past renovations. In addition to refurbishment of the original building, there was built an adjacent new building. The existing building has a gross conditioned area of $1515 \mathrm{~m}^{2}$ and the new building has a gross conditioned area of $2796 \mathrm{~m}^{2}$. 


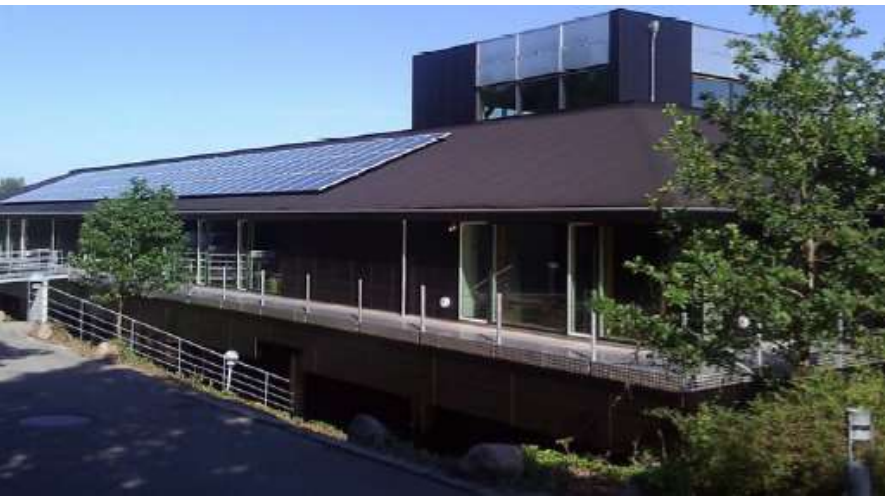

\section{Rockwool International Office Building} "Center 2" (DK)

The construction year of the building is 1979 . The aim of the renovation was to upgrade the energy performance to meet the future Danish low energy class 2015 for new buildings and to achieve a high quality office workspace.

\section{Solbråveien office center, Asker (NO)}

The building was constructed in 1980 and 1982 .

There were no past energy renovations.

Before the renovation, the office building had low letting rates, high energy use, outdated technical systems and an ineffective area for the tenants. Therefore, there was a need for a general renovation. The objective of the renovation was to achieve Energy Label B and the Norwegian Low energy building class.
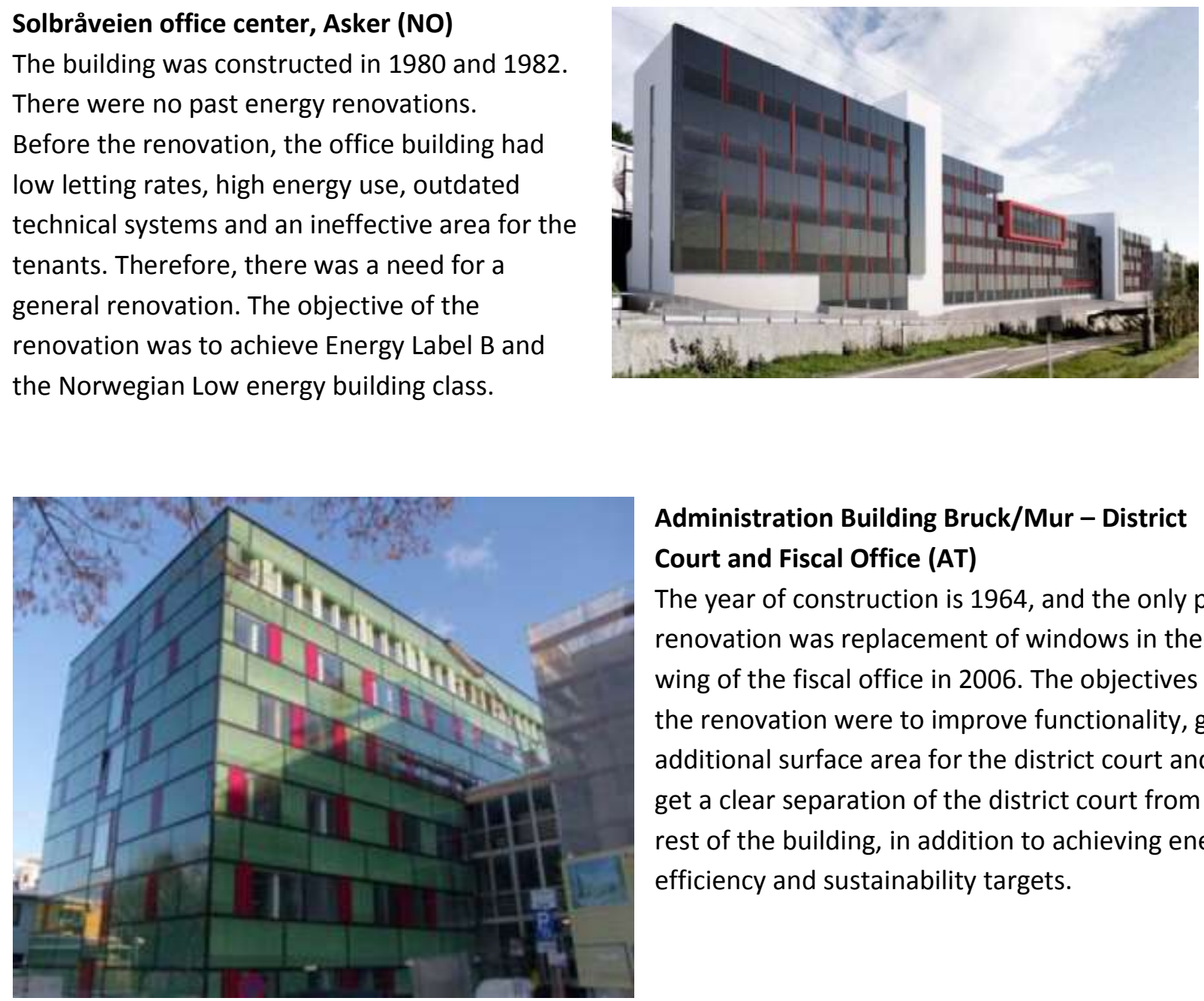

\section{Administration Building Bruck/Mur - District} Court and Fiscal Office (AT)

The year of construction is 1964, and the only past renovation was replacement of windows in the wing of the fiscal office in 2006. The objectives of the renovation were to improve functionality, get additional surface area for the district court and get a clear separation of the district court from the rest of the building, in addition to achieving energy efficiency and sustainability targets. 


\subsection{Envelope}

All off the office buildings implemented changes to the building envelope. Five of the office buildings enlarged the building area.

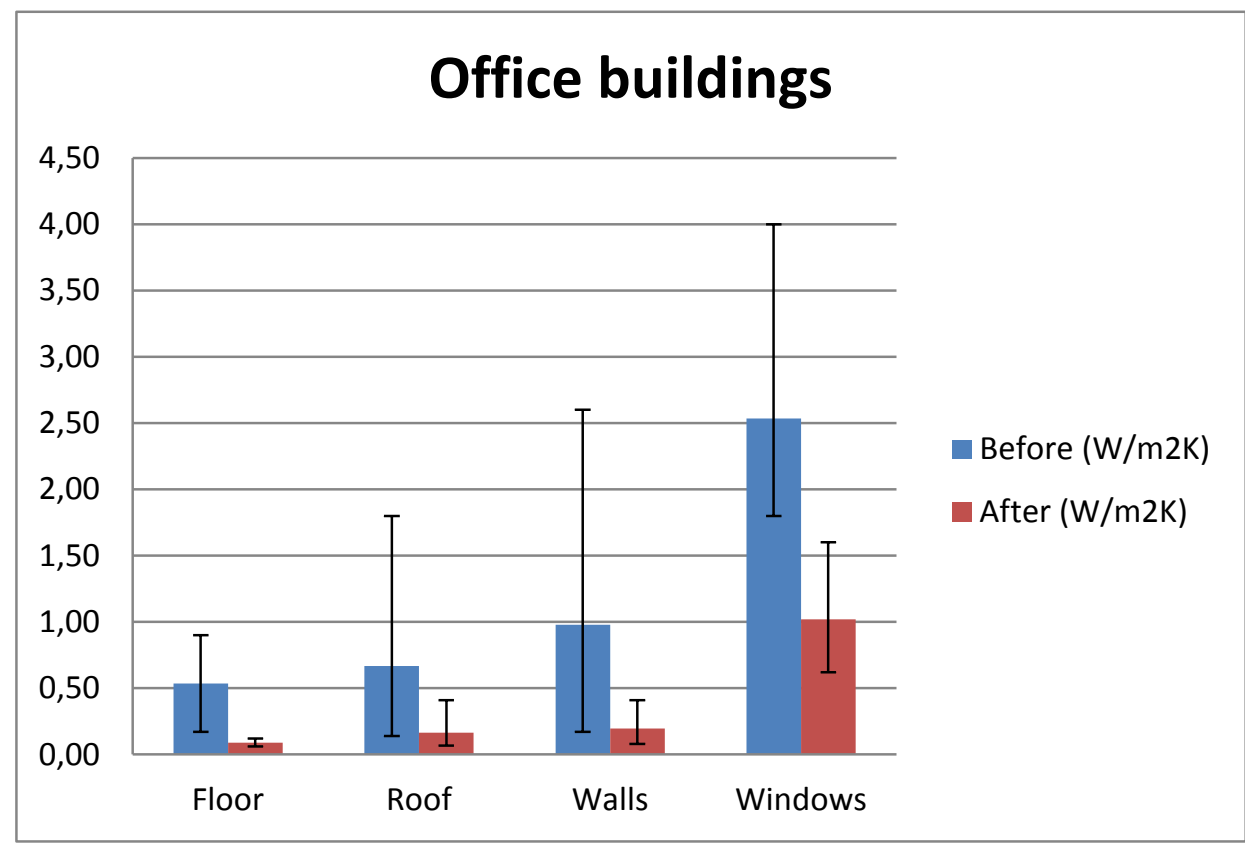

Figure 10 Average and $\min$ and $\max U$-values $(\mathrm{W} / \mathrm{m} 2 \mathrm{~K})$ for office buildings
None of the office buildings had insulation added to the ground slab. The Rockwool building and the TU Vienna Plus house implemented measures for the part of the floor which was exposed to air and the figure 10 includes these values. The Rockwool building improved the $U$-value in the part of the floor that is adjacent to the parking deck, from 0.17 to $0.06 \mathrm{~W} / \mathrm{m}^{2} \mathrm{~K}$ (between 300 and $750 \mathrm{~mm}$ mineral

wool). The TU Vienna plus energy building carried out measures for the floor exposed to air. The U-values was improved from 0.9 to $0.12 \mathrm{~W} / \mathrm{m}^{2} \mathrm{~K}$. Several buildings also implemented measures for the basement walls, but these are included in the U-values for walls. Of all the building components, the windows have the absolute greatest improvement.

The Norwegian Tax Authority, the Powerhouse Kjørbo and the Office Building in Roskilde had a focus on reducing thermal bridges. In the Powerhouse Kjørbo, this was done by focusing on the thermal bridge avoidance in the windows and with the $200 \mathrm{~mm}$ insulation in front of the slabs where concrete slabs meet the wooden façade.

The Norwegian Tax Authority, the Powerhouse Kjørbo and The U Vienna Plus Energy building have reported an improvement in the air tightness of the building. In the building of the Norwegian Tax Authority the air leakage was calculated to be $0.6 \mathrm{~h}^{-1}$ and in the Powerhouse Kjørbo it was calculated to be $0.6 \mathrm{~h}^{-1}$, but later measured to be $0.2 \mathrm{~h}^{-1}$.

The Norwegian Tax Authority used pre-fabricated facades. The focus was on eliminating thermal bridges in the windows. $200 \mathrm{~mm}$ insulation was added in front of the slabs. A design principle was used where the envelope area-to-volume ratio was reduced to avoid "cooling fingers".

The Powerhouse Kjørbo was totally stripped except for the main concrete construction structure. The outer walls were all rebuilt and insulated with $300 \mathrm{~mm}$ insulation. New triple-glazed windows were installed. 
The overall objective of the renovation of the Office and Workshop Building Fraunhofer ISE Campus was to achieve an overall renovation of the building envelope, because the roof was leaking, the windows were worn out, and the overall thermal comfort situation was not satisfying. The renovation was done during full operation of the building, and the windows were replaced in one day. Mainly prefabricated elements were used in the renovation. Complete new roofing, with $140 \mathrm{~mm}$ sandwich panel insulation, was added on top of the existent sheds, large skylights were replaced by smaller double-glazed skylights. The existing wall construction had $30 \mathrm{~mm}$ insulation in a concrete prefabricated sandwich panel. $220 \mathrm{~mm}$ of insulation with a cladding was added. The original base/foundation had no insulation and therefore $160 \mathrm{~mm}$ of insulation was added on the outside to a depth of $400 \mathrm{~mm}$. Existing traditional double-glazed windows were replaced by new double-glazed windows.

In the Schüco Italia Headquarters there were implemented measures for the roof, walls and windows. To the roof there was added $20 \mathrm{~mm}$ of plasterboard, $70 \mathrm{~mm}$ air space, $400 \mathrm{~mm}$ concrete slab, $120 \mathrm{~mm}$ polystyrene insulation, waterproofing and $300 \mathrm{~mm}$ gravel tiles. The walls were insulated with Rockwool and polystyrene $(140 \mathrm{~mm})$. In addition to refurbishment of the original building, there was built an adjacent new building.

The Office Building in Roskilde was built in 1968, and is a typical precast concrete building with limited amount of insulation. In 1991, the building envelope was renovated and insulation was added to the wall. During the 2010 renovation, a new penthouse was built on the top of the building. The existing roof (terrace) had $190 \mathrm{~mm}$ insulation and the new roof has $300-450 \mathrm{~mm}$ insulation. In the walls, $150 \mathrm{~mm}$ insulation was added to the existing $250 \mathrm{~mm}$, and fiber-cement cladding was added. The foundation had no insulation and therefore the $150 \mathrm{~mm}$ 's added to the wall was extended to cover the base of the building. The basement walls below ground are not insulated. Traditional double-glazed windows were replaced by triple-glazed windows.

The Printing Workshop and Office building was enlarged by a 2 nd floor. The new building envelope is a lightweight steel construction, with an intermediate concrete ceiling exposed and ceiling panels with phase change materials (PCM) to enforce the thermal storage effect. The roof was insulated with $180 \mathrm{~mm}$ mineral fiber, and the walls were insulated with 120 mm EIFS.
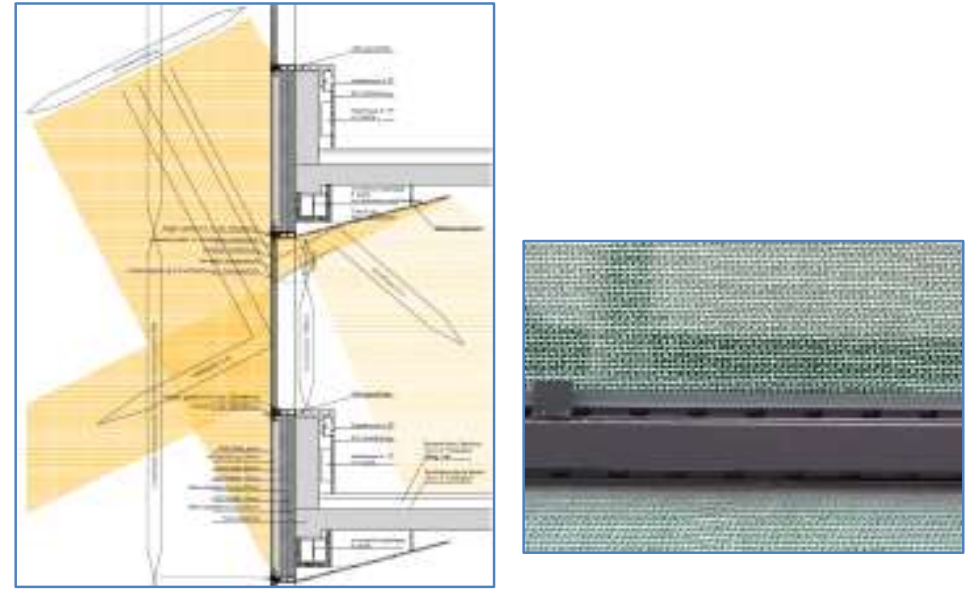

Figure 11 Cross section of wall and window and solar comb for the administration Building Bruck/Mur

\section{The administration Building Bruck/Mur} used prefabricated metal cladding panels with solar combs for passive solar exploitation.

The wall construction from interior to exterior is shown in picture 9 . From the inner to the outer layer the wall includes a chalk-cement plastering, concrete brick, chalk-cement plastering, rock wool insulation $(200 \mathrm{~mm})$ and a solar comb façade consisting of air space $(4 \mathrm{~mm})$ and glass $(5 \mathrm{~mm})$. The solar comb façade is shown in Figure 11. 
The Solbråveien office centre implemented measures for the façade and the roof. The external façade was insulated with $120 \mathrm{~mm}$ mineral wool, wind barrier, air space and glass facade. Windows of the passive house standard were installed. There was added interior insulation of $100 \mathrm{~mm}$ mineral wool, vapor barrier and $13 \mathrm{~mm}$ plasterboard. There was also laid insulation $(200 \mathrm{~mm})$ in cavity under the wooden roof. No measures were done to the floor.

\section{The Rockwool International Office Building}

installed new facades with three-layer windows. Extra $180 \mathrm{~mm}$ high-density mineral wool insulation and granulate was installed in the parking deck. The wall construction consists of a gypsum board, a gypsum fiberboard, $170 \mathrm{~mm}$ mineral wool, plywood, $300 \mathrm{~mm}$ mineral wool, stone wall panels.

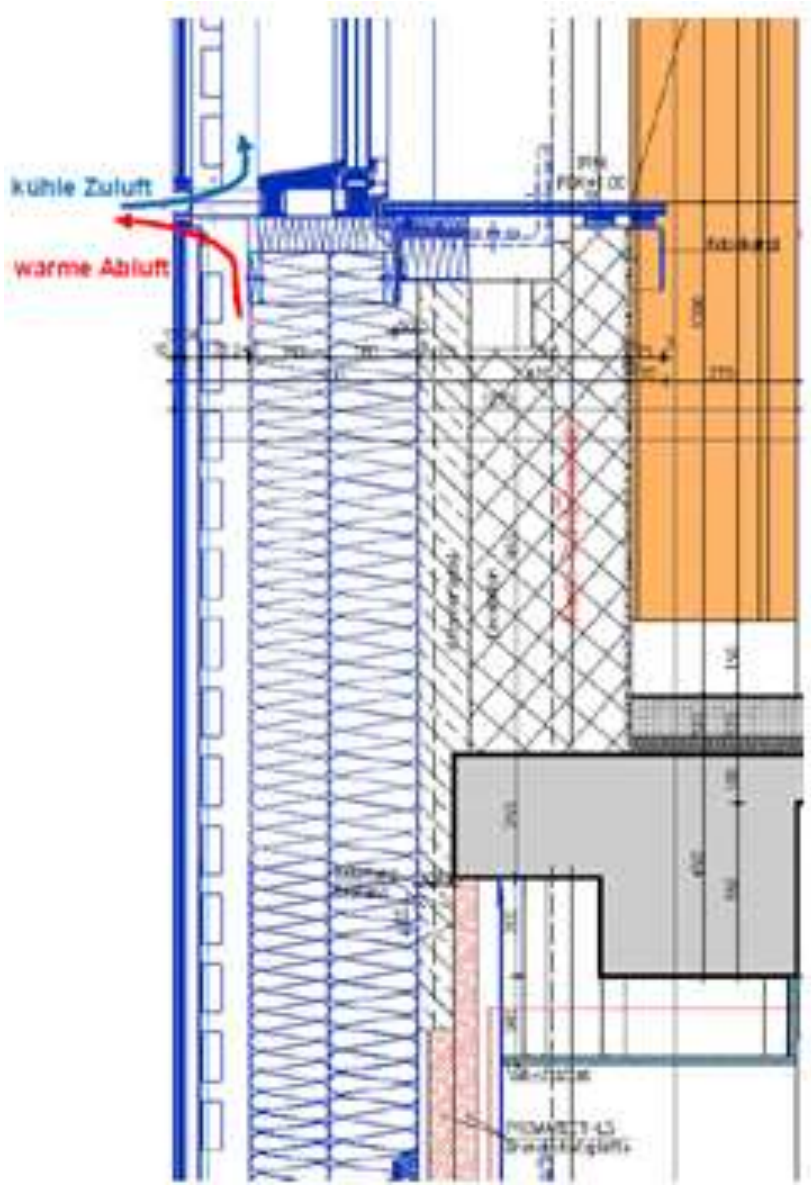

Figure 13 Example of a wall with PV panel, TU Vlenna Plus Energy building

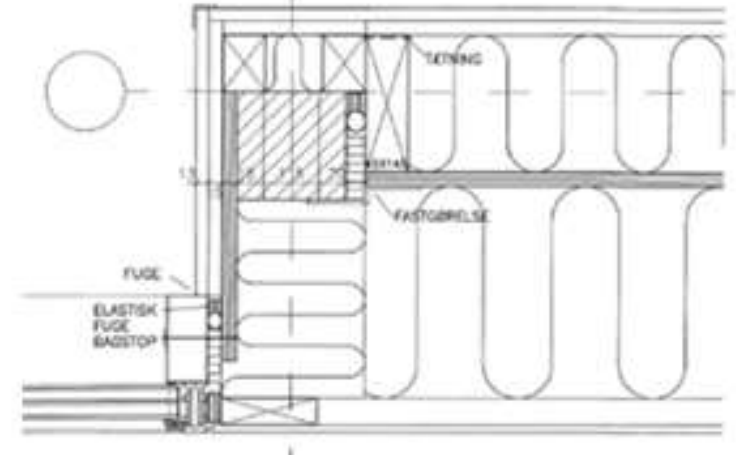

Figure $12 \mathrm{New}$ facade, u-value $0,08 \mathrm{~W} / \mathrm{m} 2 \mathrm{~K}$, Rockwool

The TU Vienna Plus Energy building implemented measures for the roof, the walls, windows and the floor that is exposed to air. An example of a wall with $\mathrm{PV}$ panels is shown in the picture. The wall consists of a render $(10 \mathrm{~mm})$, light-weight concrete $(325 \mathrm{~mm})$, a concrete compound $(105 \mathrm{~mm})$, an air proof barrier ( $2 \mathrm{~mm})$, a facade insulation wall panel $(180 \mathrm{~mm})$, a facade insulation wall panel $(160 \mathrm{~mm})$, a wind proof barrier $(130 \mathrm{~mm})$ and glazing including a PV- module (13 mm). 


\subsection{Technical system}

Table 6 shows renewable and heating installations in the office buildings. Five of the ten office buildings installed PV. Four of the office buildings installed a ground heat pump, and one building uses an air-towater heat pump. The five remaining buildings use district heating.

Table 6 Renewable/heating installations in office buildings

\begin{tabular}{|c|c|c|c|c|}
\hline Building & Solar & $\begin{array}{l}\text { Solar PV } \\
\mathrm{W}_{\mathrm{p}} / \mathrm{m}^{2}\end{array}$ & $\begin{array}{c}\text { Other } \\
\text { renewables }\end{array}$ & Other \\
\hline Tax Directorate Office Building (NO) & & & & District Heating \\
\hline Powerhouse Kjørbo (NO) & $312 \mathrm{~kW}_{\mathrm{p}} \mathrm{PV}$ & 60,2 & $\begin{array}{l}\text { Heat Pump } \\
\text { (ground) }\end{array}$ & \\
\hline $\begin{array}{l}\text { Office and Workshop Building } \\
\text { Fraunhofer ISE Campus (DE) }\end{array}$ & & & & District Heating \\
\hline $\begin{array}{l}\text { Printing workshop and office } \\
\text { building (DE) }\end{array}$ & & & $\begin{array}{c}\text { Heat Pump } \\
\text { (ground coupled) }\end{array}$ & PCM \\
\hline TU Vienna Plus Energy (DE) & $336 \mathrm{~kW}_{\mathrm{p}} \mathrm{PV}\left(2246 \mathrm{~m}^{2}\right)$ & 43,807 & & $\begin{array}{c}\text { District Heating + } \\
\text { electric boilers }\end{array}$ \\
\hline Office Building Roskilde (DK) & $5,1 \mathrm{~kW}_{\mathrm{p}}$ PV $\left(130 \mathrm{~m}^{2}\right)$ & 2,0581 & & District Heating \\
\hline Schüco Headquarter (IT) & $\begin{array}{c}600 \mathrm{~kW}_{\mathrm{p}} \mathrm{PV}+15 \mathrm{kWf} \text { cooling, } 10 \mathrm{~m}^{2} \\
\text { solar collectors for } \mathrm{DHW}\end{array}$ & 139,18 & $\begin{array}{c}\text { Heat Pump } \\
\text { (ground coupled) }\end{array}$ & Condensing boiler \\
\hline Rockwool office building (DK) & $\begin{array}{c}24 \mathrm{~kW}_{\mathrm{p}} \mathrm{PV}\left(170 \mathrm{~m}^{2}\right)+86 \mathrm{~m}^{2} \text { solar } \\
\text { collector }\left(3 \mathrm{kWh} / \mathrm{m}^{2}\right)\end{array}$ & 6,6189 & $\begin{array}{c}\text { Heat Pump } \\
\text { (ground coupled) }\end{array}$ & \\
\hline Solbråveien office centre (NO) & & & $\begin{array}{l}\text { Heat Pump } \\
\text { (Air/water) }\end{array}$ & \\
\hline $\begin{array}{l}\text { Administration Building Bruck/Mur - } \\
\text { (AT) }\end{array}$ & $\begin{array}{l}24,2 \mathrm{~kW}_{\mathrm{p}}\left(140 \mathrm{~m}^{2}\right) \mathrm{PV}+\text { passive } \\
\text { solar system in the facade }\end{array}$ & 28,605 & $\begin{array}{l}\text { District Heating } \\
\text { (from biomass) }\end{array}$ & \\
\hline
\end{tabular}

Table 7 gives an overview of the lighting-, cooling- and ventilation systems. All buildings except for the Office and Workshop ISE, implemented measures for improved lighting (increased use of daylight and/or energy efficient lighting).

All the office buildings installed some form of cooling system, and all the buildings installed a mechanical ventilation system. For buildings without an active cooling system, nighttime cooling with the mechanical ventilation system was used.

Buildings with ground heat pumps also use wells for free-cooling during summertime. At the Powerhouse Kjørbo, this system worked very well during the very hot summer of 2014. Chilled water from the wells covered all the cooling demand. 
Table 7 Description of lighting-, cooling- and ventilation system

\begin{tabular}{|c|c|c|c|}
\hline & Lighting & Cooling & Ventilation system \\
\hline $\begin{array}{l}\text { Tax Directorate Office } \\
\text { Building (NO) }\end{array}$ & $\begin{array}{l}\text { A new lighting system } \\
\text { with the LENI number } \\
\text { of } 9 \mathrm{kWh} / \mathrm{m}^{2} / \mathrm{y}\end{array}$ & $\begin{array}{l}\text { The central cooling of inlet air replaced by } \\
\text { central air condition with mechanical } \\
\text { ventilation and cooled beams in areas with } \\
\text { high internal loads. }\end{array}$ & VAV \\
\hline Powerhouse Kjørbo (NO) & & $\begin{array}{l}\text { Free cooling from wells, heat pump in } \\
\text { reverse for extra high cooling demand. }\end{array}$ & $\begin{array}{l}\text { Displacement ventilation, } \\
\text { efficient heat recovery, and } \\
\text { very low SFP. }\end{array}$ \\
\hline $\begin{array}{l}\text { Office and Workshop } \\
\text { Building Fraunhofer ISE } \\
\text { Campus (DE) }\end{array}$ & $\begin{array}{l}28,5 \mathrm{~kW} \text { (boat), } \\
33,5 \mathrm{~kW} \text { (butterfly) }\end{array}$ & $\begin{array}{l}\text { No cooling system installed, ventilation } \\
\text { also used for night cooling. }\end{array}$ & $\begin{array}{l}\text { A new ventilation system with } \\
\text { heat recovery for the office } \\
\text { floor added. }\end{array}$ \\
\hline $\begin{array}{l}\text { Printing workshop and } \\
\text { office building (DE) }\end{array}$ & $\begin{array}{l}\text { Enhanced use of } \\
\text { daylight, optimized } \\
\text { lighting }\end{array}$ & $\begin{array}{l}\text { Direct cooling via geothermal system. In } \\
\text { periods with high cooling demand, the heat } \\
\text { pumps in reverse. }\end{array}$ & $\begin{array}{l}\text { New mechanical ventilation } \\
\text { system, } 65 \% \text { heat recovery }\end{array}$ \\
\hline TU Vienna Plus Energy (AU) & LED & $\begin{array}{l}\text { Nighttime ventilation and external shading } \\
\text { combined with thermal activation of } \\
\text { components and a high efficient cooling } \\
\text { unit. }\end{array}$ & $\begin{array}{l}\text { Two centralized ventilation } \\
\text { systems, Air Handling Unit } \\
\text { (regenerative heat recovery } \\
\text { with rotary heat exchangers). }\end{array}$ \\
\hline $\begin{array}{l}\text { Office Building Roskilde } \\
\text { (DK) }\end{array}$ & $\begin{array}{l}\text { Energy efficient } \\
\text { lighting system }\end{array}$ & $\begin{array}{l}\text { The ventilation system located in a } \\
\text { separate building with capacity of } 80 \mathrm{~kW} \\
\text { cooling to the building. }\end{array}$ & $\begin{array}{l}\text { The ventilation system was } \\
\text { replaced, new system with } \\
\text { heat recovery rate of } 82 \% \text {. }\end{array}$ \\
\hline Schüco Headquarter (IT) & LED & $\begin{array}{l}\text { Solar absorption chiller ( } 15 \mathrm{kWf} \text { ) in addition } \\
\text { to the existing chillers ( } 536 \mathrm{KWf} \text { ). }\end{array}$ & $\begin{array}{l}\text { Air handling system (offices } \\
\text { and canteen). }\end{array}$ \\
\hline $\begin{array}{l}\text { Rockwool office building } \\
\text { (DK) }\end{array}$ & $\begin{array}{l}\text { T8 lights was replaced } \\
\text { by more efficient } \mathrm{T5} \\
\text { lights. }\end{array}$ & Part of the ventilation. & $\begin{array}{l}\text { Existing ventilation system } \\
\text { without heat recovery, } \\
\text { replaced by system with heat } \\
\text { recovery }(84 \%) \text { and cooling. }\end{array}$ \\
\hline $\begin{array}{l}\text { Solbråveien office centre } \\
\text { (NO) }\end{array}$ & $\begin{array}{l}\text { Floor lamps with } \\
\text { daylight and presence } \\
\text { control }\end{array}$ & $\begin{array}{l}\text { The existing cooling tower and ice water } \\
\text { machine replaced with heat pump/cooling } \\
\text { machine. }\end{array}$ & $\begin{array}{l}90 \% \text { of ducts reused, demand } \\
\text { controlled ventilation, active } \\
\text { supply air terminal devices. }\end{array}$ \\
\hline $\begin{array}{l}\text { Administration Building } \\
\text { Bruck/Mur (AT) }\end{array}$ & $\begin{array}{l}\text { A new lighting system } \\
\text { with the LENI number } \\
\text { of } 9 \mathrm{kWh} / \mathrm{m}^{2} / \mathrm{y}\end{array}$ & $\begin{array}{l}\text { A bivalent heat pump with a deep drilling } \\
\text { system is used for cooling and part of } \\
\text { heating. }\end{array}$ & $\begin{array}{l}\text { New ventilation system with } \\
\text { highly efficient heat recovery. }\end{array}$ \\
\hline
\end{tabular}


In the building of the Norwegian Tax Authority Oslo, a new lighting system with the LENI number of 14 $\mathrm{kWh} / \mathrm{m}^{2}$ (44\% reduction) was installed. The previous CAV system was replaced with a VAV mechanical system. Direct electric resistance heaters were changed to a new water-based heating system. The central cooling of inlet air for mechanical ventilation was replaced by central air-conditioning mechanical ventilation and cooled beams in areas with high internal loads. After the renovation, the central electrical boiler for hot water supply also utilizes the waste heat from a computer room in the basement in combination with the district heating.

In the Powerhouse Kjørbo, the old radiator system under each window is replaced by air heating for the ventilation system combined with a few radiators in the center of the building. The displacement ventilation system also provides some demandcontrolled cooling. The source of energy is a ground heat pump in combination with a $310 \mathrm{~kW}$ PV. A new lighting system with the LENI number of $9 \mathrm{kWh} / \mathrm{m}^{2}$ was installed. Calculation shows that the energy demand for ventilation has been reduced by $90 \%$ compared to a regular new building. The air velocity in the ducts was reduced to $0.5-1 \mathrm{~m} / \mathrm{s}$ (regular design $10 \mathrm{~m} / \mathrm{s}$ ). This will make a big difference in the energy demand because energy needed to the fans is proportional to the third power of the air velocity. If the air velocity is reduced by $50 \%$, the energy demand will be reduced

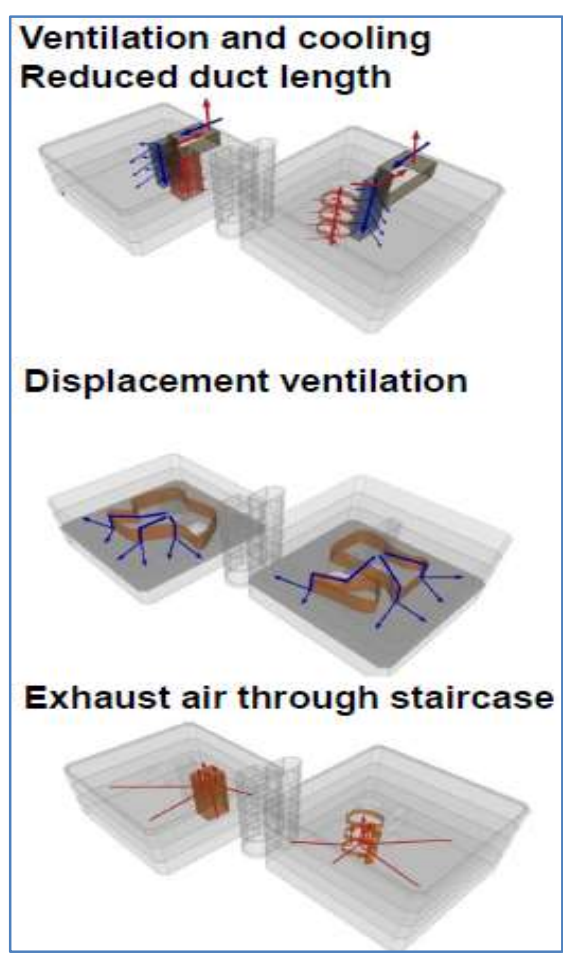

Figure 14 Ventilation system Powerhouse Kjørbo approximately by $90 \%$.

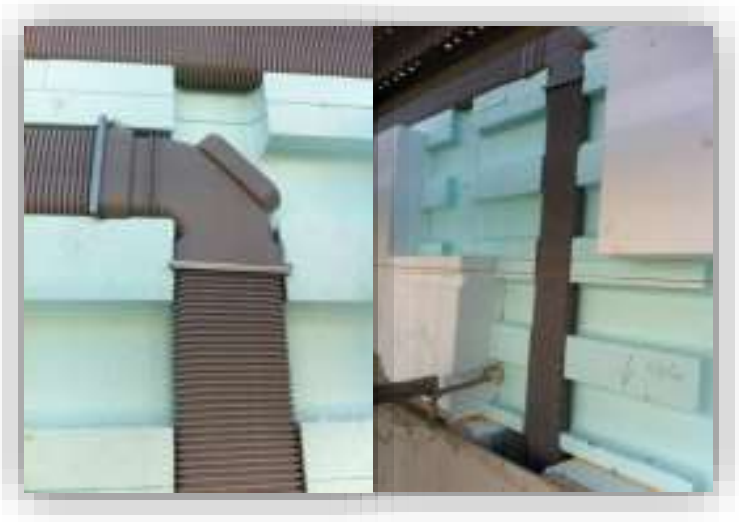

Figure 15 Façade insulations systems including air ducts
In the Office and Workshop Building Fraunhofer ISE Campus the ventilation ducts are included in the prefabricated wall insulation layer. This solution will be evaluated through the R\&D projects. A new ventilation system with heat recovery for the office floor was added. No cooling system installed, ventilation also used for night cooling. Southeast façade was prepared for the façade-integrated PV system.

\section{The heating of the Printing Workshop and Office} building was previously based on a gas boiler. After the renovation, the heating is based on a ground heat pump system with 12 wells ( $60 \mathrm{~m}$ deep). The waste heat from the printing workshop is also recovered. The old gas boiler is used as a backup and radiators are used to distribute the heat in the building. Before the renovation, there was no cooling or mechanical ventilation in the building. A new mechanical ventilation system with $65 \%$ of the heat recovery rate was installed, nighttime ventilation system and free cooling from the wells. In periods with high cooling demand, the heat pump is used in reverse. There were also installed radiant cooling panels with integrated phasechange materials (PCM) and a solar shading system. 
The TU Vienna Plus Energy building has two centralized ventilation systems, one for the floors 3 to 6 and the second for 7 to 10 (office use), and additional ventilation for toilets. An air-handling unit (regenerative heat recovery with rotary heat exchangers) was installed. A passive cooling system combined with thermal activation of components and a high efficient cooling unit was installed. A façade integrated PV system (336kWp) produces electricity. Optimization of all technical devices reduces the electricity demand. District heating and two electric boilers (DHW) deliver heat to the building.

The energy savings of $90 \%$ are achieved by:

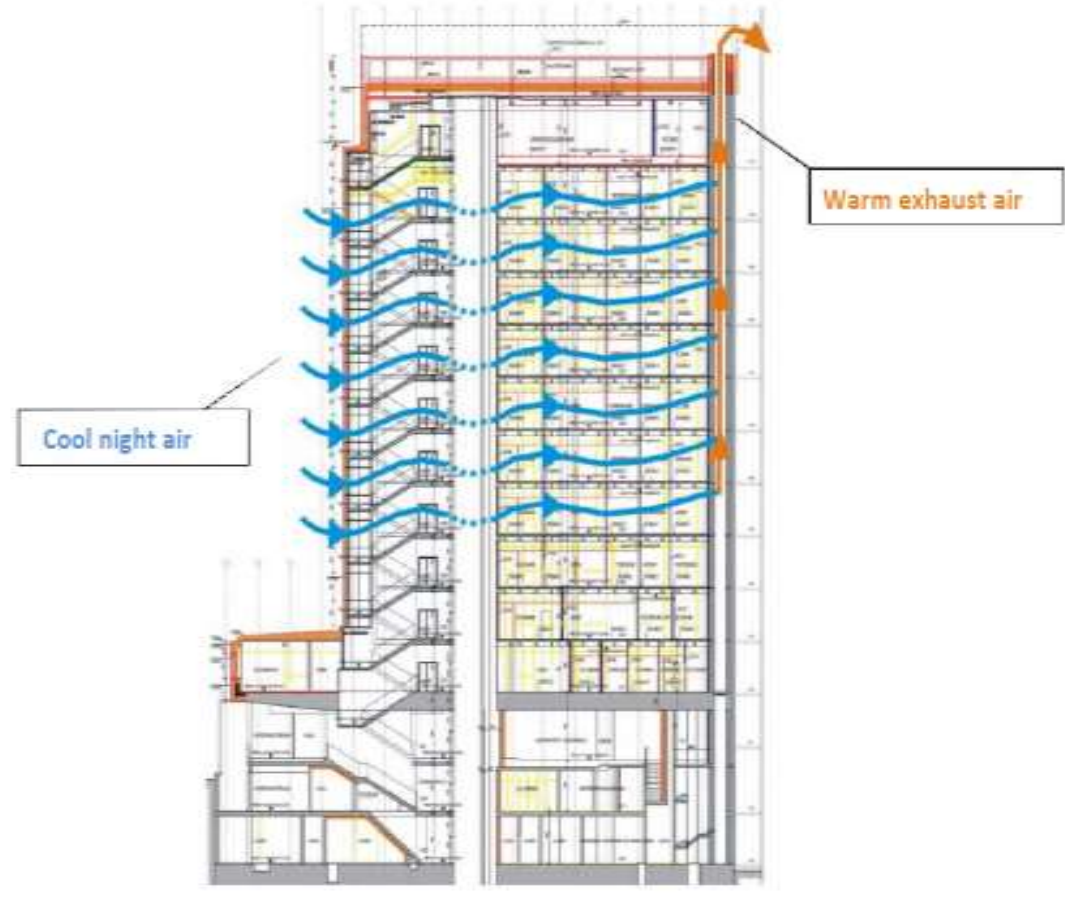

Figure 16 Cooling system TU Vienna Plus Energy building

- optimization of ultra-efficient building service components with low electricity consumption in standby and operation mode;

- smart electricity grid ensures negligible stand-by power consumption;

- enhanced use of daylight and optimized lighting;

- ultra efficient ventilation system with optimal heat and moisture recovery;

- temperature adjustment within the rooms by highly efficient thermo-active building systems;

- nighttime ventilation and thermal activation of components .

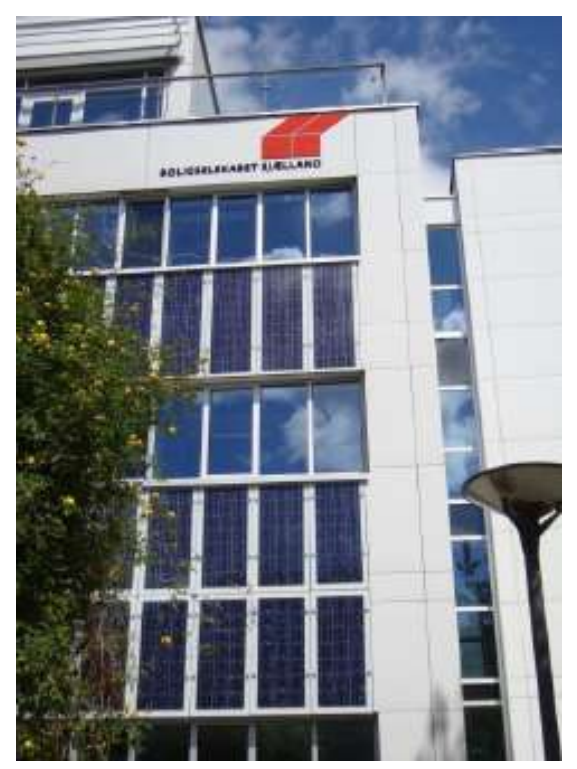

Figure 17 Façade integrated PV system, Office Building Roskilde
The heating of the Office Building, Roskilde is based on district heating (both before and after the renovation). Distribution system and radiators were changed. The entire ventilation system was replaced during the energy renovation. The new system has a heat recovery rate of $82 \%$. The ventilation system is located in a separate building and has the capacity to deliver $80 \mathrm{~kW}$ cooling for the building before the working hours. A separate free cooling system for the server room and individual printer rooms was also added. For power production, $130 \mathrm{~m}^{2} \mathrm{PV}$ panels were added to the southern facade of the building. The PV panels produce only a relatively small amount of electricity compared to the overall electricity use in the building. However, the PV panels also serve as part of the aesthetic appearance of the building and give the impression of a modern building that also signals the green profile of the company. 
The Schüco Italia Headquarters building has an overall design strategy for real life demonstration of Schüco components and technologies. Energy efficient lighting system was installed, the existing condensing boiler (615 kW) was supplemented with ground heat pump (17 kW) and $10 \mathrm{~m}^{2}$ integrated solar panels. An absorption chiller (15 KWf) connected to $45 \mathrm{~m}^{2}$ of solar collectors is installed in addition to the existing chillers (536 KWf). A $600 \mathrm{~kW}_{\mathrm{p}}$ PV plant is installed on the warehouse's roof and a $3 \mathrm{~kW}_{\mathrm{p}} \mathrm{PV}$ clad double skin (thin-film) was added to the bow-windows façade.

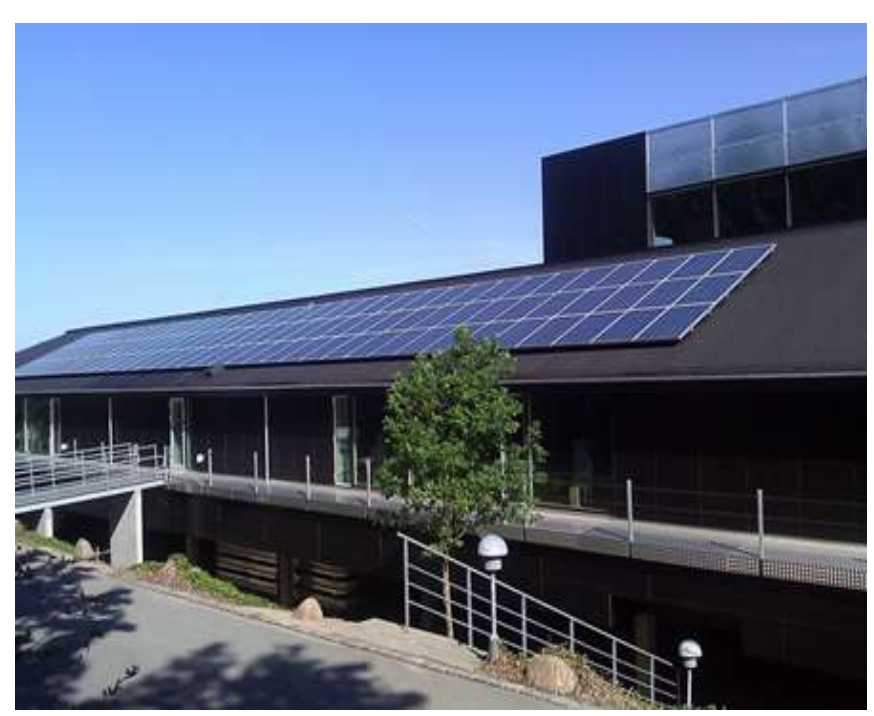

Figure 18 PV system Rockwool International Office Building "Center 2"
New LED lighting and other low energy lighting systems were installed in the Rockwool International Office Building "Center 2". The existing electric heating system was replaced with ground-coupled heat pumps $(2 \times 75 \mathrm{~kW})$ with 15 $x 120 \mathrm{~m}$ deep wells. The existing ventilation without heat recovery was replaced with a system with a heat recovery rate of $84 \%$ and cooling. Indoor climate is Class A, according to the national Danish standard on indoor climate. There are openings for natural ventilation in the top of the building. A solar collector for hot water supply was installed and a $170 \mathrm{~m}^{2} \mathrm{PV}$ system was installed.

In Solbråveien office center existing ducts and active supply air terminal devices is utilized. Constant airflow (CAV) replaced with demand controlled ventilation (VAV) with active supply air terminal devices. The ventilation has heat recovery (85\%) and low SFP. The existing shafts were used. $90-95 \%$ of the ventilation ducts were cleaned. The ventilation system uses active air supply with integrated regulation using detectors and temperature sensors. The existing cooling tower and ice water machine are replaced with heat pump/cooling machine. There is demand control installed for the lighting system, and the T8 lights were replaced by T5 lights. Existing electric heater was replaced with an air/water heat pump and old electric ovens were replaced with more effective demand-controlled heaters.

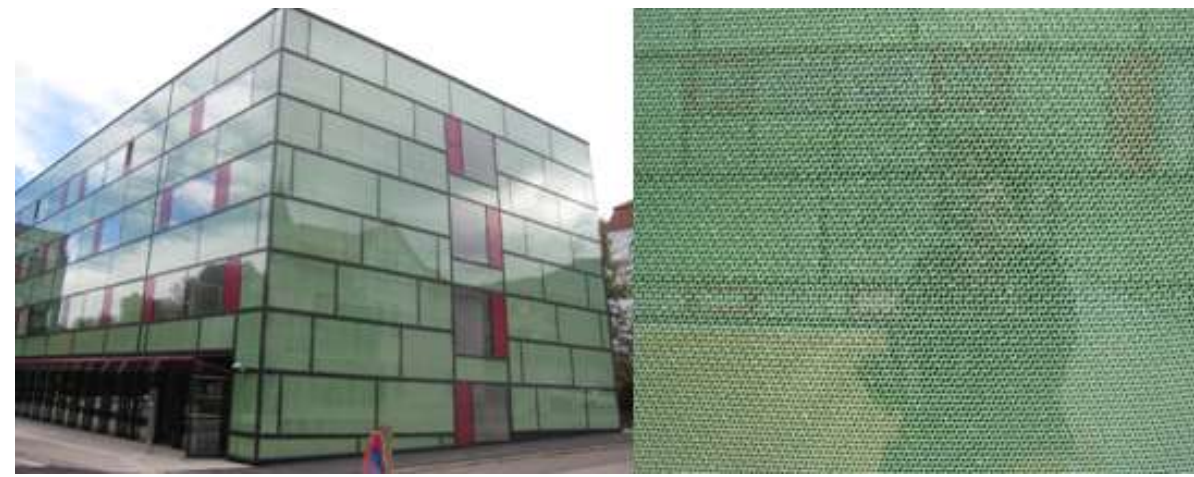

Figure 19 Passive solar comb in facade of Administration .building Bruck/Mur
In the administration Building Bruck/Mur District Court and Fiscal Office a new ventilation system with highly efficient heat recovery was installed in the wing of the district court.

A bivalent heat pump with a deep drilling system is

used for cooling and a part of heating. For the remaining heating, district heating based on biomass is used, for the hot water supply, decentralized electric boilers are installed. A passive solar comb system is 
integrated in the façade, see Figure 19. The lighting concept is based on the floor lamps with daylight and presence control. A $140 \mathrm{~m}^{2} \mathrm{PV}$ system is installed on the roof.

\subsection{Energy}

Table 8 shows the reduction in reported energy use for different office buildings. It is not possible to compare the energy result due to a variety in reported energy numbers. The office building in Roskilde changed conditions after the renovation and therefore it is not possible to compare the before and after situation. Together with the Office and Workshop ISE, the energy numbers for these buildings before the renovation are not reported, and it is therefore not possible to calculate a reduction in energy use.

All of the office buildings that have reported their energy use before the renovation reduced their energy use by more than $40 \%$. The two plus/powerhouses show the best result, with $90 \%$ reduction even before the energy supply from the PV system is included.

Table 8 Energy use office buildings [ $\left.\mathrm{kWh} / \mathrm{m}^{2}\right]$

\begin{tabular}{|c|c|c|c|c|}
\hline & $\begin{array}{c}\text { Before } \\
{\left[\mathrm{kWh} / \mathrm{m}^{2}\right]}\end{array}$ & $\begin{array}{c}\text { After } \\
{\left[\mathrm{kWh} / \mathrm{m}^{2}\right]}\end{array}$ & Reduction & Description \\
\hline $\begin{array}{l}\text { Tax Directorate Office Building } \\
\text { (NO) }\end{array}$ & 174 & 88 & $50 \%$ & Total net energy demand (incl. Appliances). Calculated. \\
\hline Powerhouse Kjørbo (NO) & 210 & 20 & $90 \%$ & $\begin{array}{l}\text { Annual delivered energy, without data and technical } \\
\text { equipment. PV not included. Calculated. }\end{array}$ \\
\hline $\begin{array}{l}\text { Office and Workshop Building } \\
\text { Fraunhofer ISE Campus (DE) }\end{array}$ & n.a & 337 & - & Primary energy use. Calculated. \\
\hline $\begin{array}{l}\text { Printing workshop and office } \\
\text { building (DE) }\end{array}$ & 320 & 135 & $58 \%$ & Heating, cooling, ventilation and lighting. \\
\hline TU Vienna Plus Energy (AU) & 358 & 36 & $90 \%$ & $\begin{array}{l}\text { Calculated energy consumption not including energy } \\
\text { production from PV }\left(29 \mathrm{kWh} / \mathrm{m}^{2}\right) \text {. }\end{array}$ \\
\hline Office Building Roskilde (DK) & n.a. & 112 & - & $\begin{array}{l}\text { Heat and DHW use + electricity including production from } \\
\text { PV. Total energy use including aux. energy and cooling for } \\
\text { copy/printers room. Measured. }\end{array}$ \\
\hline Schüco Headquarter (IT) & 97 & 61 & $37 \%$ & Heat in primary energy. Calculated. \\
\hline Rockwool office building (DK) & 264 & 41 & $84 \%$ & Primary energy, incl. extension. Calculated. \\
\hline Solbråveien office (NO) & 204 & 64 & $69 \%$ & Total net energy. Calculated. \\
\hline $\begin{array}{l}\text { Administration Building } \\
\text { Bruck/Mur (AT) }\end{array}$ & 153 & 24 & $84 \%$ & $\begin{array}{l}\text { Heating demand. Prim. Energy demand reduced by } 65 \% \text {. } \\
\text { Calculated. }\end{array}$ \\
\hline
\end{tabular}

Two of the buildings achieved passive house level, and two buildings achieved low energy standard.

For the Norwegian Tax Authority Oslo the primary energy consumption before the renovation, which includes technical office equipment (PC, copy machines etc.), was measured/estimated to $170 \mathrm{kWh} / \mathrm{m}^{2}$. The overall saving target was a reduction of $60 \%$. The primary energy demand was reduced to 84 $\mathrm{kWh} / \mathrm{m}^{2}$, corresponding to a $51 \%$ reduction. This includes $34,5 \mathrm{kWh} / \mathrm{m}^{2}$ for office equipment.

The Powerhouse Kjørbo is a powerhouse. A powerhouse is defined as a building that during its lifecycle produces more renewable energy than it consumes for the production of building materials, construction, operation and demolition of the building. Energy use for electrical appliances shall not be included in the energy balance account. For the life cycle calculation, 60 years timespan is used. The annual delivered energy before the renovation was $240 \mathrm{kWh} / \mathrm{m}^{2}$ including data facilities. The calculated primary energy 
demand for operational use is $29.8 \mathrm{kWh} / \mathrm{m}^{2}$ after the renovation, and embodied energy is now 22.1 $\mathrm{kWh} / \mathrm{m}^{2}$ while the primary energy supply from the PV system is $69 \mathrm{kWh} / \mathrm{m}^{2}$.

The renovated Office and Workshop Building Fraunhofer, ISE Campus, together with the adjacent new building, are part of a joint energy- heating and cooling system. A research project will evaluate the

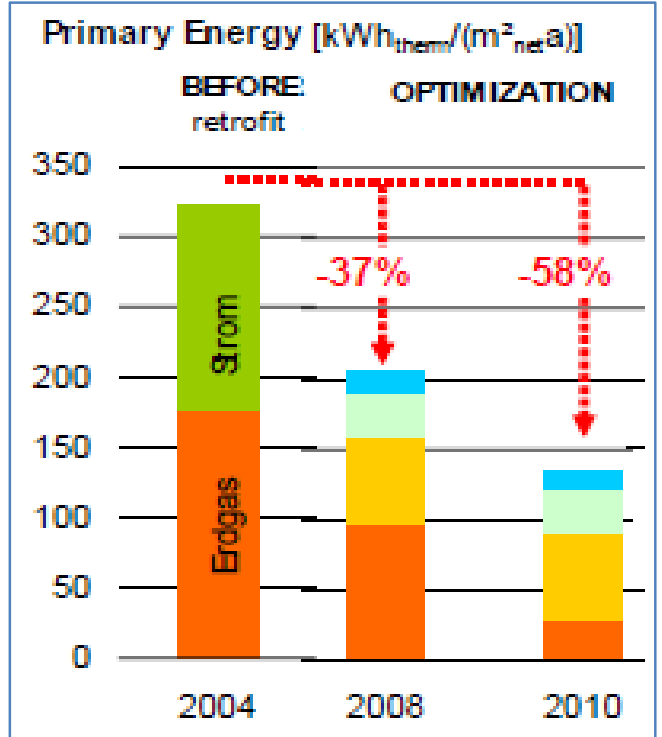

Figure 20 Reduction in primary energy performance, Printing Workshop and Office building energy flow within the system and between the buildings. In the new building there is a cold water storage installed to buffer energy in related temperature levels. Both buildings will be the first step of an overall integrated energy grid of all Fraunhofer campus buildings.

Before the renovation, the energy use in the Printing Workshop and Office building was $134.5 \mathrm{kWh} / \mathrm{m}^{2}$. After the renovation, including some optimization measures, the energy use was reduced by $58 \%$ to $56.5 \mathrm{kWh} / \mathrm{m}^{2}$, see Figure 20

The TU Vienna Plus Energy building produces more energy than it consume over a year. Before the renovation (2009), the building used 2,067 MWh electricity and $677 \mathrm{MWh}$ heat. It is calculated that after the renovation, the electricity consumption is approximately $226 \mathrm{MWh}$, the heat consumption is approximately $48 \mathrm{MWh}$ and the total energy demand of the building is reduced by $90 \%$. The PV-system will produce approximately $226 \mathrm{MWh}$ per year.

For the Office building, Roskilde there is no available data on the energy use before the renovation. The measured energy use in 2012 (after renovation) shows that energy consumption for heating and domestic hot water was $61 \mathrm{kWh} / \mathrm{m}^{2}$, and the electricity use was $55 \mathrm{kWh} / \mathrm{m}^{2}$. Electricity production from the PV panels was $3.6 \mathrm{kWh} / \mathrm{m}^{2}$. The electricity consumption includes auxiliary energy, cooling compressor in the ventilation system and electricity for copy and printer rooms. This has influenced the heat balance, and the radiators are now redundant. This in turn has given rise to a problem with draught from the windows since radiators no longer counteract the cool surfaces of the windows.

For the Schüco Italia Headquarters there is no measured data on the energy consumption of the original building available, and it is difficult to split the energy consumption between the renovated building and the new building. Calculations show that the primary energy heat consumption is reduced from 97.0 to $61.5 \mathrm{kWh} / \mathrm{m}^{2}$. The PV power production is approximately $650,000 \mathrm{kWh} / \mathrm{y}$, which covers the total demand for electricity over the year. The primary energy demand for electricity is thus considered zero.

The total calculated net energy in Solbraiveien office center, Asker was reduced by $64 \%$. This includes the energy use for appliances. The total calculated supplied energy was reduced by $69 \%$ from 204 to 64 $\mathrm{kWh} / \mathrm{m}^{2}$. The building achieved class B in the Energy Building Performance Certification, and yellow in the Norwegian heating grade (62\% use of direct electricity).

Even though comfort and user convenience in the administration Building Bruck/Mur - District Court and Fiscal Office increased significantly, and therefore additional energy consumption in ventilation and cooling occurred, the primary energy demand was reduced. Before the renovation, the building had a 
heating energy demand of $153 \mathrm{kWh} / \mathrm{m}^{2}$. After the renovation, the district court had a heating energy demand of $22.9 \mathrm{kWh} / \mathrm{m}^{2}$, and the Ministry of Finance/BEV had a heating energy demand of $25.6 \mathrm{kWh} / \mathrm{m}^{2}$. The primary energy demand was reduced by $65 \%$.

\subsection{Economy}

The table shows the cost of renovation per square meter heated area. It is difficult to compare the numbers because the given categories of costs for the different project are not the same, and some projects have not given any data on the costs at all. Most of the projects have given information only about the total cost of the renovation.

Table 9 Renovation costs in office buildings

\begin{tabular}{|c|c|c|c|}
\hline Building & Costs $€ / \mathrm{m}^{2}$ & Comment & $\begin{array}{l}\text { Public } \\
\text { funding }\end{array}$ \\
\hline Tax Directorate Office Building (NO) & 116 & Extra cost for $\mathrm{PH}$ standard, funding not included & $X$ \\
\hline Powerhouse Kjørbo (NO) & 2654 & Total cost not including VAT & $X$ \\
\hline $\begin{array}{l}\text { Office and Workshop Building Fraunhofer } \\
\text { ISE Campus (DE) }\end{array}$ & n.a. & $\begin{array}{l}432000 € \text { is the total cost for insulation, windows } \\
\text { and ventilation. }\end{array}$ & $x$ \\
\hline Printing workshop and office building (DE) & 1097 & Cost of construction + HVAC & \\
\hline TU Vienna Plus Energy (AU) & 2738 & Cost of total renovation & \\
\hline Office Building Roskilde (DK) & 1932 & Cost of total renovation & $X$ \\
\hline Schüco Headquarter (IT) & 1120 & Cost of total renovation & \\
\hline Rockwool office building (DK) & 1300 & $\begin{array}{l}\text { Cost related to energy performance (including a part } \\
\text { of mold and fungi repair) Total cost: } 2242 € / \mathrm{m} 2\end{array}$ & \\
\hline Solbråveien office centre (NO) & 1386 & Cost of renovation & $x$ \\
\hline $\begin{array}{l}\text { Administration Building Bruck/Mur - } \\
\text { District Court and Fiscal Office (AT) }\end{array}$ & & n.a & \\
\hline
\end{tabular}

The Norwegian Tax Authority Oslo building received public funding of $60 \%$ of the extra investment to improve the energy design from the minimum stipulated in the building codes to a level $50 \%$ lower. The project have been granted a maximum funding of $€ 2.400 .000$. The extra costs for increasing the energy standard beyond the Norwegian Standard Building Code (TEK10) to PH standard and energy label A, is $€$ 4.060.000. Using an energy cost of 0,125 $€ / \mathrm{kWh}$, gives the payback time of 5-11 years with or without the government grant.

The Powerhouse Kjørbo is to be built within commercial marketable conditions. It has been granted 2.000.000 € from government funding. The rent is higher than for a similar office building with an average energy standard. However, when the reduced energy costs are included, the total cost for the tenant is at about the same level as for a standard office building.

The Office and Workshop Building Fraunhofer, ISE Campus, is owned by the Fraunhofer society and therefore is mainly financed by the government. Financial support was also given by a public market support program and a government financed research project was linked to the retrofitting work. Cost of insulation work is $150 \mathrm{k} €$, windows $270 \mathrm{k} €$ and ventilation $12 \mathrm{k} €$ (all ex VAT).

For the Printing Workshop and Office building the construction cost for the project was $860 € / \mathrm{m}^{2}$ and the cost for the ventilation system was $370 € / \mathrm{m}^{2}$. The total cost for the renovation was $1230 € / \mathrm{m}^{2}$. 
The total cost for the renovation was 21 million Euro for the TU Vienna Plus Energy building. The additional cost for the plus energy standard was financed by TU Vienna and financially supported by two Austrian ministries and the city of Vienna.

The Office building, Roskilde had a total cost for the renovation of approximately $4.8 \mathrm{M} €$, or $1,932 € / \mathrm{m}^{2}$. The owner of the building, Boligselskabet Sjælland financed the renovation, with energy subsidies for the insulation of the facade and installation of the PV panels (agreement with energy companies).

For the Schüco Italia Headquarters the total renovation cost was $7.2 \mathrm{M€}(+0.8 \mathrm{M€}$ for the automated warehouse). The cost for the renovation of the existing building was approximately $1.7 \mathrm{M} €\left(1120 € / \mathrm{m}^{2}\right)$, and the cost for the new built was approximately $5.6 \mathrm{M} €\left(2000 € / \mathrm{m}^{2}\right)$.

The total cost of the renovation of the Rockwool International Office Building "Center 2" was $2242 € / \mathrm{m}^{2}$. The part of the total cost that is directly related to the improvement in energy performance is approximately $1302 € / \mathrm{m}^{2}$. The total costs related to the energy renovation makes for the $58 \%$ of the total project cost. The energy renovation cost savings have a payback time of approximately 41 years.

The total cost for the renovation of Solbraiveien office center, Asker, was 14, 4 mill $€+$ tax. Approximately 1 million $€+$ tax was the additional cost for upgrading to EBPC class B. The project received public funding.

\subsection{Environment}

Different environmental results have been reported. Six of the buildings have been environmental classified; three of the buildings have used environmentally friendly materials. Several of the buildings have accounted for an improvement in the indoor environment. Only one building have complaints about the temperature. 
Table 10 Environmental indicators office buildings

\begin{tabular}{|c|c|c|c|c|c|c|}
\hline & $\begin{array}{l}\text { Improved } \\
\text { lighting } \\
\text { quality }\end{array}$ & $\begin{array}{l}\text { Improved } \\
\text { indoor } \\
\text { thermal } \\
\text { climate }\end{array}$ & $\begin{array}{l}\text { Improved } \\
\text { air quality }\end{array}$ & Acoustic & $\begin{array}{l}\text { Environmental } \\
\text { classified }\end{array}$ & Materials \\
\hline $\begin{array}{l}\text { Tax Directorate Office Building } \\
\text { (NO) }\end{array}$ & $x$ & $x$ & $\begin{array}{c}\mathrm{CO}_{2}<1000 \\
\mathrm{ppm}\end{array}$ & & BREEAM very good & Low emission \\
\hline Powerhouse Kjørbo (NO) & & $x$ & & & BREEAM outstanding & $\begin{array}{l}\text { Low emission/ } \\
\text { reuse }\end{array}$ \\
\hline $\begin{array}{l}\text { Office and Workshop Building } \\
\text { Fraunhofer ISE Campus (DE) }\end{array}$ & $x$ & & $x$ & & & \\
\hline $\begin{array}{l}\text { Printing workshop and office } \\
\text { building (DE) }\end{array}$ & $x$ & $\begin{array}{c}\text { Complaint } \\
\mathrm{s}\end{array}$ & $x$ & & & \\
\hline TU Vienna Plus Energy (AT) & $x$ & & $x$ & & Klima:aktiv Gold & $\begin{array}{l}\text { Ecological } \\
\text { materials }\end{array}$ \\
\hline Office Building Roskilde (DK) & & $x$ & & $x$ & & \\
\hline Schüco Headquarter (IT) & & $x$ & & & & \\
\hline Rockwool office building (DK) & $x$ & & $x$ & $x$ & $\begin{array}{l}\text { Energy label A, EEC- } \\
\text { ECO-life certificated } \\
\text { (voluntary industry } \\
\text { standard) }\end{array}$ & \\
\hline Solbråveien office centre (NO) & $x$ & $x$ & $x$ & & $\begin{array}{l}\text { Energy label: } \\
\text { Class B }\end{array}$ & $\begin{array}{l}\text { Reuse of vent. } \\
\text { ducts }\end{array}$ \\
\hline $\begin{array}{l}\text { Administration Building } \\
\text { Bruck/Mur (AT) }\end{array}$ & & & & & $\begin{array}{l}\text { TQB, , climate } \\
\text { protection certificate } \\
\text { "klima:aktiv Gold" }\end{array}$ & \\
\hline
\end{tabular}

The Norwegian Tax Authority Oslo is classified Very Good according to the BREEAM system. There has been a special focus on low emission materials. The $\mathrm{CO}_{2}$ level does not exceed $1000 \mathrm{ppm}$, and the daylight factor in working areas is equal to two.

In the Powerhouse Kjørbo, more than $90 \%$ of the waste from construction is reused or recycled. The building materials should have the lowest possible embodied energy. Surface burned wood is used for façade cladding. The BREEAM classification score is Outstanding. Better solar shading improves the indoor thermal climate.

In the renovated The Office and Workshop Building Fraunhofer, ISE Campus, the visual quality of the office workspace has improved as well as the air quality and the balanced temperature level. The comfort criteria are fulfilled and the performance of the façade integrated ventilation system - a demonstration project - is better than expected and will be monitored during operation. Improved indoor air quality was achieved by the installation of an AHU (Air Handling Unit) with filters and heat exchangers with humidity recuperation. The AHU can be individually controlled by the users. The visual quality of the office workspace has improved due to blinds with individual control functions.

In 2008, an evaluation of the indoor climate in the Printing Workshop and Office building revealed that the users of the building were satisfied with the air quality and the light conditions in the building. However, the users perceived the air temperature in the winter as cold and in the summer as warm. Due to the landscape office, the users cannot regulate the temperature individually. 
The TU Vienna Plus Energy building is certified by the Austrian Sustainable building control and has Class $B$ according to the Energy Building Performance Certification. Ecological materials were used in the renovation, and an LCA analysis was performed. The indoor air and lighting quality have improved. Solar energy is used, and passive measures reduce the energy demand.

In the Office building, Roskilde the indoor climate has improved significantly. Several measures to improve the acoustic indoor climate have been carried out, such as installation of special partition walls, special rubber coated floors and an acoustic ceiling. The improvements of the building envelope and the ventilation system have reduced the heat loss.

For the Schüco Italia Headquarters the thermal conditions during the summer have significantly improved after the renovation.

The old Rockwool International Office Building "Center 2" had an energy label F and the renovated building will have an A. The renovated building will also be EEC-ECO-Life certificated. The indoor climate is classified as class $A$ and the building is now equipped with two atriums and two green gardens. The lighting quality has improved with increased use of daylight and LED electrical lighting. The acoustic quality of the building has also improved.

The indoor climate in Solbråveien office center, Asker has improved, and a more stable and better indoor environment is achieved due to better temperature control, $\mathrm{CO}_{2}$-levels and lighting quality.

The Administration Building Bruck/Mur has received the Total-Quality-Building (TQB) certificate, which is the sustainability certificate of the Austrian Sustainable Building Council (ÖGNB - www.oegnb.net ). The certificate is different for the two building wings as the district court got 911 points, and the wing of the fiscal office got 741 points out of max 1.000 points. In addition, the building (the district court wing) holds the climate protection certificate "klima:aktiv Gold"

\subsection{Decision process}

For the Norwegian Tax Authority Oslo the project's initial objective was to refurbish the interior of the building, and energy was not at that time the main objective. At the start of the planning process, the energy goal was label B. Through a discussion/negotiation process with the building owner and users, the ambition was increased to energy label A / Passive house. The idea was launched in 2009 and the detailed project description completed in March 2011. The renovation was completed by the end of 2013.

For the Powerhouse, Kjørbo the idea came in 2011 to make a plus energy renovation. The focus during the design process has been the energy targets. A multidisciplinary team of experts from research, consultancy, architects, contractor and owner carried out a true Integrated Design Process. The renovation process was completed in March 2014.

The main incentives for the renovation of the Office and Workshop Building Fraunhofer, ISE Campus were to reduce the energy consumption, and improve the indoor climate. Because a new laboratory was built as an annex, a retrofitting of the old building was mandatory for an optimal function of the old and the new building. 
The Printing Workshop and Office building the renovation was done in two phases, with first phase in 2005 and second phase in 2011. The building was enlarged.

The TU Vienna Plus Energy building is part of the 'Univercity 2015'. The goal of this project is to bring high standards for energy efficiency to the university and to create an optimal environment for science and studying. The project is a flagship project in terms of energy efficiency and sustainable building due to the Austrian government's general refurbishment package for the renewal of universities and within the research and innovation program 'Building of Tomorrow - Haus der Zukunft'. The idea was born in 2009, the renovation started in April 2012, the renovation is expected to be completed in September 2014.

The main incentives for the renovation of the Office building, Roskilde was to reduce the energy consumption, improve the indoor climate and increase the office space. Also the owner of the building wanted to renew the expression of the building to better suit the company's green profile. The renovation was completed in 2010.

For the Schüco Italia Headquarters the idea was born in 2008, and the need for more space was the initial argument for the renovation. There was also a need for a space for training and a showroom. Another important aspect in the process was to use the same building components both in the new and in the refurbished building. The possibility to serve as an exemplary case project became more important during the process. The renovation was completed in October 2009.

The main incentives for the renovation of Rockwool International Office Building "Center 2" were to reduce energy consumption for the 34 years-old office building and to establish an attractive and up-todate working space for 120 employees. Furthermore, Rockwool wanted to focus on the challenges and possibilities in raising the energy standard in industrial constructions. The office space was outdated and the energy performance and indoor climate were far below the current standard. The aim of the renovation was to upgrade the energy performance to meet the future Danish low energy class 2015 for new buildings and to achieve a high quality office workspace. With a few more PV elements on the roof, the building would have fulfilled requirements of the Building Class 2020. The project was carried out by Rockwool International together with an architect and an engineer. There has been a close cooperation between all the departments in Rockwool, and the decision making process needed to take into account the requests and wishes of the individual actors while at the same time maintaining focus on the overall objective of the renovation.

The owner of Solbråveien office center, Asker wanted a retrofit "as good as possible." The first upgrade was made for the ventilation and the energy distribution systems, but limited to one section of the building. The decision of the envelope renovation was made later on. An integrated solar system in the façade was also evaluated, but the idea was abandoned due to the cost. A total enterprise contract with the building owner and subcontractors was signed. An important aspect was to established cooperation with the earlier projects of the same contractor. The idea was born in 2009, the first part of the renovation started in 2012 and the renovation was completed in 2014.

For the Administration Building Bruck/Mur, the idea was born in 2004 when the Ministry of Justice needed more space for the district court. In 2009, it was decided to implement a pilot project for the whole building including all three public stakeholders (the district court, the Ministry of Finance and BEV). 
An international architectural design competition was carried out. The renovation started in May 2011, and finished in September 2012.

\section{Historic and protected buildings}

Four of the buildings in the task are historic and protected buildings.

\subsection{Short introduction of the buildings}

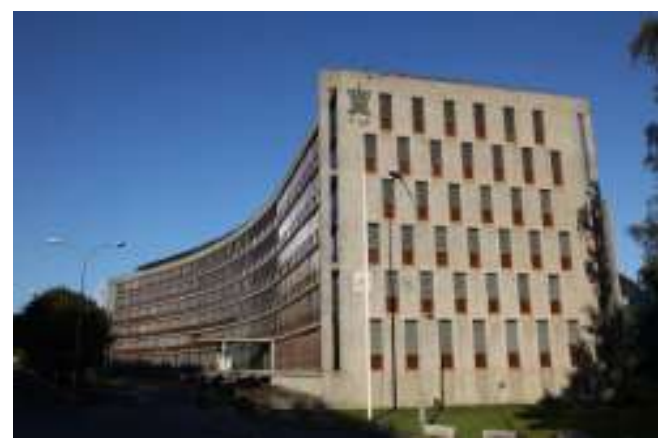

The Norwegian Energy Authority

The building was constructed in 1962-64 for the Energy

Authority. This is a monument and a cultural heritage building of post-war Norway. The building is listed as historic and has several protected elements, both inside the building and on the outer façades. The renovated floor area is $16880 \mathrm{~m}^{2}$.

\section{Osram Building}

The building was built in 1953 as an industrial building. It was the first prefabricated building in Copenhagen. It was built as an office and a warehouse for Nordisk Glødelampeindustri AS. The building is now in use as a Culture Centre.
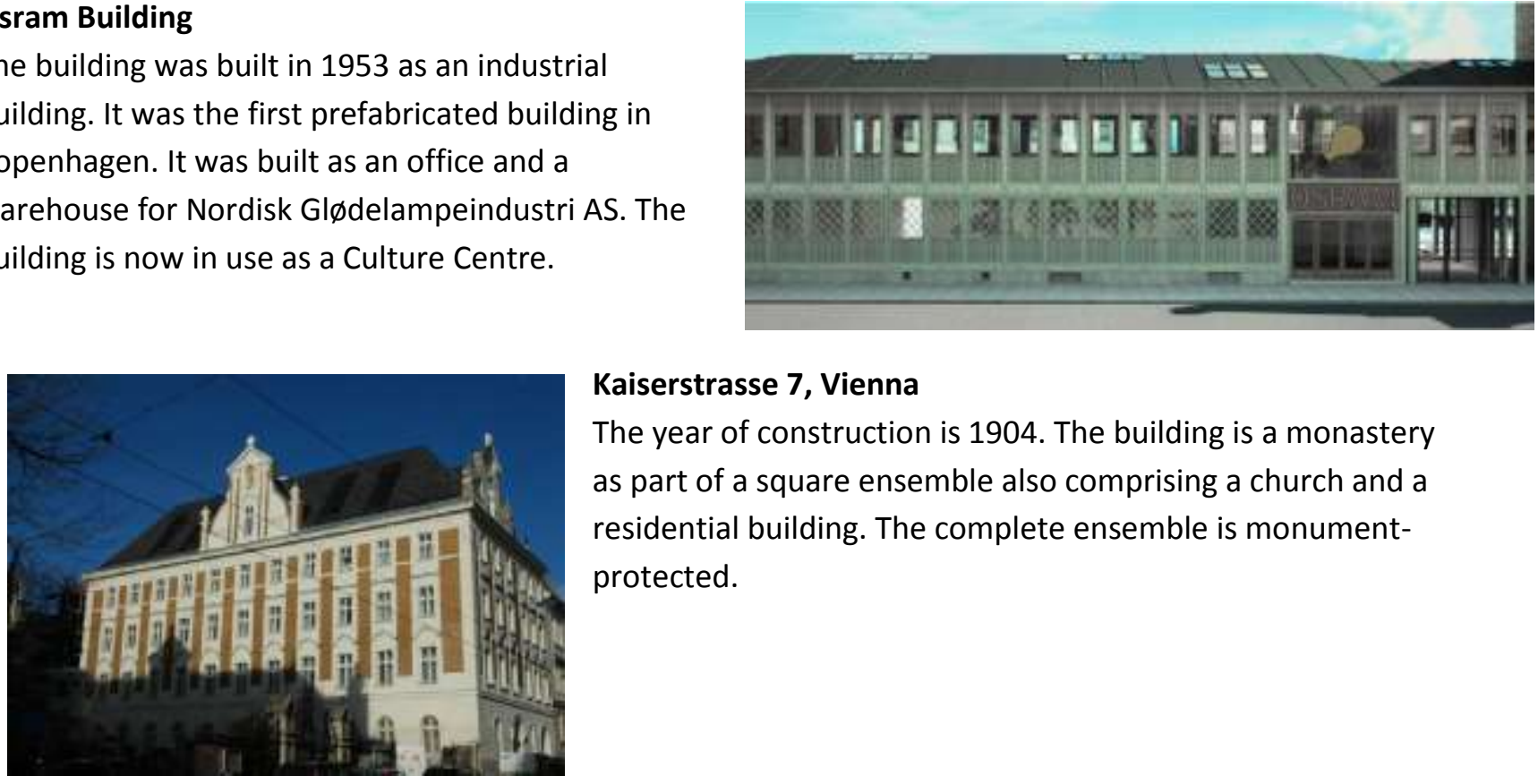

\section{Kaiserstrasse 7, Vienna}

The year of construction is 1904 . The building is a monastery as part of a square ensemble also comprising a church and a residential building. The complete ensemble is monumentprotected.

\section{Kampen School in Oslo}

This is a listed school from 1888. The building was renovated in 1978 and the windows were changed in 1998. A general renovation took place in 2003. The main idea was to demonstrate new concepts for energy efficient ventilation and lighting. The total floor area is $4500 \mathrm{~m}^{2}$.

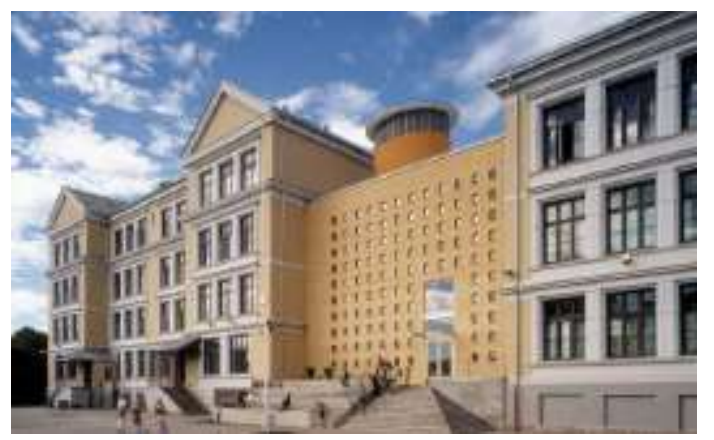




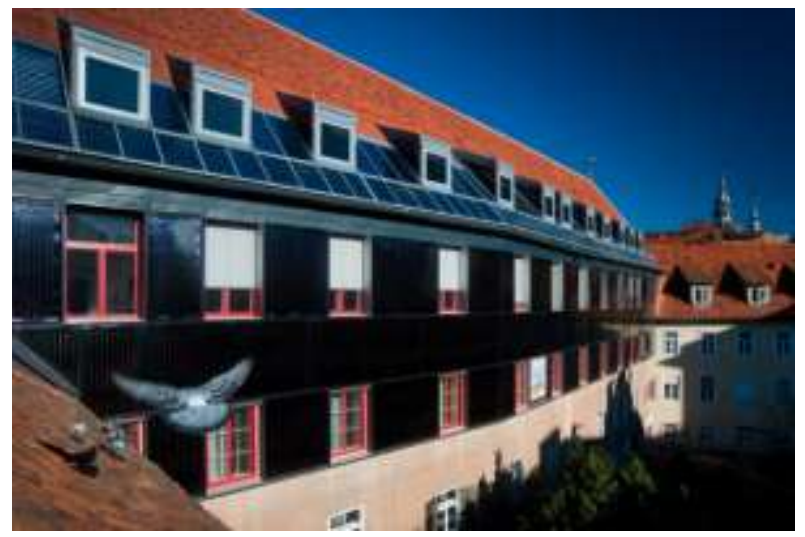

\section{Franciscan Monastery in Graz}

This is a medieval building structure and it is parts of the historic city walls. The first part of the building was built in 1239, and the main parts were built from 1250 to 1650 . The building is protected. Today the building is used as church, monastery, library, harborage, emergency accommodation. This means that the building is partly open to the public. The building is also housing 13 friars and students of theology. The objective of the renovation was to conserve and preserve the building, reduce the heating costs, and add new modern functions such as meeting rooms, conference center, event rooms, etc.

\subsection{Envelope}

Three of the buildings implemented measures for improvement of the building envelope, but only the Franciscan Monastery included measures for the floor/slab.

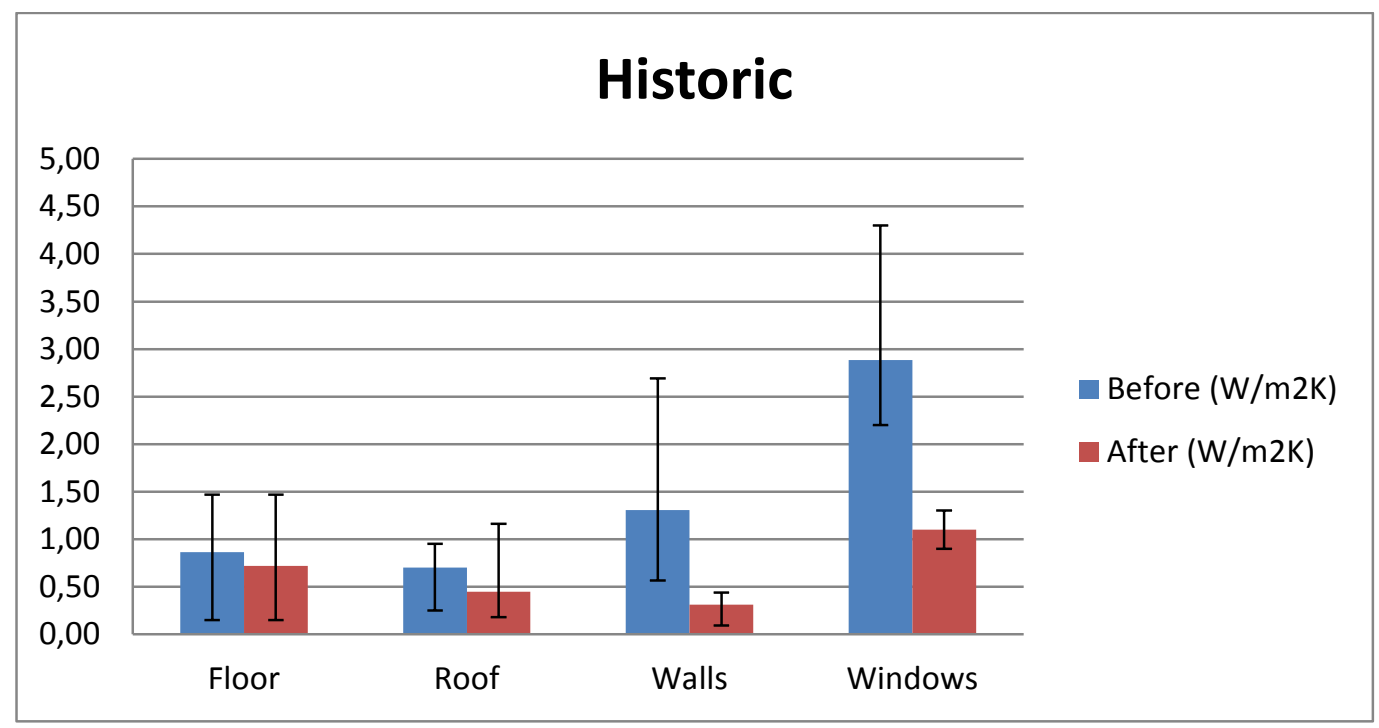

Figure 21 Average, minimum and maximum $U$-values $\left(\mathrm{W} / \mathrm{m}^{2} \mathrm{~K}\right)$ for the historic and protected buildings

The figure shows that the windows have the greatest absolute change in U-value and the walls have the greatest relative change. The measures on Kampen School are not included because the building envelope was kept as-built, but a new building was built between the two existing buildings. 


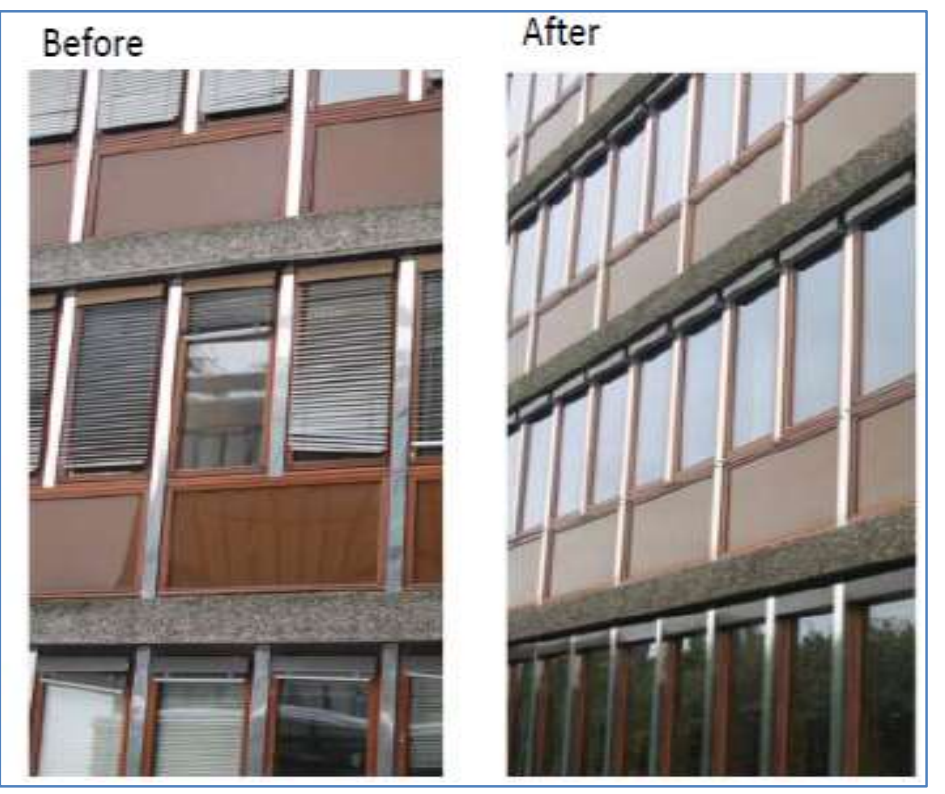

Figure 22 New windows and façade for the Norwegian Energy Authority Building
Elimination of the thermal bridges was a focus of the renovation of The Norwegian Energy Authority building, and the overall thermal bridge value was calculated to be $0.09 \mathrm{~W} / \mathrm{m}^{2} \mathrm{~K}$. . The air tightness of this building was measured to be $0.8 \mathrm{~h}^{-1}$. The building included measures for the roof/attic and the walls. Added insulation in the walls and sealing under and between windows. The wall under the windows, which included protected teak panels, was updated with added insulation in the outer wall behind the radiators. New windows with external shading were installed.

The ground floor ceiling in the Osram building was removed to double the room height in a part of the entrance and to improve availability of the daylight. Glazed indoor walls in the upper part were installed to avoid glimpsing, while still improving the daylight. Roof windows above the great hall were supplied with automatically operated sunscreens and opening devices for natural ventilation in offices and a hallway on the first floor. Inner insulation was added to the protected façade on the ground floor using floor-to-ceiling energy glass. Inner insulation was added to the protected façade on the first floor using mineral wool and plasterboards. Outer insulation was added to the façade towards the garden using mineral wool and hard pressed mineral cover plates. New thin frame windows with the energy glass were installed and single glass was replaced by double energy glass in the original teak wood frame of the main entrance.

In Kaiserstrasse 7 in Vienna a good energy performance was achieved by reducing the heat losses through the walls and windows of the building stock, a high standard attic conversion and innovative window solution. The insulation was placed on the inner side of the walls.

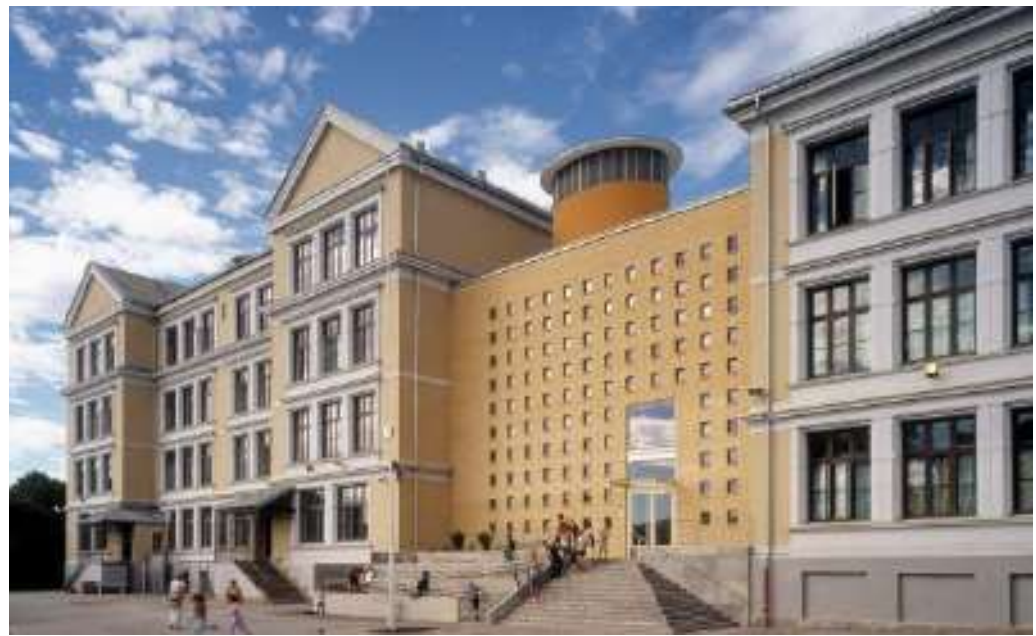

The building envelope of the

Kampen School in Oslo was kept as built, but a new building was built between the two existing buildings. By doing this, the energy demand per square meter of the surface area for the total school building was reduced. 
For The Franciscan Monastery in Graz a four level vision for the renovation had been developed, where the first step was to reduce the energy consumption by energy efficiency measures. Measures that were implemented are: desiccation of the walls, insulation where possible, rooms used as buffers, renovation of box-type windows, warming tints. Savings after this step were calculated to reach $25 \%$ of the energy demand.

\subsection{Technical system}

As shown in Table 11, three of the buildings are connected to the district heating. Only the Osram Culture Centre and the Franciscan Monastery are utilizing solar energy. Even if the $360 \mathrm{~m}^{2}$ of solar collectors of the Monastery were well integrated in the roof and façade, they would be quite visible on the building. Since it was possible to place the collectors on the roof and the façades of the inner rooms of the building which are not visible from the outside, the installation was approved by the National Heritage Agency. The collectors were fabricated specially for this project. For aesthetic reasons, so-called blind collectors (dummies without absorbers) were installed to some extent.

Table 11 Renewable/heating installations in historic and protected buildings

\begin{tabular}{|l|c|c|c|}
\hline & Solar & Other renewables & Other Heating source \\
\hline Osram Culture Centre (DK) & $1 \mathrm{~kW}_{\mathrm{p}}$ PV + Solar heating & & District heating \\
\hline NVE office building (NO) & & & District heating \\
\hline Kaiserstrasse 7, Vienna (AT) & & & District heating \\
\hline Kampen School (NO) & & & oil + el \\
\hline Franciscan Monastery (AT) & $360 \mathrm{~m}^{2}$ solar thermal collectors & Heat pumps $(200 \mathrm{~kW})$ & District heating \\
\hline
\end{tabular}

Table 12 summarizes the technical installations in the buildings. Three of the buildings implemented measures to improve the lighting conditions by enhancing the use of daylight, and by installing energy efficient lighting with daylight control.

Table 12 Technical systems in historic and protected buildings

\begin{tabular}{|l|l|l|l|}
\hline & \multicolumn{1}{|c|}{ Lighting } & \multicolumn{1}{|c|}{ Cooling } & \multicolumn{1}{c|}{ Ventilation system } \\
\hline Osram Culture Centre (DK) & Enhanced use of daylight. & & $\begin{array}{l}\text { Mechanical ventilation with heat } \\
\text { recovery + natural ventilation via roof } \\
\text { windows (controlled by electrical } \\
\text { motors base on indoor climate) }\end{array}$ \\
\hline NVE office building (NO) & $\begin{array}{l}\text { Energy efficient lighting } \\
\text { with daylight control. }\end{array}$ & $\begin{array}{l}\text { Active cooling in parts of } \\
\text { the building. }\end{array}$ & VAV, 81-82 \% heat recovery. \\
\hline Kaiserstrasse 7, Vienna (AT) & $\begin{array}{l}\text { Energy efficient lighting } \\
\text { with movement sensor. } \\
\text { Enhanced use of daylight. }\end{array}$ & Nighttime ventilation. & $\begin{array}{l}\text { Mech. Ventilation with heat recovery } \\
\text { in 2.nd and 3.rd floor and attic. }\end{array}$ \\
\hline Kampen School (NO) & & & $\begin{array}{l}\text { Ventilation system only in the event } \\
\text { temperature) }\end{array}$ \\
\hline Franciscan Monastery (AT)
\end{tabular}


The Norwegian Energy Authority building installed a VAV-system with a $82 \%$ heat recovery rate. The building's thermal mass is used to moderate temperature variations to reduce heating and cooling demand. Decentralized water heaters are installed on each floor, and district heating is supplying the building with heat. The air intake for ventilation is placed through ground ducts to improve heat recovery.

Mechanical ventilation with highly efficient heat recovery system was installed in the Osram building in combination with the natural ventilation controlled by the automatic opening system. More windows were added to increase the amount of daylight in the building, and low energy lighting was installed. The original heating system with district heating using steam supply was replaced with a new district heating system using hot water. Thermostat valves were installed on the radiators. A solar heating system was installed to supplement the district heating. There are plans to add $4.8 \mathrm{~m}^{2} \mathrm{PV}$ panels, but these are not installed yet.

The Kaiserstrasse 7 in Vienna had no mechanical ventilation before the renovation. During the renovation, a mechanical ventilation system with heat recovery was installed in the 2 nd, the 3 rd floor and the attic. The original heating system was district heating and radiators. After the renovation, radiators were installed in the lower floors and floor heating in the upper floors. The hot water supply was central, now it is central for the lower floors, and decentralized for the upper floors.

In Kampen School in Oslo a LCC-analysis showed that hybrid ventilation was the most economically beneficial system. No mechanical cooling was installed except for the nighttime ventilation. The ventilation system is a demand-controlled displacement system with combined $\mathrm{CO}_{2}$ and temperature sensors. Due to the renovation, the daylight utilization increased using shelves on the inside of the window to reflect the sunlight deeper into the room. An energy-efficient lighting system with movement sensors was also installed. The radiators were updated with thermostatic valves to improve energy control.

The heating system in Franciscan Monastery was changed from a high-temperature to low temperature system (component heating and radiators with individual room thermostat control). There was no cooling system installed and only mechanical ventilation in the events room. $180 \mathrm{~m}^{2}$ roof-integrated flat-plate collectors were installed on the south wing, and $180 \mathrm{~m}^{2}$ of the façade collectors. The collectors supply hot water to warm the walls and to preheat the well water used in the two heat pumps. The heated water is stored in three tanks with a capacity of 15,000 liters. As the monastery walls can store a great deal of heat, the inflow temperature is a mere 32 to $33^{\circ} \mathrm{C}$. Two heat pumps ( $200 \mathrm{~kW}$ each, with solar preheating) can deliver any additional energy required for heating and hot water supply. Finally, the monastery is connected to the district heating system for a backup. 


\subsection{Energy}

Table 13shows the reduction in reported energy use for the historic and protected buildings.

Table 13 Energy use in historic and protected buildings [kWh/m2]

\begin{tabular}{|l|c|c|c|l|}
\hline & \multicolumn{2}{|c|}{ Total Energy } & & \multicolumn{1}{|c|}{ Comment } \\
\hline & Before & After & $\%$ red & \\
\hline Osram Culture Centre (DK) & 288 & 153 & $47 \%$ & $\begin{array}{l}\text { Primary energy consumption, including electricity (+ } \\
\text { appliances), DHW and heating. Calculated. }\end{array}$ \\
\hline NVE office building (NO) & 213 & 119 & $44 \%$ & $\begin{array}{l}\text { Before: Measured, including appliances. } \\
\text { After: Overall, demand of energy. Calculated. }\end{array}$ \\
\hline Kaiserstrasse 7, Vienna (AT) & 64 & 27 & $58 \%$ & Primary energy. \\
\hline Kampen School (NO) & 281 & 151 & $46 \%$ & Net energy use. Measured \\
\hline Franciscan Monastery (AT) & 183 & 85 & $54 \%$ & Energy performance certificate calculations \\
\hline
\end{tabular}

The Norwegian Energy Authority building is the first listed building in Norway to be upgraded to Energy label $B$. The net space heating demand after renovation is calculated to $36 \mathrm{kWh} / \mathrm{m}^{2}$. The tenants accepted more hours with the temperature above $26^{\circ} \mathrm{C}$.

In the Osram building the heat demand was reduced from 158 to $37 \mathrm{kWh} / \mathrm{m}^{2}$, a reduction of $63 \%$. The total energy savings are9,500 kWh of electricity and 181,000 kWh of heat.

The calculated primary energy demand for Kaiserstrasse 7 in Vienna is reduced from $64 \mathrm{kWh} / \mathrm{m}^{2}$ to about $27 \mathrm{kWh} / \mathrm{m}^{2}$. Even when additional electricity for the ventilation fans was needed, the primary energy demand was reduced. The heat energy demand was reduced by $80 \%$.

The energy savings for the Kampen School in Oslo have been achieved through the installation of thermostatic valves on the radiators, use of natural driving forces and reduced fan power for ventilation, demand-controlled ventilation with heat recovery, and demand-controlled lighting and maximum use of day lighting.

For the Franciscan Monastery the energy systems are not yet performing satisfactorily, and a monitoring evaluation has not yet been possible. The given energy numbers represent therefore the calculated results. The calculated result corresponds to a reduction of $54 \%$.

\subsection{Economy}

The Osram Culture Centre and the Franciscan Monastery have provided data about the costs related to the energy savings and innovative measures. The costs given for the NVE office building are the total renovation cost. The reason behind the high costs here can be the listing of the NVE building as a historic building. The work was done in close cooperation with the Directorate for Cultural Heritage to keep focus on existing qualities. 
Table 14 Renovation costs historic and protected buildings

\begin{tabular}{|c|c|c|c|}
\hline & Euro $/ \mathrm{m}^{2}$ & Comment & Public funding \\
\hline Osram Culture Centre (DK) & 216 & $\begin{array}{l}\text { Investment related to energy } \\
\text { savings. Total investment: } \\
575 \text { Euro/m2 }\end{array}$ & $\begin{array}{l}\text { Copenhagen Energy Pool, Pool for } \mathrm{CO} 2 \text { neutrality in } \\
\text { existing city districts, Urban renewal funds, Accessibility } \\
\text { pool }\end{array}$ \\
\hline NVE office building (NO) & 1185 & Total renovation cost & $\begin{array}{l}\text { Financial support from ENOVA (public enterprise for state } \\
\text { funding) }\end{array}$ \\
\hline Kampen School (NO) & n.a & & \\
\hline Franciscan Monastery (AT) & n.a & & \\
\hline
\end{tabular}

The renovation of the Norwegian Energy Authority building had a total cost of a little less than $20 \mathrm{M} €$ ex VAT, i.e. $1,185 € / \mathrm{m}^{2}$. The project received financial support from the government for converting from direct electrical heating to district heating.

For the renovation of the Osram building, the total cost was $1.5 \mathrm{M} €$, the cost related to energy savings was $212,000 €$. The expected total annual saving was $13,000 €$. The project received public funding from several institutions and initiatives.

The renovation project of Kaiserstrasse 7 in Vienna had a total cost of 763,532 $€$. This is the total cost of the innovative measures. The project have been implemented through funding by the federal research program "building of tomorrow". The project was included as a demonstration project in the lead-project "Gründerzeit mit Zukunft "which deals specifically with the renovation of historical buildings (before 1919).

The hybrid ventilation (HV) solution in Kampen School was compared with the traditional mechanical balanced ventilation (MBV). The investment cost was about 10\% higher for the HV than the MBV, but the Life Cycle Cost (LCC) was about $15 \%$ lower for the HV. The HV was chosen based on the LCC analysis. The renovation received a public grant of 70,600 $€$ for the R\&D activities. The contractor was chosen through an open tender.

For the Franciscan Monastery there are no available data on costs. 


\subsection{Environment}

There have been reported different environmental measures and results for the four buildings.

Table 15 Environmental indicators in historic and protected buildings

\begin{tabular}{|c|c|c|c|c|c|c|}
\hline & $\begin{array}{l}\text { Improved } \\
\text { lighting } \\
\text { quality }\end{array}$ & $\begin{array}{l}\text { Improved } \\
\text { indoor } \\
\text { thermal } \\
\text { climate }\end{array}$ & $\begin{array}{l}\text { Improved } \\
\text { air } \\
\text { quality }\end{array}$ & $\begin{array}{c}\text { Better } \\
\text { acoustics }\end{array}$ & $\begin{array}{c}\text { Environmental } \\
\text { classified }\end{array}$ & Materials \\
\hline Osram Culture Centre (DK) & $\mathrm{x}$ & $\mathrm{x}$ & $x$ & & & \\
\hline NVE office building (NO) & & & & & Energy label B & $\begin{array}{l}\text { Reuse, environmental } \\
\text { certified materials, all } \\
\text { new wood from } \\
\text { sustainable forestry. }\end{array}$ \\
\hline Kaiserstrasse 7, Vienna (AT) & & & & & $\begin{array}{l}\text { Total Quality } \\
\text { Building } \\
\text { Certificate (TQB) }\end{array}$ & \\
\hline Kampen School (NO) & $\mathrm{x}$ & $x$ & $\mathrm{x}$ & & & \\
\hline Franciscan Monastery (AT) & $x$ & $x$ & & & & Reuse of materials. \\
\hline
\end{tabular}

In the renovation of the Norwegian Energy Authority building the existing teak doors were reused (as new doors or material components). The project has a good environmental profile on all new materials; documentation through BASS and environmentally certified products was used in the interior design and the furniture. All wood came from the sustainable forestry and there was no use of the new tropical wood. Minimum $30 \%$ recycled aluminum and $50 \%$ recycled steel was used. Water saving sanitary equipment was installed, and minimum $85 \%$ of building waste was to be separated on site.

The indoor climate of the Osram building was improved significantly by the renovation process. Daylight levels in the building were raised by introducing roof windows. The general lighting system is fitted with automatic control so that the electric lighting depends on the daylight levels in the building. The insulation of the building envelope along with the installation of the new windows increased the thermal comfort in the building. The increase in the air tightness and the removal of the cold areas (windows and walls) helped to remove draught and general discomfort in the building. Another important aspect of the building renovation is the improved lay-out of the building and the

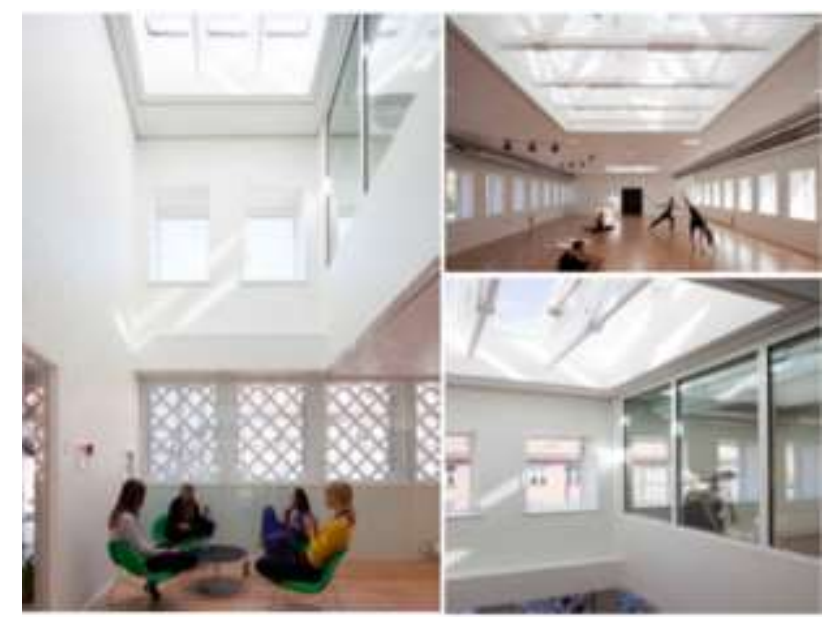

Figur 24 The roof windows have a significant and positive influence on the daylighting level in the building flexibility with which the building can now be used. The improved indoor climate also helped to make the entire building area useable. 
The Kaiserstrasse $\mathbf{7}$ in Vienna is going to receive a certificate for the sustainable building (TQB). Main criteria of the certificate cover energy performance, ecological materials and life-cycle cost. The indoor climate of the residences and energy consumption as well as hot water demand is monitored and evaluated in a two-year period. There is planned a social evaluation of satisfaction in autumn 2014.

The Kampen School in Oslo was followed up by a R\&D project, which did several measurements on indoor climate. Temperature, $\mathrm{CO}_{2}$, lux and humidity were measured before and after the renovation. The pupils at the school answered a questionnaire. The R\&D project documented a significant improvement in the concentration and health and well-being of the pupils.

The entire renovation of the Franciscan Monastery was motivated by the energy and environmental optimization. The number of new materials was limited as much as possible. The indoor climate was significantly improved by the component heating, but there are no measured values available. Conscious use of lighter materials in the interior design is friendlier with regards to lighting.

\subsection{Decision process}

The Norwegian Energy Authority renovation idea was born in 2008 and a detailed project description was completed in August 2009. The renovation work started January 2010. The energy target was upgraded from class C to B during the project period. The renovation was completed in May 2011.

The intention of the Osram building renovation project was to transform the former industry building to a culture center, and to use the energy project as an example and inspiration for the local community. The daily users and the local administration of "OSRAM" were deeply involved in the designing of the renovation project. The renovation is also a part of a strategic cooperation with the purpose of mutual profiling of climate friendly buildings, initiated by the City of Copenhagen in connection with the Climate Change Conference in Copenhagen in 2009 (COP15 2009).

Main incentives for the renovation of the Kaiserstraße $\mathbf{7}$ in Vienna were the required renovation of the façade as well as the wish to improve comfort levels and reduce energy consumption.

The idea of renovating Kampen School was born in 2000, and a detailed project description was completed in 2002. The renovation was completed in July 2003, and the effects of the improved indoor air quality were evaluated in 2001-04.

The brothers in the Franciscan Monastery together with the architect Michael Lingenhöle were working on the master plan from 2001 to 2007. It was named "Ort der Begegnung / Place to Come Together". The present value of the monastery was described, and what it should be in the future. The parts of the buildings were divided in 11 thematic priorities of the monastic work like library, culture, sacral rooms, social activities etc. Since then, the modernizing process in every part of the monastery has been implemented successively. The four level energy vision was developed based on the master plan. 


\section{List of all exemplary projects with key numbers}

The table on the next page presents some of the key numbers for all of the 20 exemplary projects.

Due to the space limitations, a number of abbreviations are used in some of the columns:

\section{Solar:}

PV - Photovoltaic

ST - Solar thermal

SC - Solar Cooling

\section{Heating:}

$\mathrm{DH} \quad$ - District heating

$\mathrm{CB} \quad$ - Condensing boilers

Bio - Biomass

HP - Heat pump

PCM - Phase Change Materials

\section{Cooling}

PC - Passive cooling

AC - Air-cooling

GTC - Geothermal cooling (wells)

NTV - Nighttime ventilation

\section{Ventilation:}

HR - Heat recovery

MV - Mechanical ventilation

NV - Natural ventilation

DC - Demand controlled

DV - Displacement ventilation 


\begin{tabular}{|c|c|c|c|c|c|c|c|c|c|c|c|c|c|c|c|c|c|c|c|c|c|}
\hline \multicolumn{6}{|c|}{ Key numbers in all exemplary projects } & \multirow{3}{*}{ है } & \multirow[b]{3}{*}{ 点 } & \multirow[b]{3}{*}{ 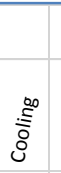 } & \multirow{3}{*}{ 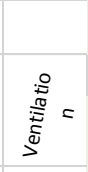 } & \multicolumn{3}{|r|}{ Energy numbers } & \multicolumn{8}{|c|}{ U-values $\mathrm{W} / \mathrm{m} 2 \mathrm{~K}$} & \multirow{3}{*}{ 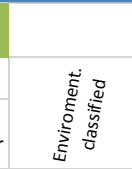 } \\
\hline & \multirow[b]{2}{*}{ 音 } & \multirow[b]{2}{*}{$\frac{\pi}{0}$} & \multirow[b]{2}{*}{ 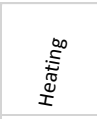 } & \multirow{2}{*}{ 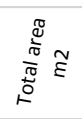 } & \multirow[b]{2}{*}{$\begin{array}{l}\text { है } \\
\text { 离 }\end{array}$} & & & & & \multicolumn{2}{|c|}{ Total Energy } & \multirow[t]{2}{*}{ Comment } & \multicolumn{2}{|c|}{ Floor } & \multicolumn{2}{|c|}{ Roof } & \multicolumn{2}{|c|}{ Walls } & \multicolumn{2}{|c|}{ Windows } & \\
\hline & & & & & & & & & & Before & After & & Before & After $\mathrm{E}$ & Before & After $\mathrm{E}$ & Before & After & Before & After & \\
\hline \multicolumn{22}{|l|}{ Education buildings } \\
\hline Kindergarden Vejtoften (DK) & 1971 & & $\mathrm{DH}$ & 350 & 64 & $\begin{array}{l}\text { Ekstra cost renovating envelope to low } \\
\text { energy standard. Total cost } 575 € / \mathrm{m} 2 \text {. }\end{array}$ & $\mathrm{x}$ & & $\mathrm{HR}$ & 158 & 66 & Calculated onsumption heat, DHW and Elec. & 0,34 & 0,06 & 0,65 & 0,65 & 0,45 & 0,11 & 2,6 & 0,60 & \\
\hline School of Cesena (IT) & 1965 & PV & CB & 6420 & 120 & & $\mathrm{x}$ & PC & $\mathrm{MV}, \mathrm{HR}$ & 154 & 32 & $\begin{array}{l}\text { EP - index (not incl. IT and lighting) - EP - index- } \\
\text { calculated results. El from PV system included. }\end{array}$ & 2,31 & 0,19 & 2,32 & 0,28 & 1,85 & 0,30 & 5,7 & 1,14 & \\
\hline $\begin{array}{l}\text { School in Schwanenstadt } \\
\text { (AT) }\end{array}$ & 1965 & PV & Bio & 6214 & 142 & $\begin{array}{l}\text { Add. costs for PH-standards and other } \\
\text { energy measures inc + expansion. }\end{array}$ & $\mathrm{x}$ & PC & MV & 143 & 34 & $\begin{array}{l}\text { Calculated delivered energy demand, primary } \\
\text { energy demand } 59,3 \mathrm{kWh} / \mathrm{m} 2 / \mathrm{y}\end{array}$ & 0,60 & 0,15 & 3,3 & 0,1 & 2,30 & 0,13 & 1,3 & 0,8 & TQB \\
\hline Riva Bella School (BE) & 1970 & & СВ & 4500 & 89 & Extra investment for energy savings & $\mathrm{x}$ & NTC & $\mathrm{HR}$ & 180 & 35 & Calculated heat demand. & 2,50 & 0,51 & 0,50 & 0,19 & 0.8 & 0,17 & 5,8 & 1,2 & \\
\hline $\begin{array}{l}\text { ASO } 4 \text { Karlhofschule Linz } \\
\text { (AT) }\end{array}$ & & ST & & & & & $\mathrm{x}$ & NTC & MV & n.a & 3,12 & Heating energy demand (energy certificate) & & & & & & & & & TQB \\
\hline \multicolumn{22}{|l|}{$\begin{array}{l}\text { Historic and protected } \\
\text { buildings }\end{array}$} \\
\hline Osram Culture Centre (DK) & 1953 & $\mathrm{PV}, \mathrm{ST}$ & $\mathrm{DH}$ & 980 & 216 & $\begin{array}{l}\text { Investment related to energy savings. } \\
\text { Total investment: } 575 € / \mathrm{m} 2\end{array}$ & $\mathrm{x}$ & - & $\begin{array}{l}\text { MV, NV, } \\
\text { HR }\end{array}$ & 288 & 153 & $\begin{array}{l}\text { Primary energy consumption, including } \\
\text { electricity (+ appliances), DHW and heating. }\end{array}$ & 1,47 & 1,47 & 0,25 & 0,25 & 2,69 & 0,09 & 4,3 & 0,9 & \\
\hline NVE office building (NO) & 1964 & & $\mathrm{DH}$ & 16880 & 1185 & Total renovation cost & $\mathrm{x}$ & $A C$ & $\mathrm{MV}, \mathrm{HR}$ & 213 & 119 & $\begin{array}{l}\text { Before: mesaured, including appliances. After: } \\
\text { Calculated overall demand of energy }\end{array}$ & 0,15 & 0,15 & 0,95 & 0,2 & 0,57 & 0,41 & 2,5 & 1,3 & Energy label B \\
\hline Kaiserstrasse 7, Vienna (AT) & 1904 & & $\mathrm{DH}$ & & 213 & Total costs of the innovative measures & & & $\mathrm{MV}, \mathrm{HR}$ & 64 & 27 & Primary energy & 1,07 & 1,07 & 0,90 & 1,16 & 0,92 & 0,44 & 2,2 & 0,90 & TQB \\
\hline Kampen School (NO) & 1888 & & oil +el & 4500 & n.a & & $\mathrm{x}$ & NTV & $\mathrm{DC}$ & 281 & 151 & Net energy use, measured & & & & & & & & & \\
\hline Franciscan Monastery (AT) & $\begin{array}{c}1239- \\
1550\end{array}$ & ST & HP & 3585 & 213 & & & & MV & 183 & 85 & Energy performance - delivered? & 0,77 & 0,18 & & 0,18 & 1,05 & 0,30 & 2,5 & 1,30 & \\
\hline \multicolumn{22}{|l|}{ Office buildings } \\
\hline $\begin{array}{l}\text { Tax Directorate Office } \\
\text { Building (NO) }\end{array}$ & 1980 & & $\mathrm{DH}$ & 35119 & 116 & $\begin{array}{l}\text { Extra cost for PH standard, subzidizes } \\
\text { not included }\end{array}$ & $\mathrm{x}$ & AC & MV & 174 & 88 & $\begin{array}{l}\text { Total net energy demand (incl. Appliances). } \\
\text { Calculated. }\end{array}$ & & & 0,50 & 0,12 & 0,30 & 0,17 & 1,8 & 0,72 & BREEAM \\
\hline Powerhouse Kjørbo (NO) & 1980 & PV & HP & 5180 & 2654 & Not public & $\mathrm{x}$ & $A C$ & $\begin{array}{l}\text { DV, HR, } \\
\text { NV }\end{array}$ & 210 & 20,4 & $\begin{array}{l}\text { Annual delived energy, without data and } \\
\text { technical equipment. Calculated. }\end{array}$ & & & 0,20 & 0,08 & 0,30 & 0,08 & 1,8 & 0,80 & BREEAM \\
\hline $\begin{array}{l}\text { Office and Workshop } \\
\text { Building Fraunhofer ISE (DE) }\end{array}$ & 1975 & & DH & & & $\begin{array}{l}432,000 € \text { are cost for insulation, } \\
\text { windows and ventilation }\end{array}$ & & NTV & $\mathrm{MV}, \mathrm{HR}$ & n.a & 337 & Primary energy use. Calculated. & & & 1,80 & 0,41 & 1,80 & 0,41 & 2,4 & 1,20 & \\
\hline $\begin{array}{l}\text { Printing workshop and } \\
\text { office building (DE) }\end{array}$ & 1978 & & $\mathrm{HP}+\mathrm{PCM}$ & 1100 & 1097 & Cost of construction + HVAC & $\mathrm{x}$ & GTC & $\mathrm{MV}, \mathrm{HR}$ & 320 & 135 & Heating, cooling, ventilation and lighting & & & 0,50 & 0,19 & 2,60 & 0,30 & 2,7 & 1,40 & \\
\hline TU Vienna Plus Energy (AT) & 1970 & PV & $\begin{array}{c}\mathrm{DH}+ \\
\text { El.boiler }\end{array}$ & 7670 & 2738 & Tot. Cost of renovation & $\mathrm{x}$ & $A C$ & $\mathrm{MV}, \mathrm{HR}$ & 358 & 36 & $\begin{array}{l}\text { Energy consumption, not included energy } \\
\text { production from PV }(29 \mathrm{Wh} / \mathrm{m} 2 / \mathrm{y}) \text {. Calculated. }\end{array}$ & 0,90 & 0,12 & 0,60 & 0,07 & 0,70 & 0,09 & 2,5 & 0,62 & TQB \\
\hline Office Building Roskilde (DK) & 1968 & PV & DH & 2478 & 1932 & Cost of renovation & $\mathrm{x}$ & $A C$ & $\mathrm{MV}, \mathrm{HR}$ & & 112 & $\begin{array}{l}\text { Heat and DHW use+ el including PV. Total } \\
\text { energy use incl. Aux and printing room, }\end{array}$ & & & 0,20 & 0,10 & 0,30 & 0,14 & 2,6 & 1,00 & \\
\hline Schüco Headquarter (IT) & 1990 & $\begin{array}{c}\mathrm{PV}, \mathrm{ST}, \\
\mathrm{SC}\end{array}$ & $\mathrm{HP}+\mathrm{CB}$ & 4311 & 1120 & Total cost of renovation & $\mathrm{x}$ & SC & $\mathrm{MV}$ & 97 & 61 & Heat in primary energy. Calculated. & & & 1,48 & 0,3 & 1,25 & 0,38 & 4,0 & 1,6 & \\
\hline $\begin{array}{l}\text { Rockwool office building } \\
\text { (DK) }\end{array}$ & 1979 & PV, ST & HP & 3626 & 1302 & $\begin{array}{l}\text { Costs energy measures, total cost } 2 \\
242 € / \mathrm{m}^{2}\end{array}$ & $\mathrm{x}$ & $A C$ & $\mathrm{MV}, \mathrm{HR}$ & 264 & 41 & Primary energy, incl. extension. Calculated. & 0,17 & 0,06 & 0,14 & 0,14 & 0,17 & 0,08 & 2,4 & 0,8 & $\begin{array}{l}\text { Energy label } \\
\text { A. EEC-ECO }\end{array}$ \\
\hline $\begin{array}{l}\text { Solbraaveien office centre } \\
\text { (NO) }\end{array}$ & $1980-82$ & & HP & 10536 & 1367 & Total cost of renovation & $\mathrm{x}$ & $A C$ & MV & 204 & 64 & Total net energy. Calculated. & & & 0,20 & 0,13 & 0,27 & 0,16 & 2,6 & 0,9 & \\
\hline $\begin{array}{l}\text { Administration Building } \\
\text { Bruck/Mur (AT) }\end{array}$ & 1964 & PV, PS & DH (bio) & 853 & n.a & & $\mathrm{x}$ & GTC & $\mathrm{MV}, \mathrm{HR}$ & 153 & 24 & $\begin{array}{l}\text { Heating demand. Prim. Energy demand reduced } \\
\text { by } 65 \% \text {. Calculated. }\end{array}$ & & & 1,05 & 0,11 & 2,11 & 0,16 & 2,5 & 1,2 & \\
\hline
\end{tabular}




\section{Appendix}

\section{Task 47 Glossary and terms}

Updated: 06.11.2012

The origin of the terms is shown in brackets. Most of the energy definitions below are taken from the European EN 15603:2008.

\section{ENERGY}

Primary energy PE [kWh] (EN 15603:2008)

Energy that has not been subjected to any conversion or transformation process.

Notes:

- Primary energy includes non-renewable energy and renewable energy. If both are taken into account it can be called total primary energy.

- For a building, it is the energy used to produce the energy delivered to the building. It is calculated from the delivered and exported amounts of energy carriers, using conversion factors.

- From Task 47 template: Primary energy consumption is defined as delivered energy multiplied with primary energy factors

Delivered energy [kWh] (EN 15603:2008 / ISO 13790))

Energy, expressed per energy carrier, supplied to the technical building systems through the system boundary, to satisfy the uses taken into account (heating, cooling, ventilation, domestic hot water, lighting, appliances etc.) or to produce electricity.

Notes:

- For active solar and wind energy systems, the incident solar radiation on solar panels or collectors or the kinetic energy of wind is not part of the energy balance of the building. It is decided at national level if renewable energy produced on site is part of the delivered energy.

- Delivered energy can be calculated for defined energy uses or it can be measured.

- Delivered energy is sometimes referred to as "site energy" and "purchased energy".

\section{Exported energy (EN 15603:2008)}

Energy, expressed per energy carrier, delivered by the technical building systems through the system boundary and used outside the system boundary.

Notes:

- It can be specified by generation types (e.g. CHP, PV, etc) in order to apply different weighting factors.

- Exported energy can be calculated or it can be measured.

\section{Net delivered energy (EN 15603:2008)}

Delivered minus exported energy, both expressed per energy carrier.

Notes:

- A balance of the delivered and exported energy per energy carrier can be performed only if the same primary energy factors and/or CO2-coefficients apply to the delivered and exported amounts of that energy carrier.

- The term "net" can also be applied to quantities derived from net delivered energy, e.g. primary energy or CO2 
Total primary energy factor (EN 15603:2008)

For a given energy carrier, non-renewable and renewable primary energy divided by delivered energy, where the primary energy is that required to supply one unit of delivered energy, taking account of the energy required for extraction, processing, storage, transport, generation, transformation, transmission, distribution, and any other operations necessary for delivery to the building in which the delivered energy will be used.

Note:

- The total primary energy factor always exceeds unity.

\section{Embodied energy [MJ/kg product] (Wikipedia)}

Embodied Energy is the sum of all the energy required to produce goods or services, considered as if that energy was incorporated or 'embodied' in the product itself.

Note:

- A product that requires large amounts of energy to obtain and process the necessary raw materials or a product that is transported long distances during processing or to market, will have a high embodied energy level.

Grey energy [MJ/kg product] (IEA SHC Task 47 subtask D)

Grey energy is the energy required by all the transformations undergone by a product throughout its life cycle.

Notes:

- Grey energy is the energy stored in materials and theoretically recoverable at the end of life + the energy used in operations of processing, operating and transportation over its life cycle.

Auxiliary energy [kWh] (EN 15602:2008 / ISO 13790))

Electrical energy used by technical building systems for heating, cooling, ventilation, and/or domestic water to support energy transformation to satisfy energy needs.

Notes:

- This includes energy for fans, pumps, electronics, etc. Electrical energy input to the ventilation system for air transport and heat recovery is not considered as auxiliary energy, but as energy use for ventilation.

- In EN ISO 9488, Solar Energy - Vocabulary, the energy used for pumps and valves is called "parasitic energy".

\section{AREA DEFINITIONS}

Form factor A/V [m-1] (IEA SHC Task 37 glossary)

The ratio between the building envelope area and the gross building volume.

Building envelope area $\mathbf{A}\left[\mathbf{m}^{2}\right]$ (IEA SHC Task 37 glossary)

Total external area of the building envelope enclosing the heated volume - façade (including doors and windows), roof and ground - and measured at the outer boundaries of the building.

Gross volume V [m³] (IEA SHC Task 37 glossary)

The heated building volume calculated based on the outer dimensions.

Gross floor area (DIN 277)

Total floor area of all floors of a building calculated with the external dimensions of the building including 
structures, partitions, corridors and stairs.

Note:

- From task 37 Glossary: Area which is conditioned / heated on the basis of outer dimensions

Net heated volume VN [m³ (IEA SHC Task 37 glossary)

The heated volume calculated on the basis of the internal dimensions.

Net heated floor area AN [m²] (DIN 277) ISO 9836

Sum of all areas between the vertical building components (walls, partitions ...); i.e. gross floor area reduced by the area for structural components

Note:

- Task 37 Glossary: The sum of the floor areas of all heated rooms including heated corridors and heated internal stairways but not unheated rooms.

\section{BUILDING CATEGORIES}

Net zero energy building (IEA SHC Task 37 Glossary)

A building where the net energy consumed over a year is matched by an equal amount of energy produced on site.

Zero emission building (IEA SHC Task 37 Glossary)

A building without energy generation related $\mathrm{CO} 2$ emissions.

Net zero emission building (IEA SHC Task 37 Glossary)

A building with $\mathrm{CO} 2$ emissions that are balanced over the course of the year. Consumption related $\mathrm{CO} 2$ emissions are counterbalanced by energy generation based on renewable energy. This is possible on-site and off-site.

Passive House (Passive House Institute in Germany)

According to the definition provided by the Passive House Institute in Germany, the following requirements have to be fulfilled: a maximum end-energy space heating, demand of $15 \mathrm{kWh} / \mathrm{m}^{2} \mathrm{a}$, a primary energy demand for all end-uses including electricity for appliances which is not higher than $120 \mathrm{kWh} / \mathrm{m}^{2} \mathrm{a}$, and an air-tightness of the envelope of 0.6 by $50 \mathrm{~Pa}$ overpressure.

Notes:

- There are several national varieties to this standard

Low energy building (IEA SHC Task 37 Glossary)

Buildings with the explicit intention of using less energy than standard buildings. However, no specific requirements are defined. Norway: NS3700: Buildings using 25\% less energy than the standard building code.

Plus energy building (IEA SHC Task 37 Glossary)

A building where more primary energy is produced annually than consumed. Typically, a net zero is reached by generating on-site electricity which has a high primary energy replacement value and can therefore be credited against thermal energy demand which has a lower primary energy factor.

\section{NZEB}

- Net zero Energy Buildings (IEA)

- Nearly Zero Energy Buildings (EU) 


\section{OTHERS}

Specific Fan Power (SFP) (Norwegian Standard NS 13779) Corresponds to DIN EN 13779 Ventilation for non-residential buildings)

SFP for buildings or complete systems is the sum of electric power needed by all fans in the air distribution system divided by the total amount of air ventilating (supply and exhaust) the building during design load period.

$S F P=\frac{\sum P}{q_{v}}$

SFP can be expressed in the following equivalent SI units:

$$
[S F P] \equiv \frac{k W}{m^{3} / s} \equiv \frac{W}{l / s} \equiv \frac{k J}{m^{3}} \equiv k P a
$$

